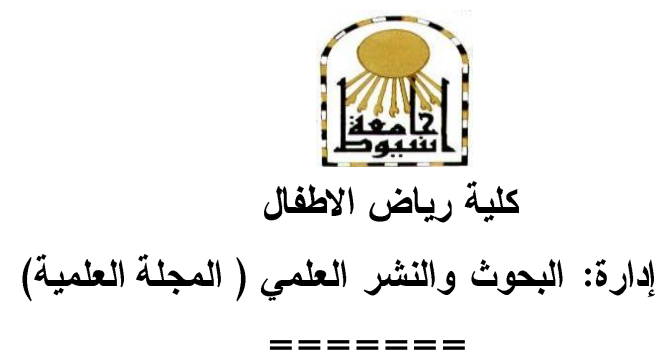

\title{
برنامج مقتزح لتدريب المعلمات على تعسين بعض اضطرابات النطق لدى أطفال الروضة
}

\author{
د/ منال أنور سيد \\ مدرس بقسم العلوم التربوية \\ كلية رياض الأطفال - جامعة أسيوط
}

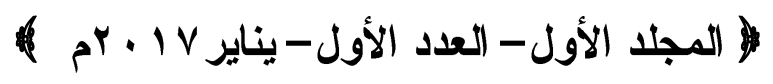




\section{المستخلص:}

هدف البحث إلى ندريب المعلمات على تحسين بعض اضطرابات النطق لدى أطفال

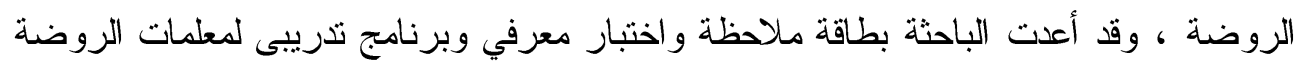

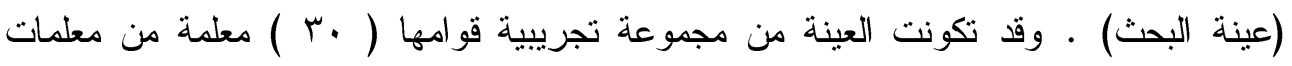

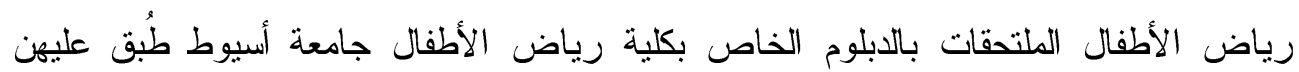

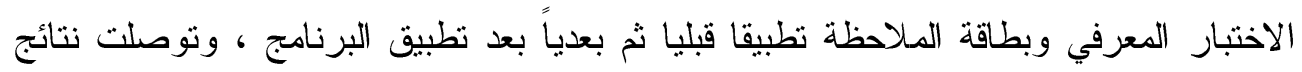

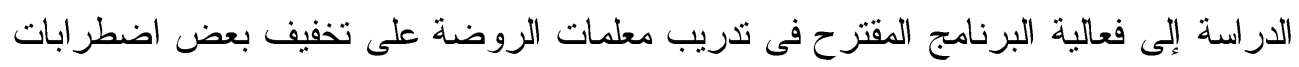

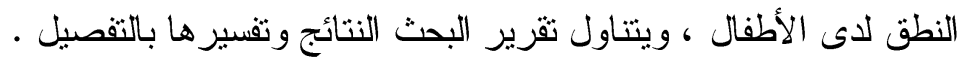
كلمات مفتاحية : معلمات الروضة ، اضطرابات النطق ، تحسين اضطر ابات النطق . 


\begin{abstract}
:
The aim of the research was to train the teachers to improve some of the speech disorders in kindergarten children. The researcher prepared a note card, a Cognitive Test and a training program for kindergarten teachers. The sample of the study consisted of (30) kindergarten teachers enrolled in the special diploma in the Faculty of Kindergarten Assiut University, where the test of Cognitive and the observation card were carried out before and after the implementation of the program. The results of the study reached the effectiveness of the proposed program in training kindergarten teachers to relieve some speech disorders in children; the study report addresses the results and explains them in detail.
\end{abstract}

Keywords: kindergarten parameters, speech disorders, speech disorders improvement. 


\section{مقدمة :}

تعد مرحلة الطفولة من أهم مراحل النمو، فهي القاعدة التي يعتمد عليها كل ما يتلوها

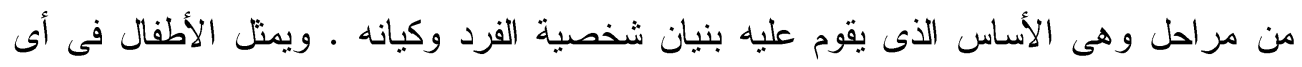
مجتمع وفى أى عصر من العصور شريحة مهمة يجب التركيز عليها والاهتمام بها ، ومن هنا لنا

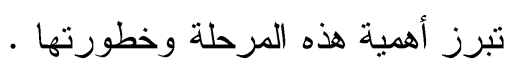

وقد يتعرض الأطفال فى هذه المرحلة لكثير من المشكلات والاضطرابات والتى يجب

علينا أن نضعها دائماً فى الاعتبار ـ وتعد مشكلات واضطرابات النطق من أكثرها انتشاراً بين الأطفال ، والتى قد تسبب مشكلات نفسية واجتماعية ، لذا فلابد من الانتباه لها و العمل على حلها

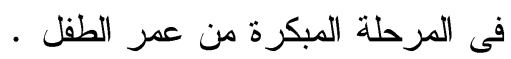

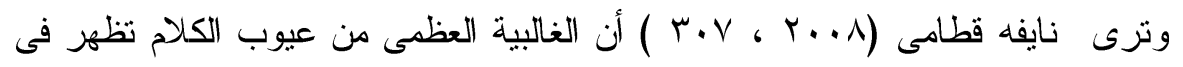
سن ما قبل الددرسة وأن الأو لاد أميل من البنات إلى تكرار هذه العيوب . وتحدث اضطر ابات النطق لدى الأطفال نتيجة أخطاء فى إخراج أصوات حروف الكلام من مخارجها ، وعدم تشكيلها بصورة صحيحة وتختلف درجات اضطرابات النطق من مجرد اللثغة البسيطة إلى الاضطراب الحاد ، حيث يخرج الكلام غير مفهوم نتيجة الحذف والإبدال

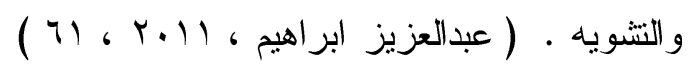

وقد ينتج عن هذه الاضطرابات والمشكلات آثار نفسية واجتماعية خطيرة إن لم نحسن

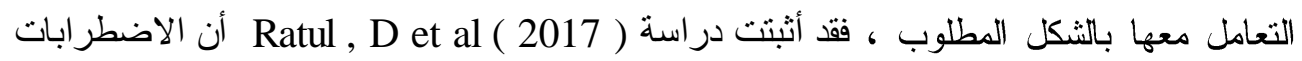
الكلامية تعيق القدرة على التواصل إلى حد مختلف وتؤثر سلبا على الاتصال الاجتماعي والعاطفي

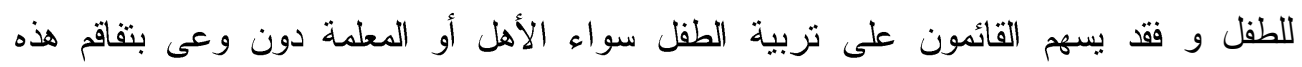

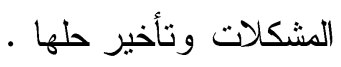

و إذا كان الطفل هو مستقبل الأمة ، فمعلمة الروضة هى صانعة هذا المستقبل ، فهى

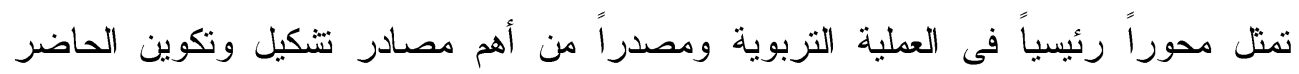

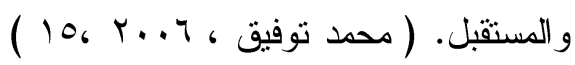




\section{المجلة العلمية لكلية رياض الاطفال - جامعة اسيوط}

واذا كانت عملية إعداد المعلم بشكل عام عملية مهمة وحيوية لتحقيق الأهداف التعليمية ،

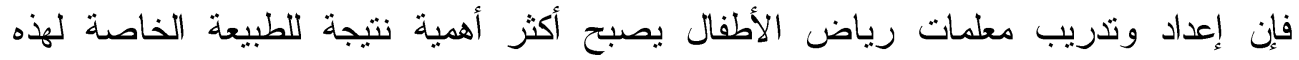
المرحلة العمرية من حياة الأطفال والمتطلبات النمائية والاجتماعية و المهارية التى تسعى المعلمة

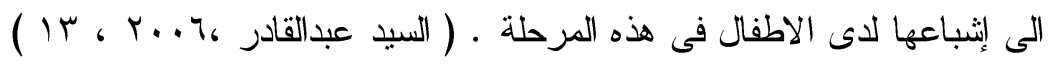

فالعبء الأكبر فى تعليم الأطفال وتحقيق أهداف الأتشطة المختلفة يقع على معلمة رياض

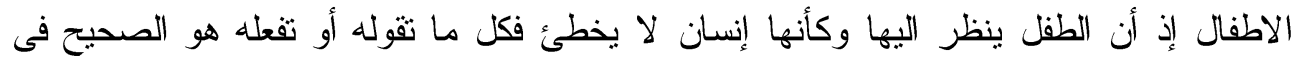

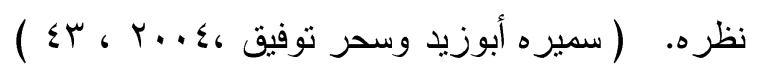

كما يقع على عاتقها العديد من المهام والأدوار و المسئوليات من أهمها تعليم الطفل كيفية نطق الحروف من مخارجها الصحيحة ومساعدته على تصحيح النطق الخاطئ وملاحظة أى لى

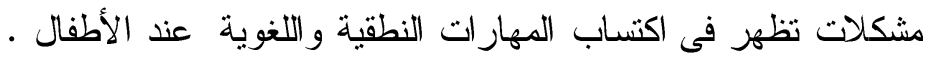

لذا يجب أن يحظى تأهيل المعلمة سواء قبل الخدمة من خلال برامج الإعداد أو من خلا الندريب أثثاء الخدمة بأهمية بالغة لما له من أثر فى مساعدتها على اكتساب المعارف والمهارات

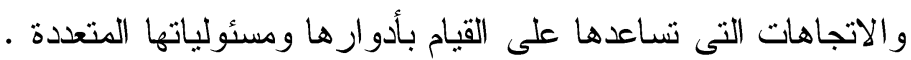

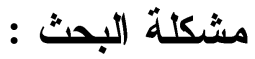

إن وجود مشكلات واضطر ابات فى النطق لدى طفل الروضة ، قد يجعله موضع سخرية

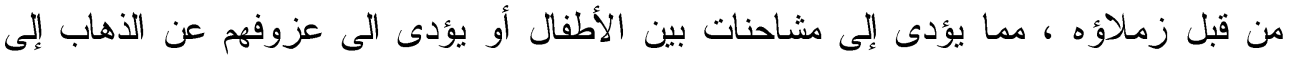

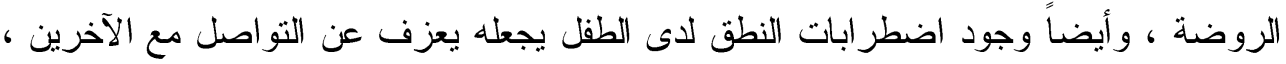

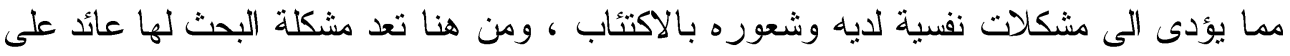

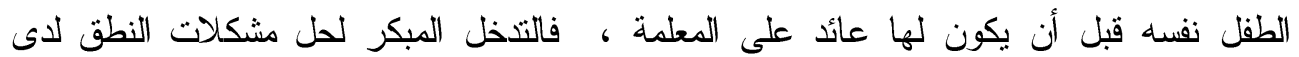

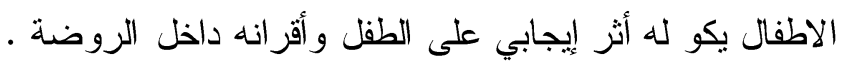

\section{وقد نبعت مشكلة البحث الحالى من :}

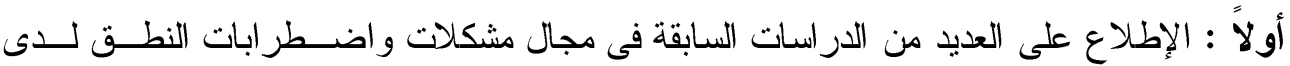

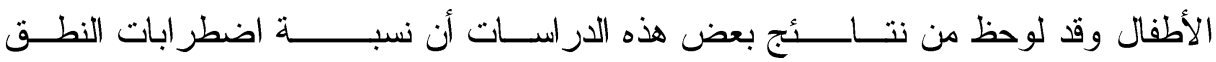

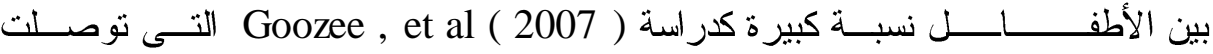

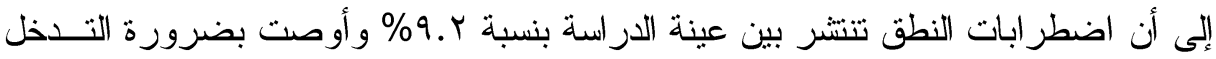




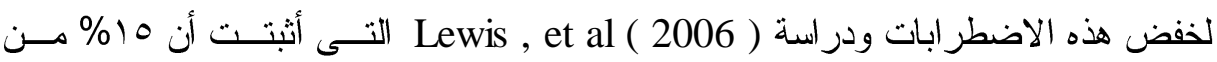

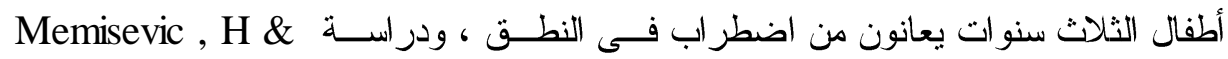
Hadzic ,S ( 2013)

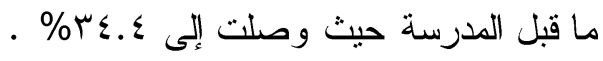
كما لوحظ أنه بالرغم من كثرة الدراسات التى تتاولت موضوع الاضطر ابات اللغوية ، فقد

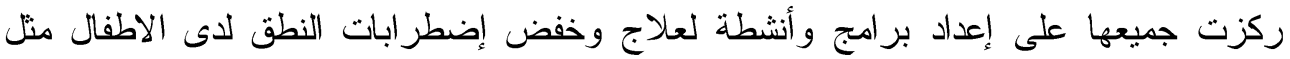

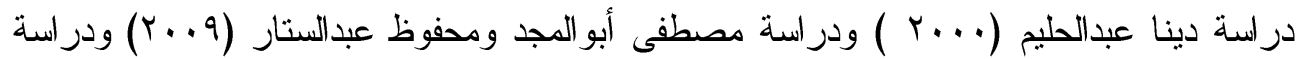

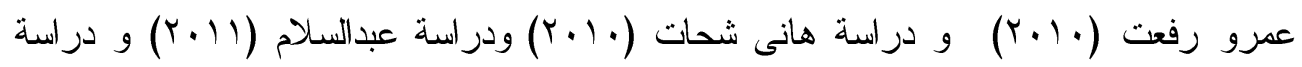

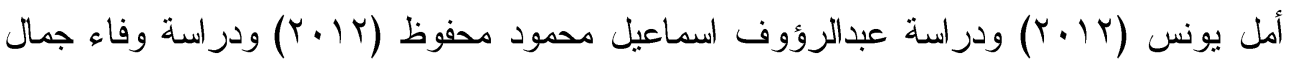

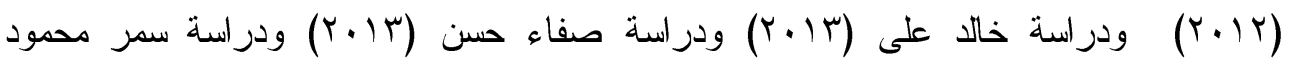

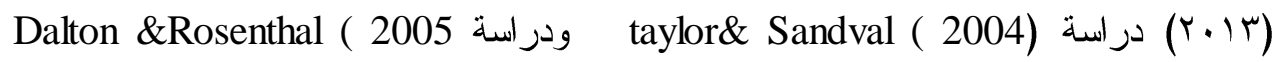

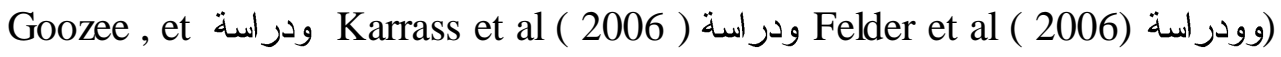
. al ( 2007 )

وذللك يشير إلى قلة الدراسات التى تتاولت تدريب المعلمات على كيفية تحسين هذه

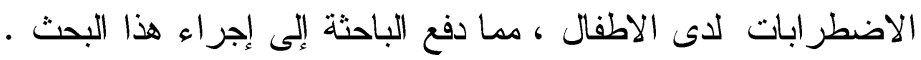
ثانياً :الملاحظة الميدانية غير المقننة من خلال تعامل الباحثة مع الأطفال والمعلمات فى التربية

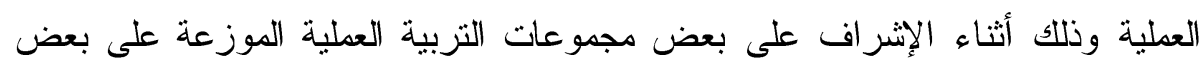
روضات محافظة اسيوط ، وقد لوحظ الآتى :

1- معاناة الكثير من أطفال الروضة من مشكلات واضطر ابات فى نطق بعض الحروف . r- قلة اهتمام المعلمات باضطرابات ومشكلات النطق التى يعانى منها بعض الأطفال واعتبارها

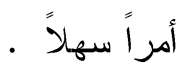
ب- إهمال أخطاء الطفل النطقية من قِيل المعلمة ( فيقول مثلاً مرضان بدلاً من رمضان ) وذلك

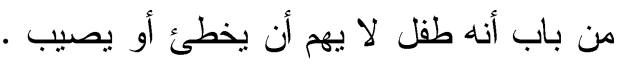


ثالثاً : قيام الباحثة باسنطلاع رأى بعض المعلمات ملحق رقم ( 1 ) وعددهن (·r) معلمة حول

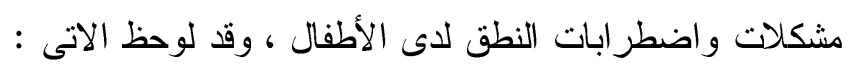

1- قصور معرفى واضح فى وعى المعلمات بالمشاكل والاضطرابات النطقية لاى أطفال الروضة .

r- تعانى المعلمات من قصور مهارى و أدائي واضح فى كيفية تحسين وحل مشكلات النطق لدى - الأطفال

ب- قلة معرفة المعلمات بالأساليب والطرق والأنشطة والتمارين التى تساعد فى تحسين عيوب

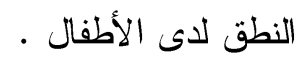

ع - أجماع المعلمات بنسبة ... 1\% من خلال استطلاع الرأي على الحاجة إلى معلومات حول

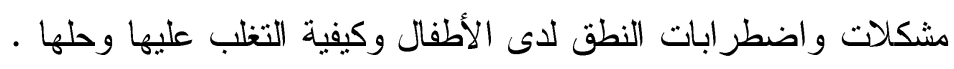
وقد جسد كل ما سبق الشعور لدى الباحثة بالحاجة إلى بناء برنامج مقترح لتنريب

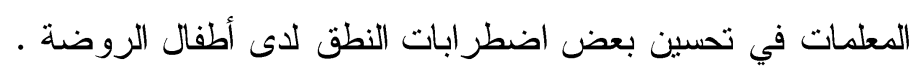
تساؤلات البحث: :

1- ما التصور المقترح لبرنامج تدريبي للمعلمات فى تحسين بعض اضطرابات النطق لدى أطفال الروضة. r- ما فاعلية البرنامج المقترح فى تدريب المعلمات على تحسين بعض اضطرابات النطق لدى

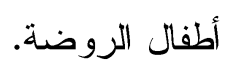
أهداف البحث : يهذف البحث الحالي إلى :

1 - إعداد برنامج تدريبي للمعلمات فى تحسين بعض اضطر ابات النطق لاى أطفال الروضة.

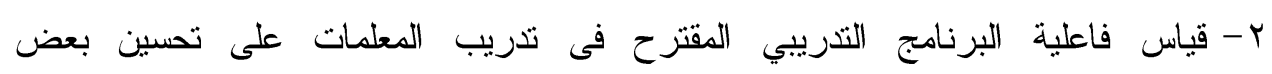

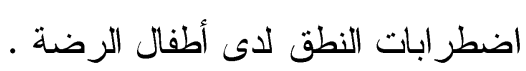




\section{أهمية البحث : (1)}

1 - تتمتل أهمية هذا البحث فى تركيزه على تدريب معلمات الروضة على كيفية تحسين بعض لـ اضطرابات النطق لدى الأطفال .

ץ- قد يفيد البحث الحالي المعلمات وأولياء الامور وجميع القائمين على تربية الطفل فى هذه

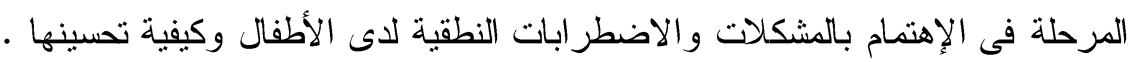

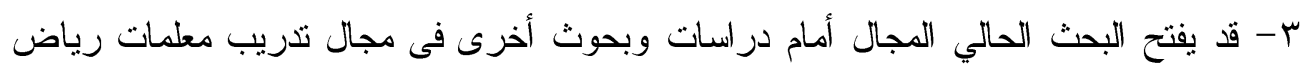

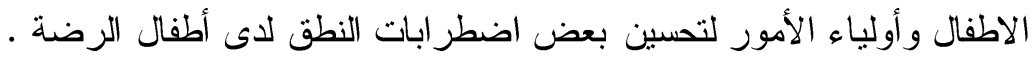

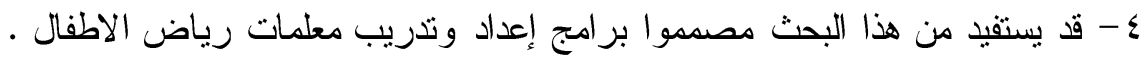

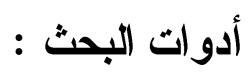

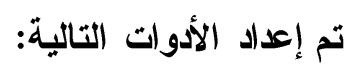
1- بطاقة ملاحظة لقياس أداء المعلمات مع أطفال الروضة ذوي اضطرات ابات النطق. r- أختبار لقياس الجانب المعرفى لدى معلمات الروضة في تحسين اضطر ابات النطق . r- برنامج تدريبي مقتر حلمعلمات في تحسين بعض اضطر ابات النطق لاى أطفال الروضة . حدود البحث :

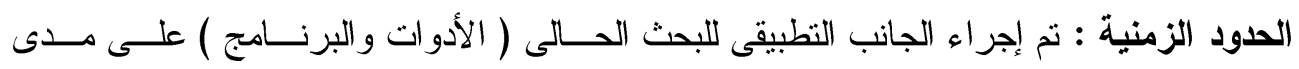

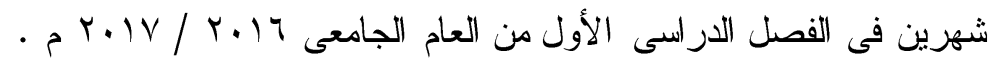

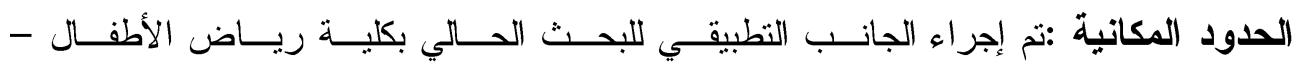
جامعة أسيوط.

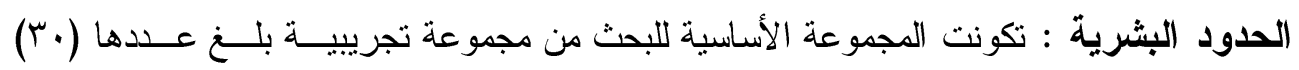

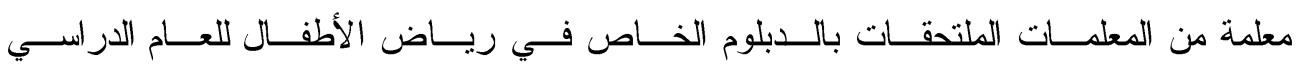

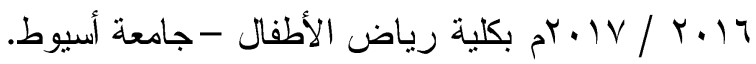

الدود الموضوعية : إقتصرت الدراسة الحالية على بعض اضطرابات النطق لـــى الأطفــال منل الحذف والإبدال و النتشويه . 
مصطات البحث : (1)

Program : البرنامـج

تعرفه فضيلة زمزمي ( 1997 ، 197 ( 197 ) على أنه تصور فكري منظم ومحدد الأهـداف

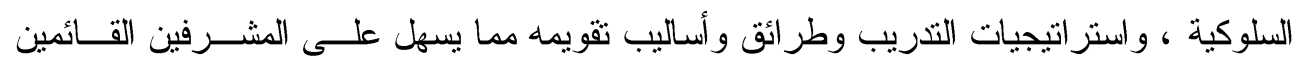

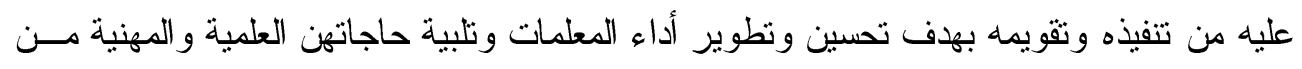

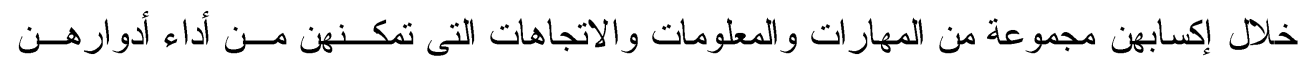

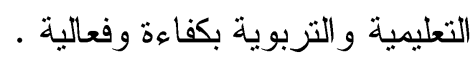

$$
\text { التعريف الإجرائي }
$$

يقصد بالبرنامج المقترح فى هذه البحث نظام متكامل العناصر مــن الأهــداف والمحتــوي

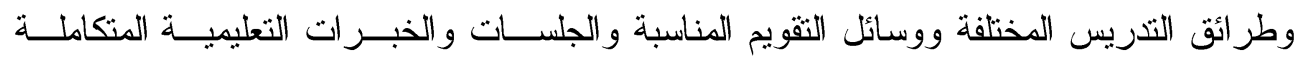
وورش العمل وذللك لتزويد المعلمات بكم من المعرفة و المعلومات المتعلقة بالاضطر ابات النطقيــة لاى الأطفال وذلك بقصد تدرييهن وتمكينهن من تحسين بعض هذه الاضطر ابات لاى الأطفال .

\section{Speech disorders : اضطر ابات النطق}

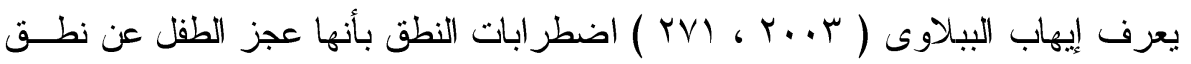

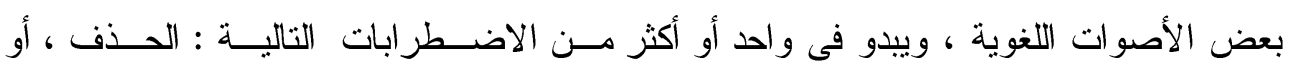

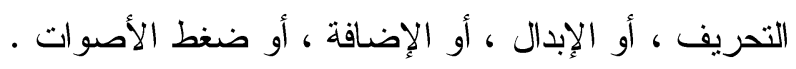

التعريف الإجرائي

تعرف اضطرابات النطق لدى الأطفال بأنها خلل فى نطق طفل الروضة لبعض الحروف

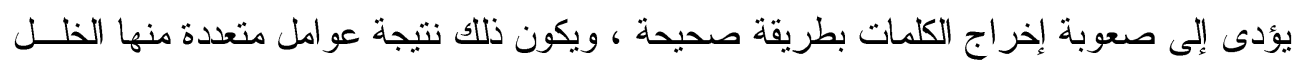
العضوى فى جهاز النطق أو عيب فى مخارج أصوات الحروف أو تقليد الطفل للآخرين ، ويبــدو هذا الاضطر اب فى واحد أو أكثر من اضطرابات الحذف ، التحريف ، الإبدال ، أو الإضافة . 


\section{الإطار النظري والاراسات السابقة :}

أولاً : تلدريب معلمات رياض الأطفال :

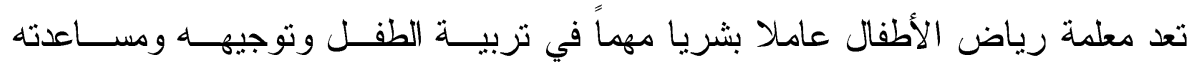

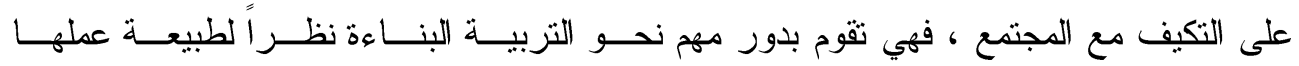

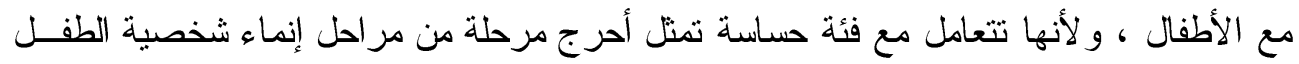

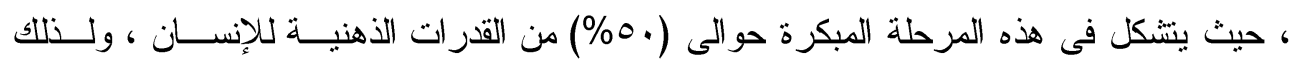

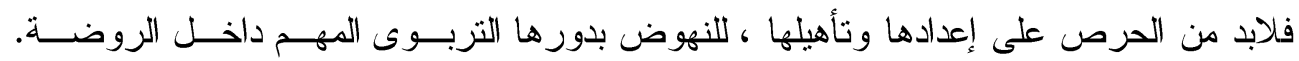

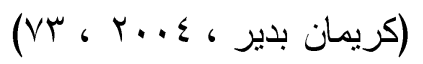

لذا فإن قضية تدريب و إعداد المعلمة وتهيئتها لمتطلبــات المهنــة ومقتضــيات العصــر

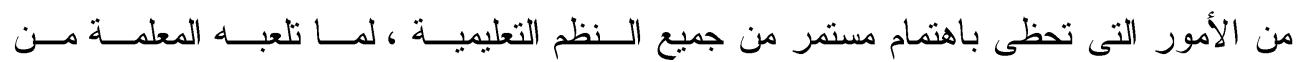

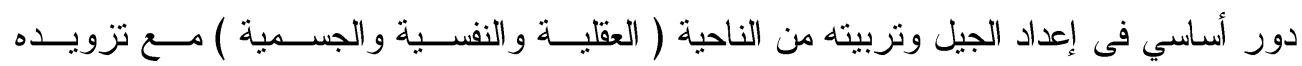
بالمعارف و المهار ات ومساعدته على التكيف مع الحياه وتوجيهه علميا وعمليا وتقــويم تعليمـهـ .

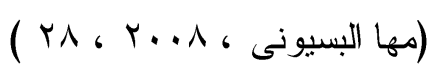

إن تدريب معلمات رياض الأطفال لم يعد قاصراً فى مفهومه المعاصر على مجرد العمـلـل

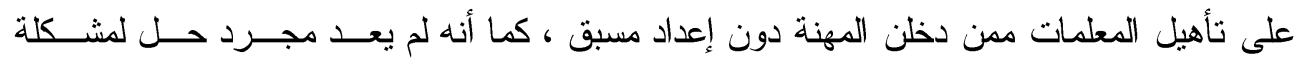
طارئة تواجه المعلمات ومحاولة الوصول إلى كيفية علاجها ، بل أصبح من الأمور الضــرورية

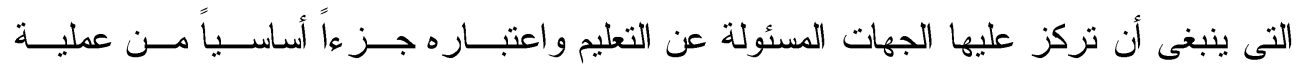

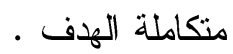

\section{أهداف تدريب معلمات رياض الأطفال : عهن :}

رفع كفاءة المعلمة وزيادة فاعليتها العلمية والمهنية بما يحسن ويطور مستوى الأداء الوظيفى

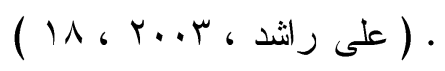

التكيف مع ظروف العمل المختلفة ، ومع الجديد من الوسائل و التقنيات المستخدمة داخـل

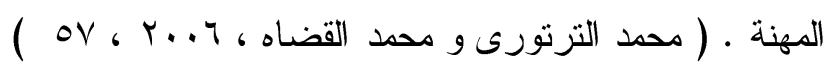

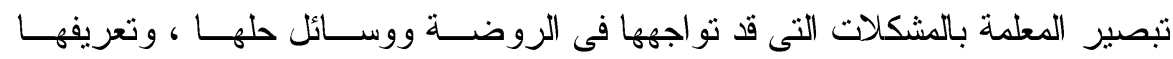

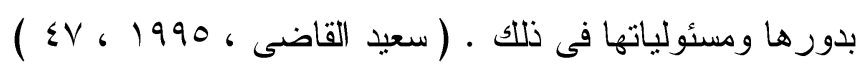

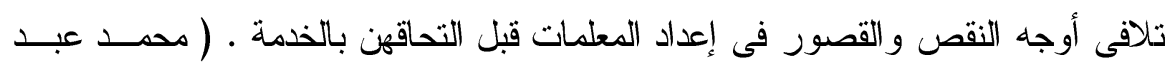

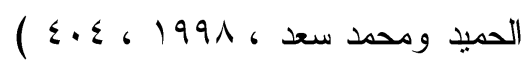




\section{المجلة العلمية لكلية رياض الاطفال - جامعة اسيوط}

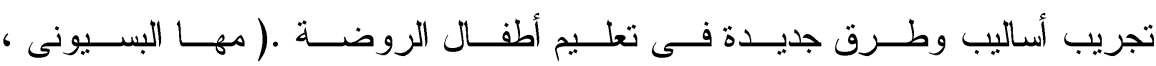

$$
\text { ( r ، r... }
$$

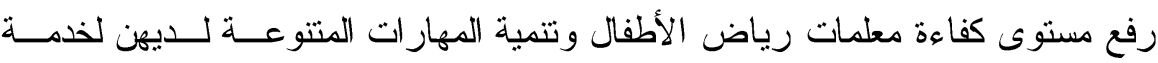

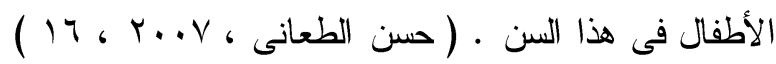

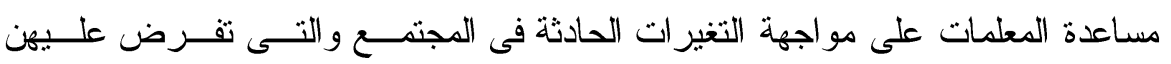

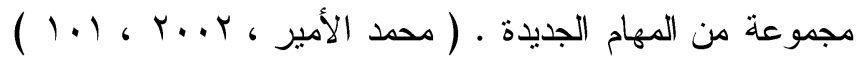

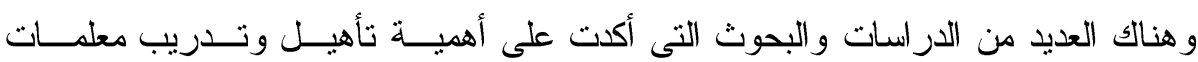

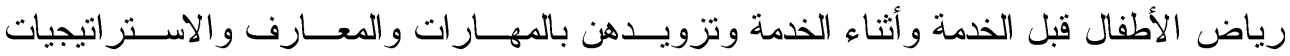

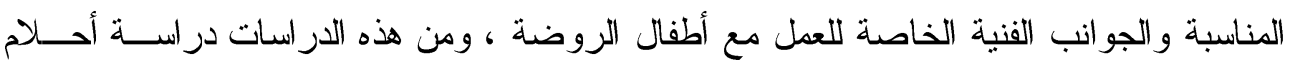

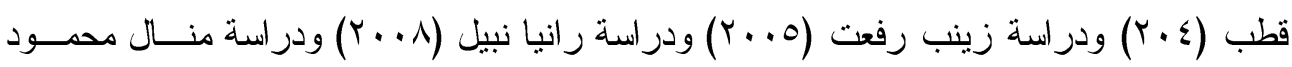

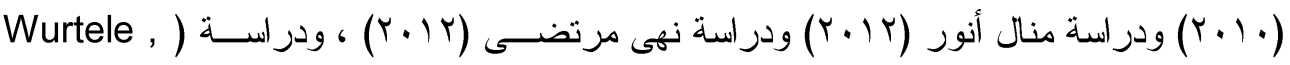

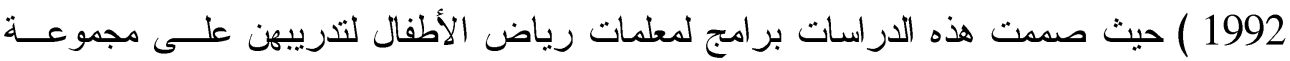

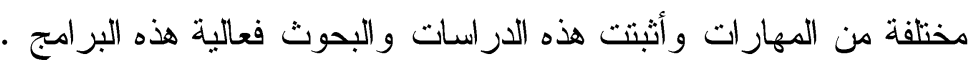

\section{ثنانياً: اضطر ابات النطق :}

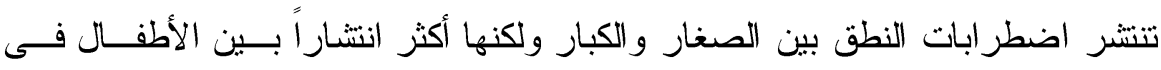

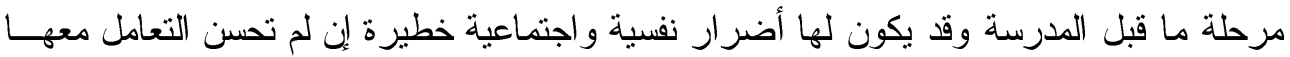

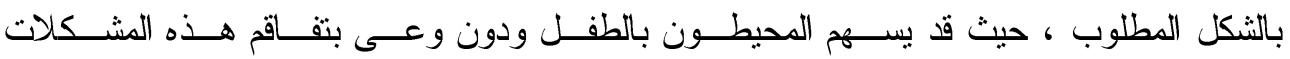
وتأخير حلها . بأنكل

\section{تعريف اضطر ابات النطق :}

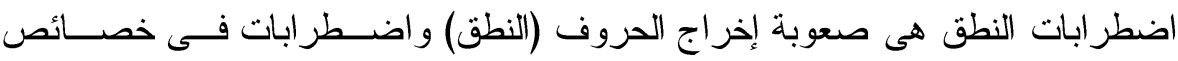

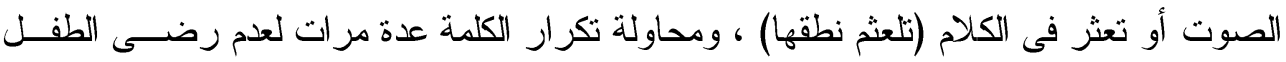
نفسه عنها ومو اجهة بعض الأطفال الذين يعانون من اضطر ابات في النطق لصعوبات فــى الفهـ

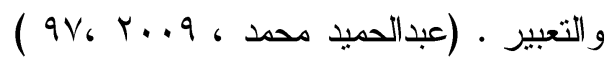

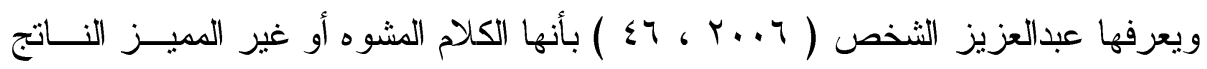

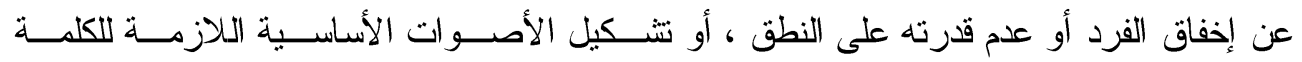


ويعرف ( Uwiere , et al ) اضطر ابات النطق بأنها مشــكلة أو صــعوبة فـى 2009

$$
\text { إصدار الأصوات اللازمة للكلام بطريقة صحيحة . }
$$

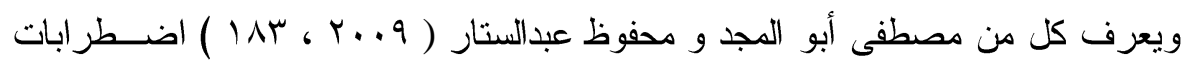

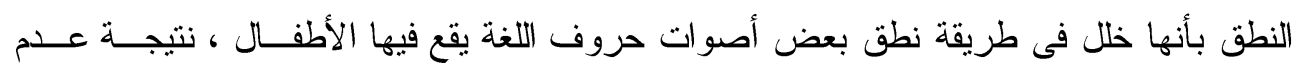

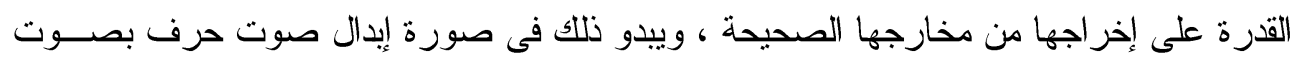

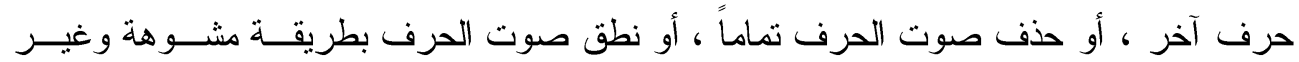

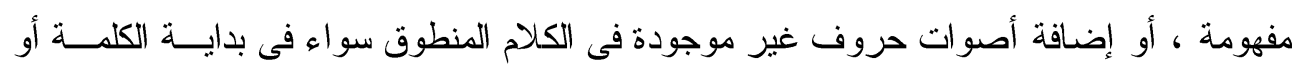

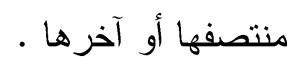

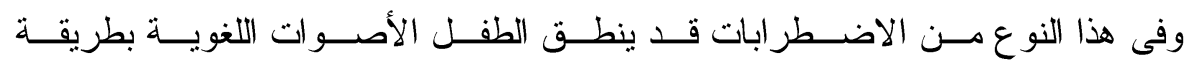

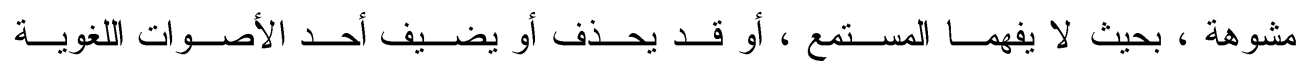

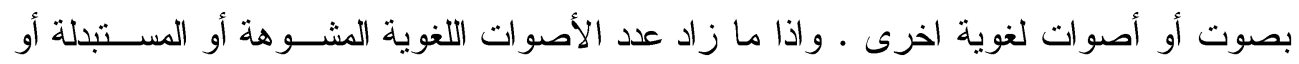

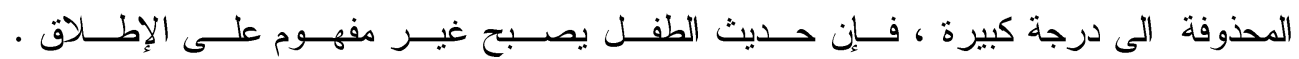

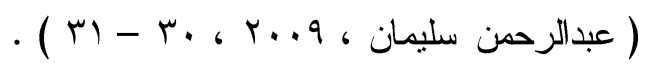

$$
\begin{aligned}
& \text { أسباب اضطر اباث النطق : }
\end{aligned}
$$

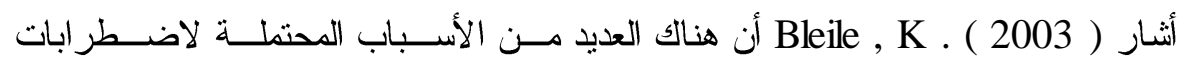

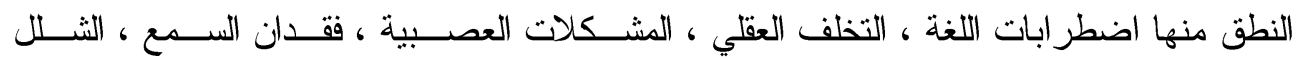

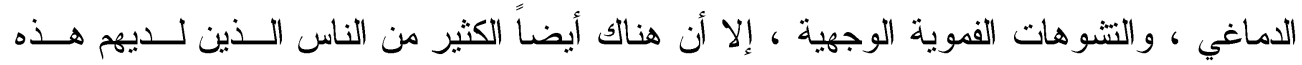

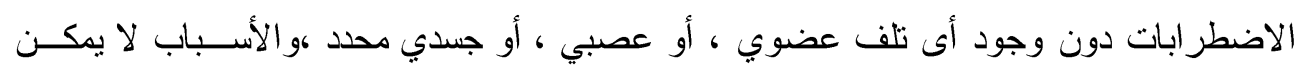
تحديدها ، في مثل هذه الحالات ، يمكن أن يسمى هذه الاضطراب " اضطر اب النطق الوظيفي " وترجع أسباب مشكلات و اضطرابات النطــق الــى مجموعــة مــن العوامـلـل النفســية و الاجتماعية و العضوية والانفعالية يمكن إجمالها فيما يلى :

أولاً : الأسباب العضوية :

قد ترجع عيوب الكلام إلى ضعف السمع ضعفاً يجعل الطفل عاجزاً عن التقاط الأصوات الصحيحة للألفاظ وقد يكون ضعف السمع خلقى أو مكتسب مع بداية ميلاد الطفل ويــرى uwiere , et al ( 2009 ) ، وكذلك ضعف السمع فى الأننين معاً أو فى أذن واحدة . 


\section{المجلة العلمية لكلية رياض الاطفال - جامعة اسيوط}

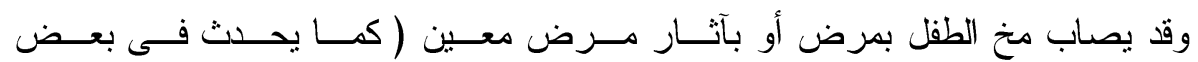

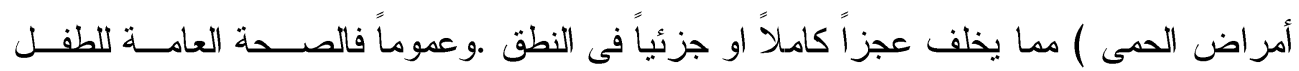

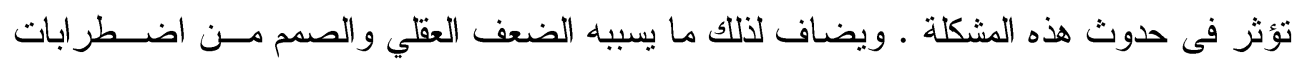

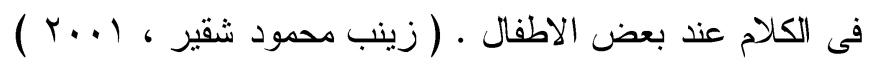

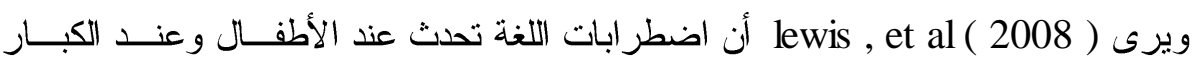

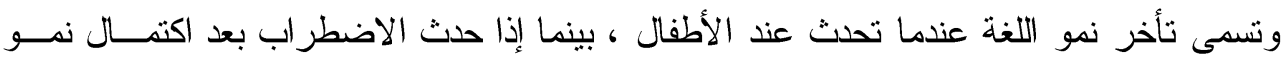

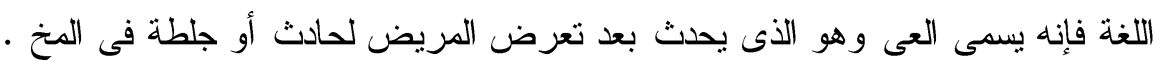

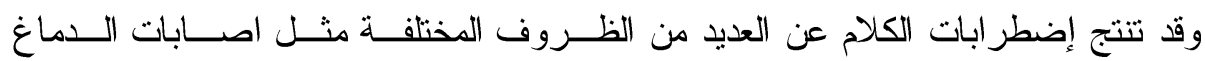

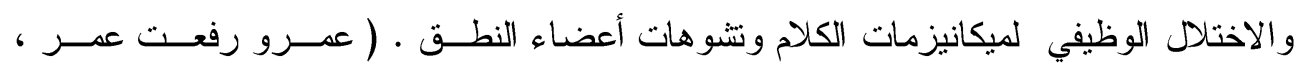
(1. . r. r.) ثانياً : الأسباب البيئية :

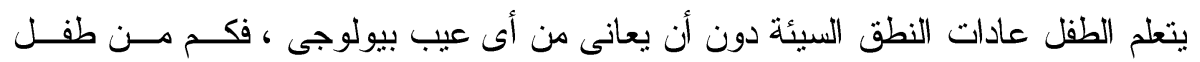

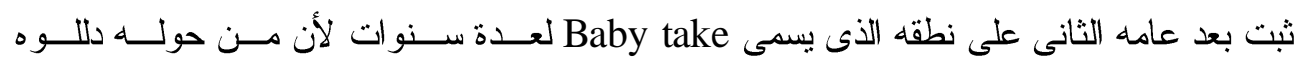

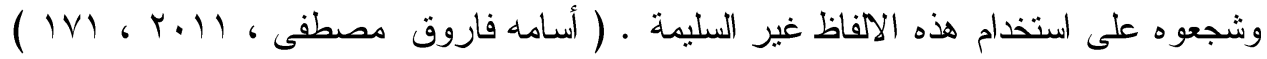

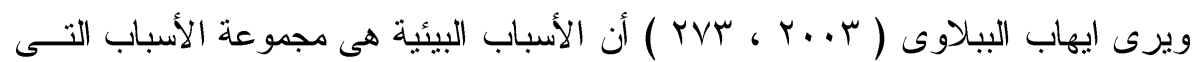

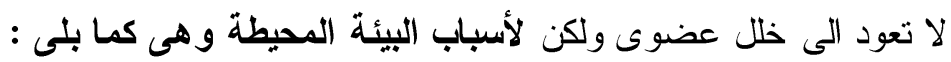

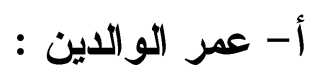
لعمر الوالدين دور حيوى فى اكتساب الطفل للغة وسلامة النطق .

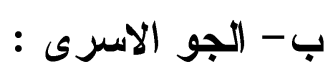

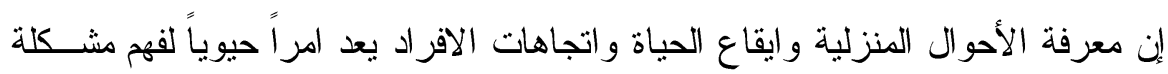

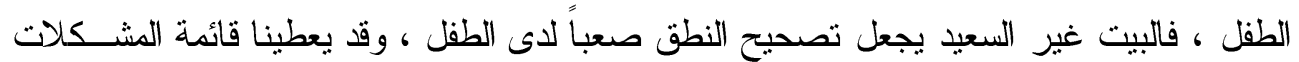

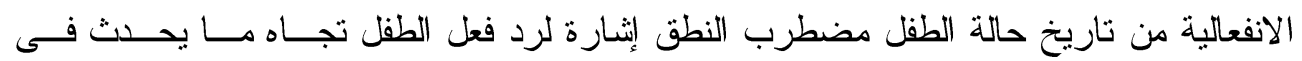

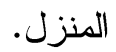

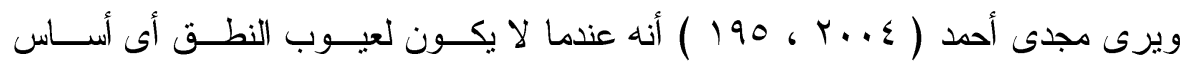

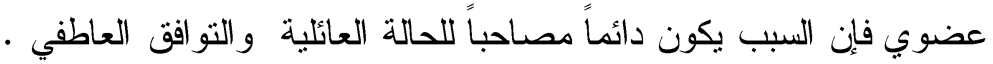


كما يرى إدو ارد كونتر ( 163 : 1982) Conture أن الظروف المحيطة بالطفل تكــون

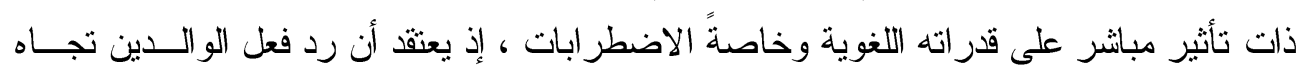

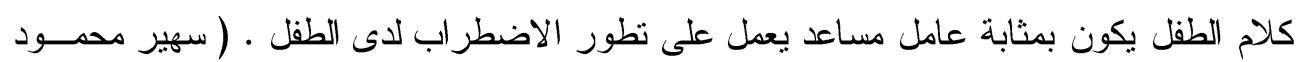

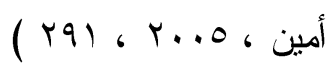

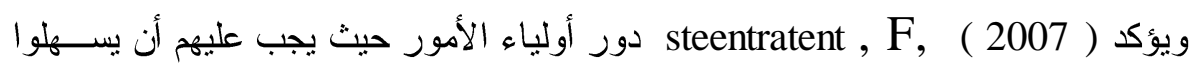

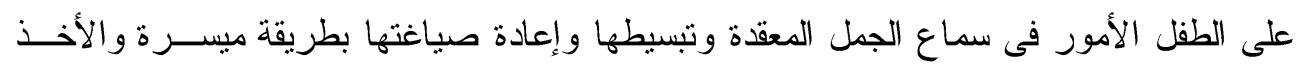
بلغة إيماءات الوجه وتبسيط المعلومة بكل الطرق. ج - التقليد والمحاكاه :

إن النقليد غالباً ما يكون أحد العوامل المسببة لاضطر ابات النطق ، فلو كانت الأم صماء

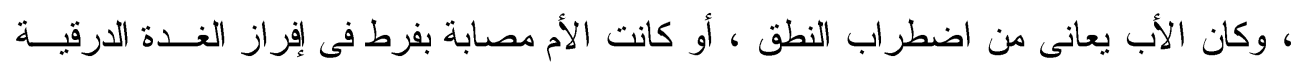

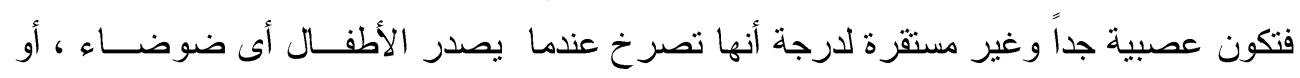

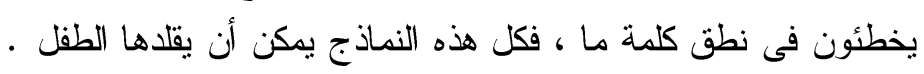

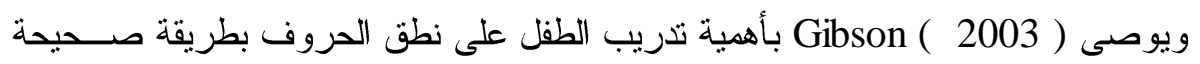
من خلال المحيطين به وتقديم نموذج جيد فى ذلك (

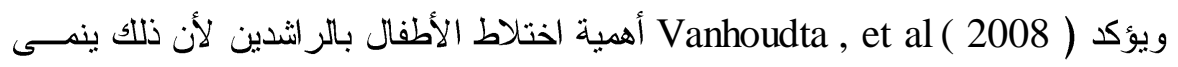

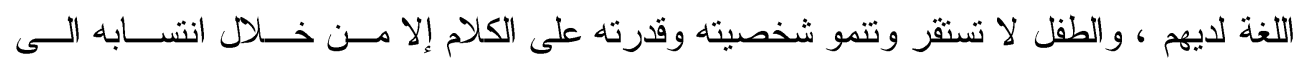

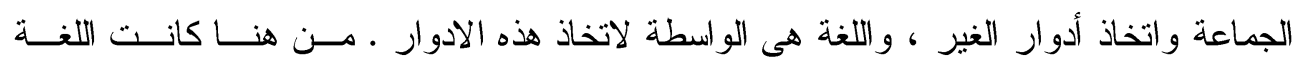

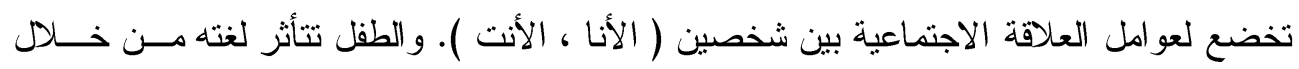

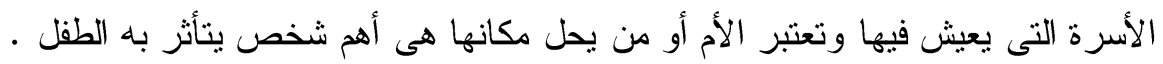

ثالثاً : الأسباب النفسية :

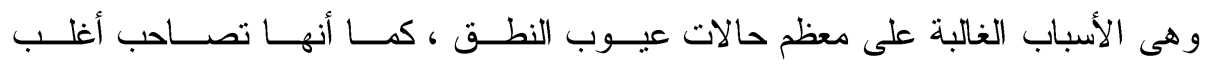

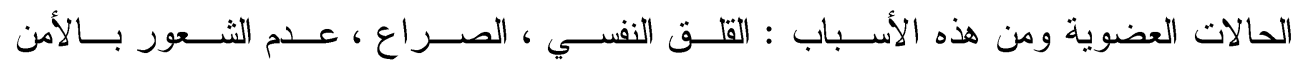

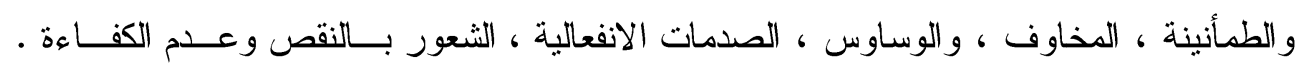

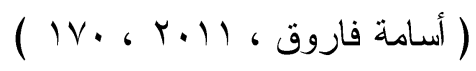




\section{المجلة العلمية لكلية رياض الاطفال - جامعة اسيوط}

ومن العوامل النفسية الثديدة التي تؤدى إلى اضطر اب الكــلام حـالات الخــوف والقــق

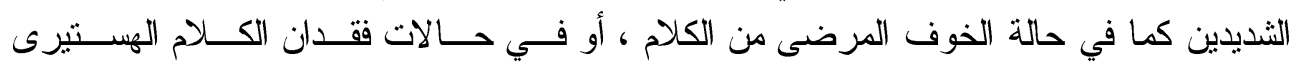

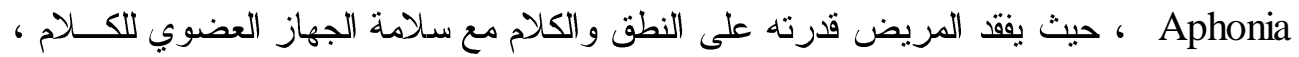

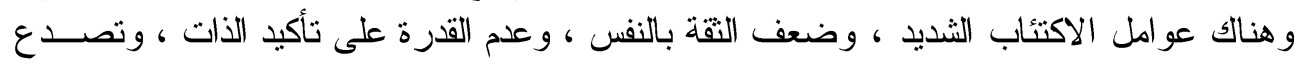

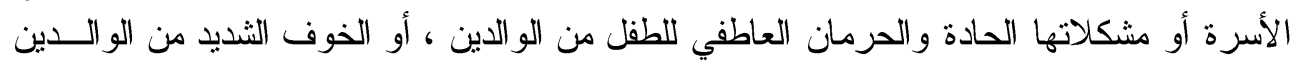

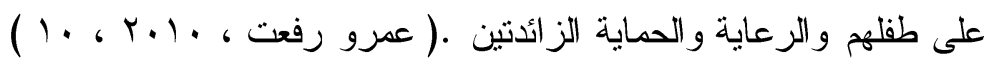

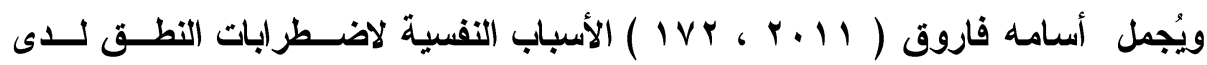

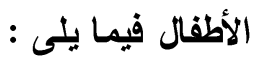
1- النزاع الأسرى بما يشمل من الخلافات بين الوالدين ، والطلاق ، والانفصال .

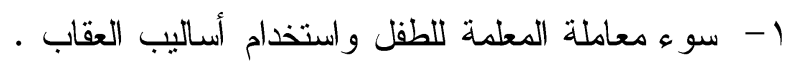

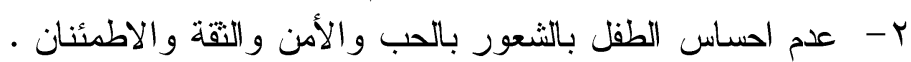

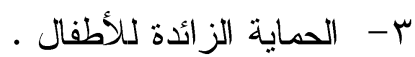

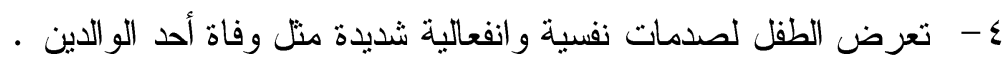

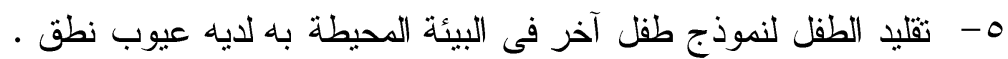

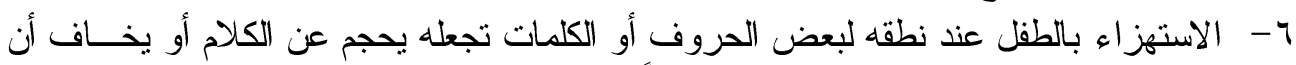

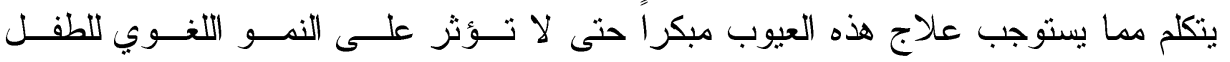

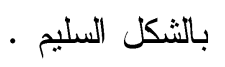

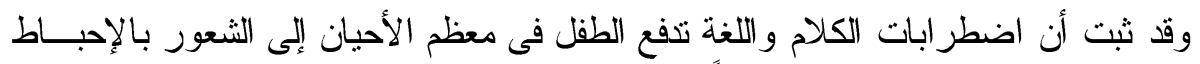

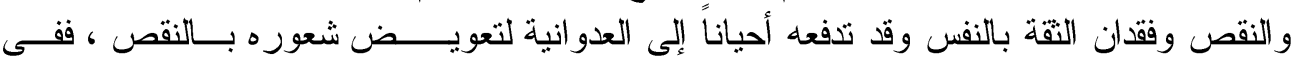

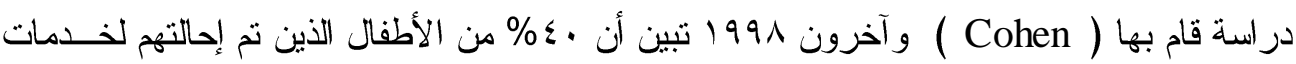

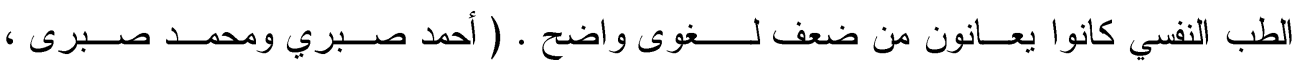
( $r \varepsilon$ ، r. 17

مظاهر اضطر ابات النطق : النق

- 1 الحذف :

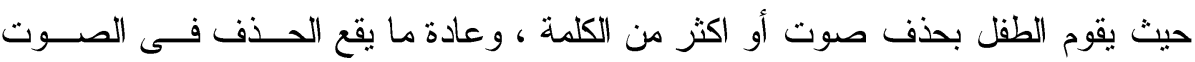

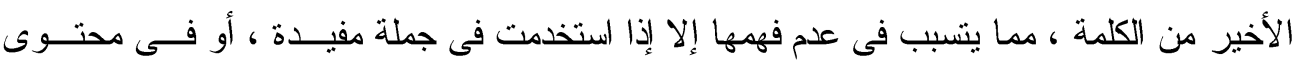

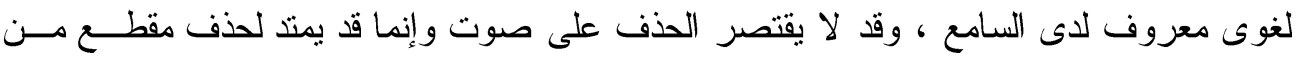

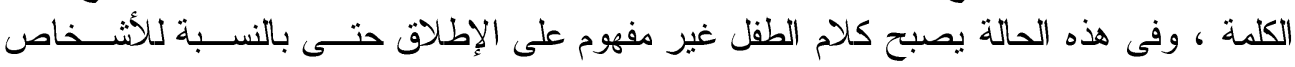

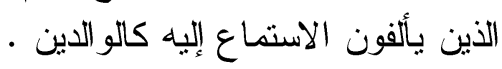




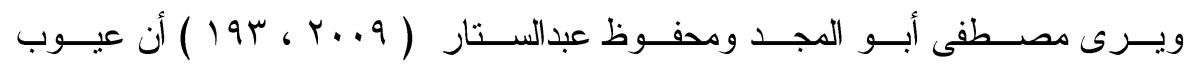

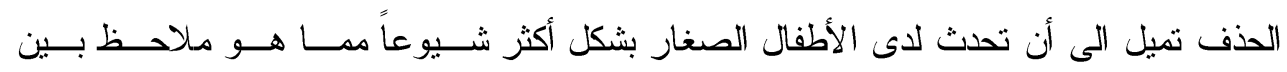
الأطفال الأكبر سناً ، كذلك تميل هذه العيوب إلى الظهور فى نطق الأصوات الساكنة فــى بدايــة

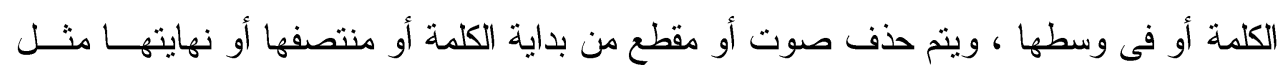

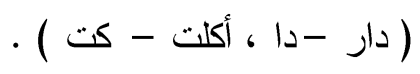

وتسبب عملية الحذف هذه صعوبة فى فهم كلام الطفل فى معرفة الحاجــة أو الفكـرة التــى يريد أن يعبر عنها مما يؤدى الى إرباكه وشعوره بعدم القدرة على إيصال أفكاره إلى الآخـرين مما يفقده الثعور بالتقة بالنفس.

$$
\begin{aligned}
& \text { ( IVA ، Y. II ، اسامه فاروق ) } \\
& \text { r - الإبدال }
\end{aligned}
$$

وهو عباره عن إبدال حرف / صوت بأخر عند الكلام ، وفى كثير من الحالات يكـون

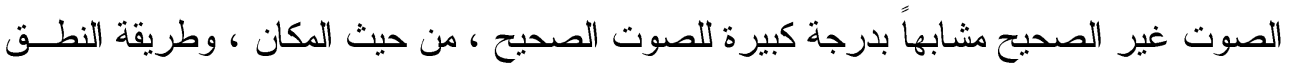
وخصائص الصوت ( مثال أحط بيها بدلاً من أحط فيهاً ، تلت سمت بدلاً من كلت سمك - الـــخ )

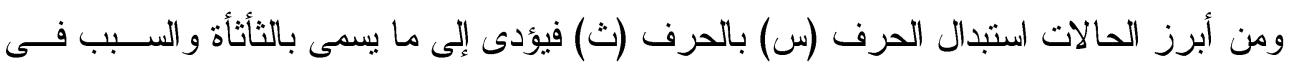
ذلك بروز طرف اللسان خارج الفم ، ومن الحالات الثائعة فى هذه الاضطر ابات أيضـاً اســتبدال

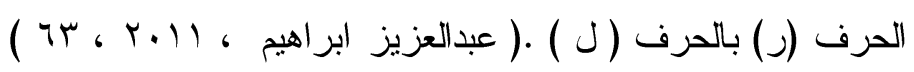
وقد يستبدل الطفل حرف ( س ) بحرف ( ش ) أو يستبدل حـرف ( ر ) بحـرف (و )

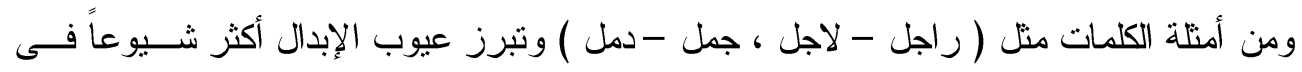

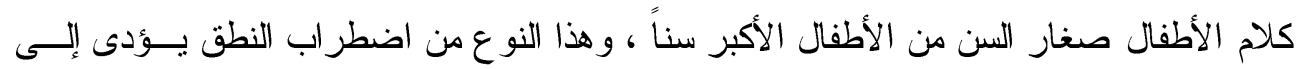

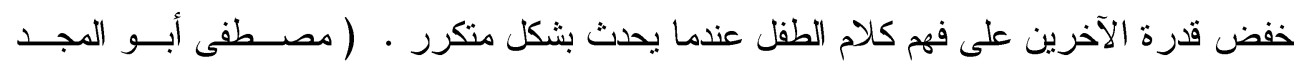

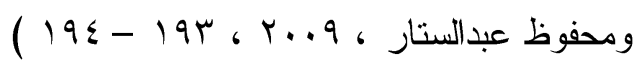

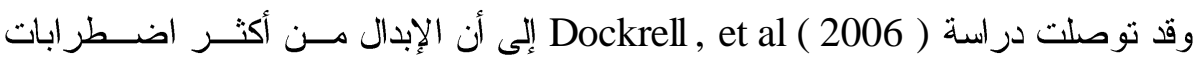
النطق انتشاراً بين الأطفال ويرجع ذلك إلى وجود نفس ذلك الاضطراب لدى الوالدين أو أحدهما. 


\section{r- التحريف أو التشويه :}

يتضمن التحريف نطق الصوت بطريقة تقربه من الصوت العادي بيد أنه لا يماتله تمامــاً

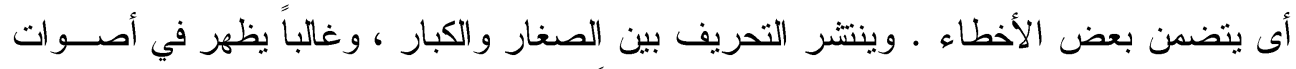

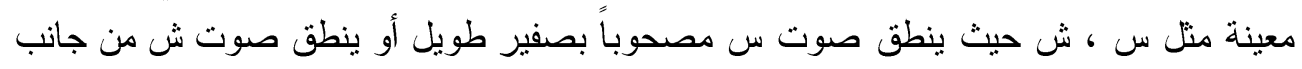

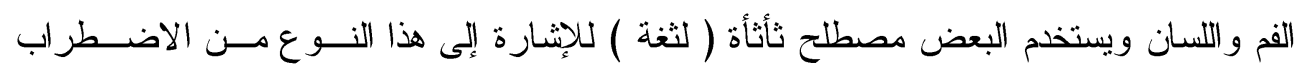

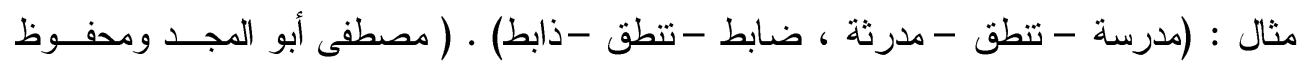

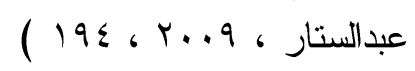

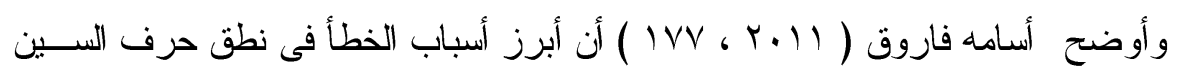

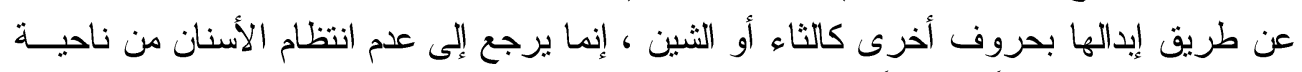

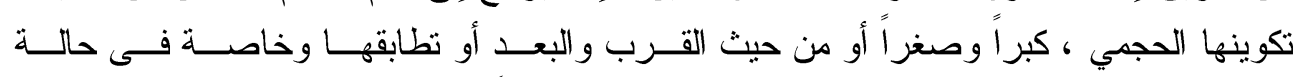

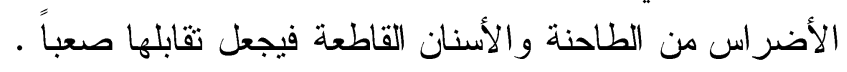

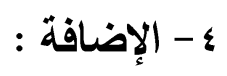

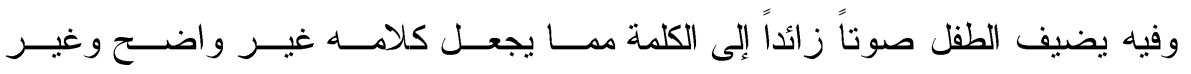

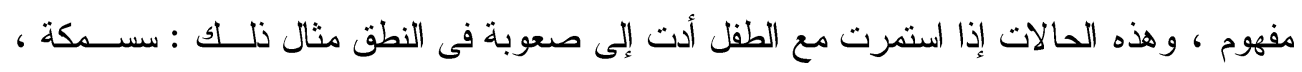

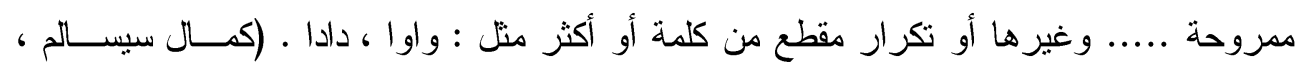
(ro. r.. r

\section{علاج اضطر ابات النطق :}

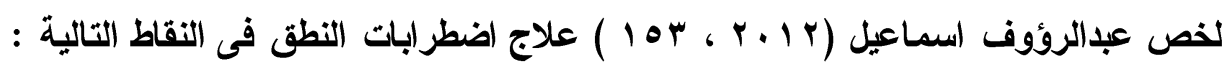

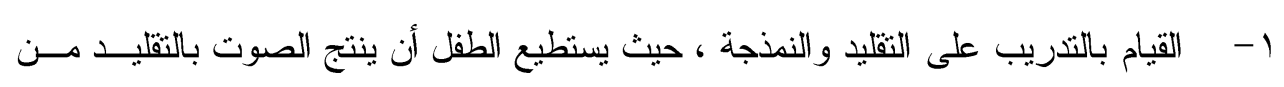

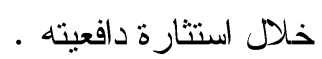

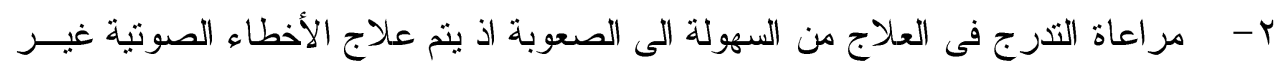

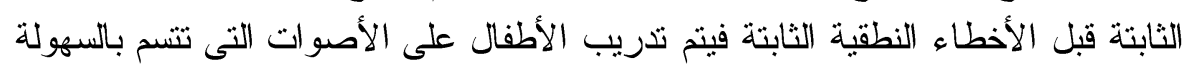

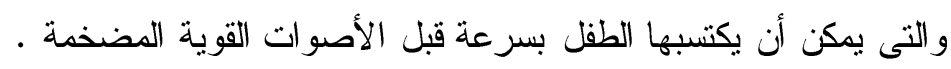

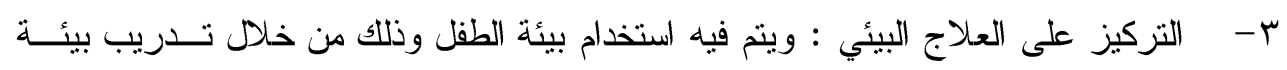

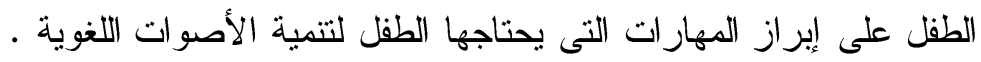

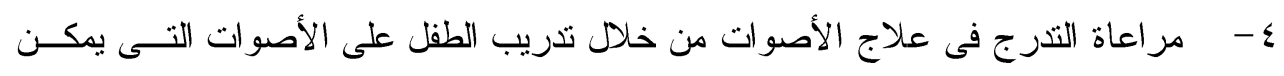

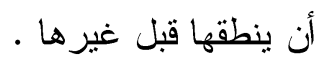
0- الأخذ بعين الاعتبار البدء بعلاج الأصوات التى تتكرر فى كلام الطفل قبل غيرها. 


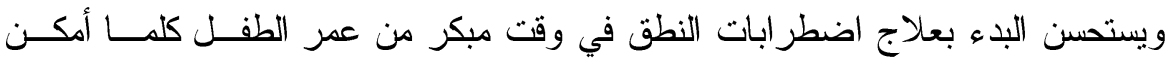

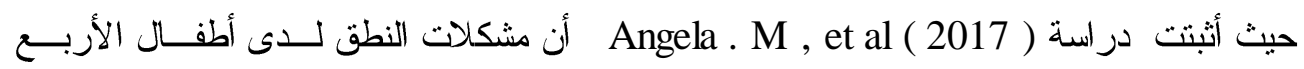

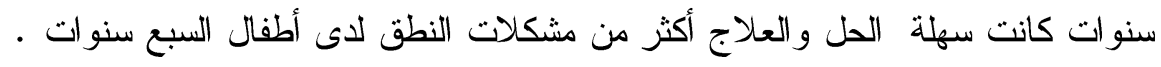

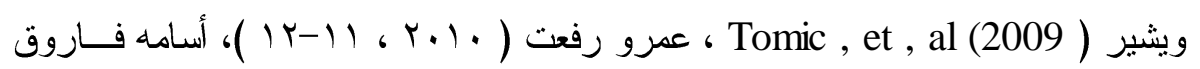

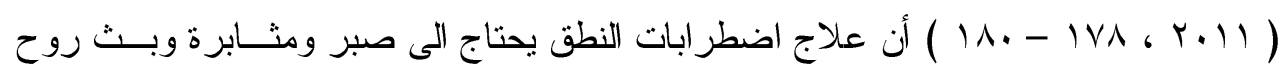

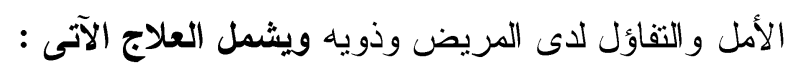

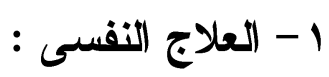

ولذلك لابد من تقليل الأثر الانفعالي والتوتر النفسي للطفـلـل ، كـــلك تتميــة شخصــيته

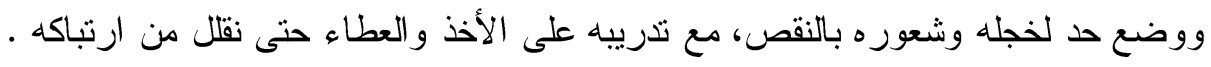

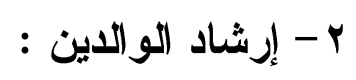

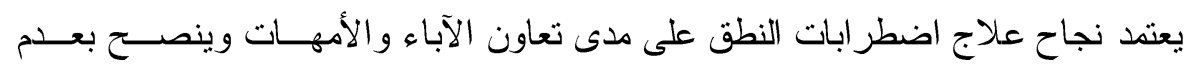

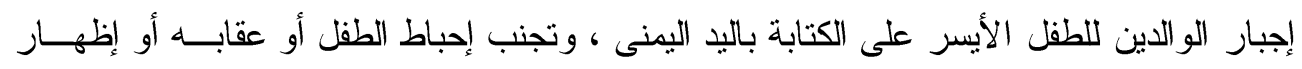

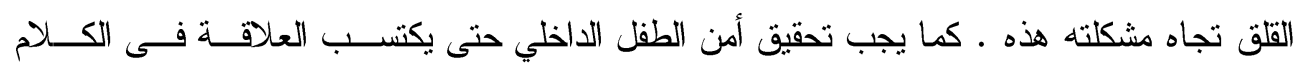

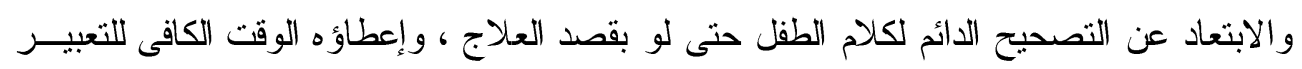
عن نفسه .

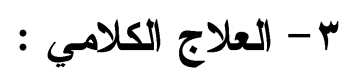

لتعليم الكلام من جديد والتدرج من الكلمات و المواقف السهلة إلى الصعبة وتدريب اللســان

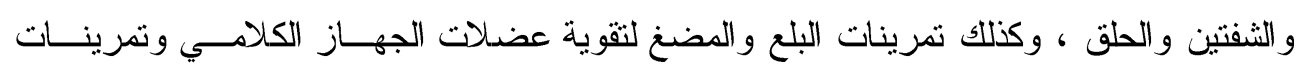

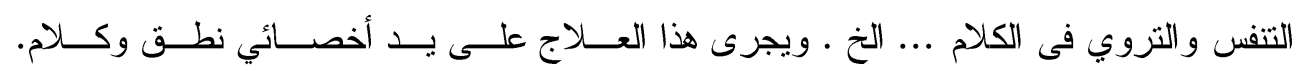

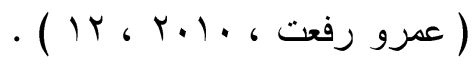

$$
\begin{aligned}
& \text { ع - العلاج الطبي : }
\end{aligned}
$$

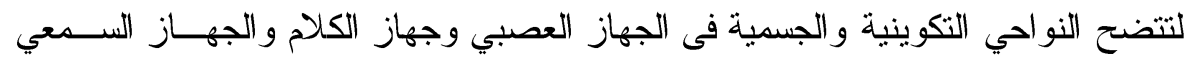

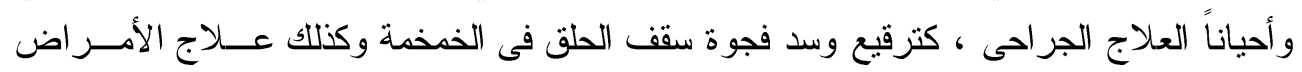

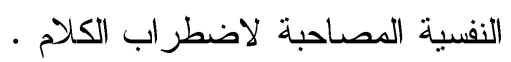




$$
\text { هـ العلاج البيئي : }
$$

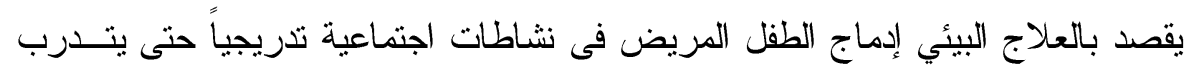

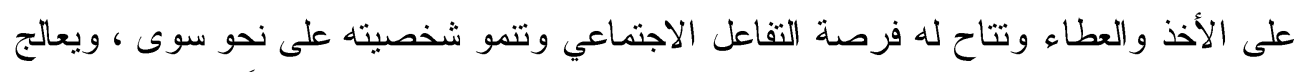

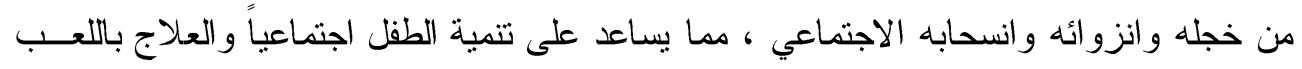

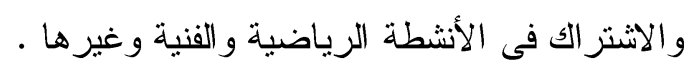

وسيتم فيما يلى عرض لمجموعة من الاراسات التى اهتمت بموضوع اضطر ابات النطق عند الأطفال: - دراسة مصطفى أبو المجد سليمان ومحفوظ عبدالستار أبو الفضل (9 . . . ب)

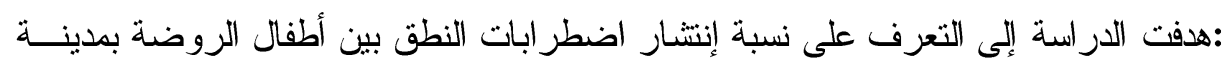

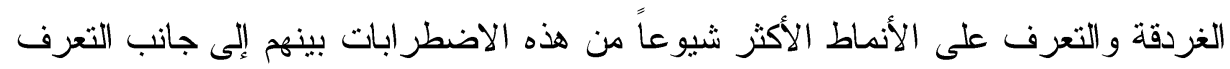

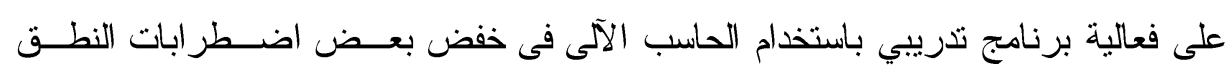

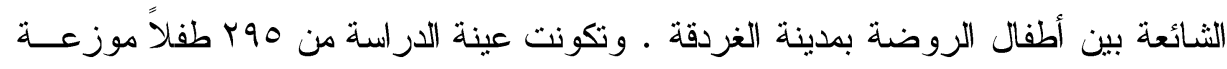

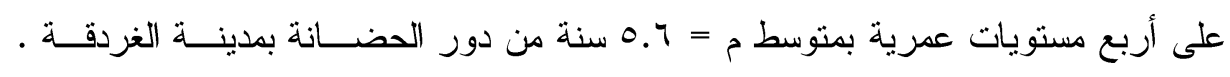

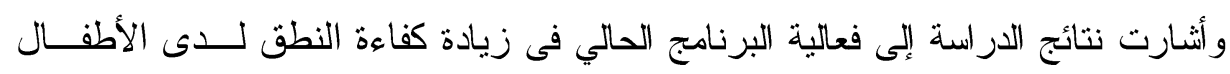
والحد من مظاهر إضطر ابات النطق لديهم.

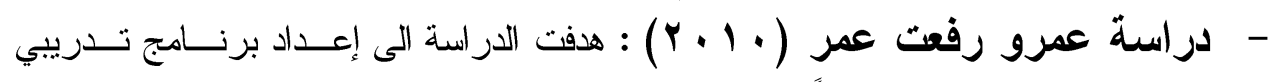

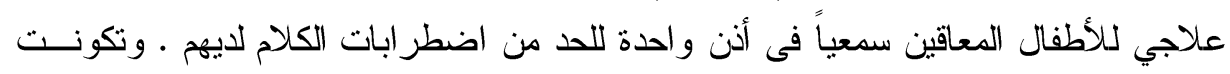

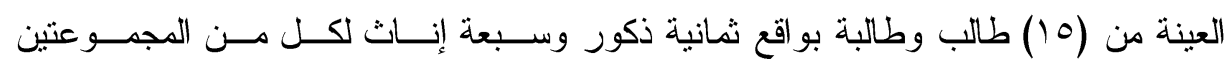

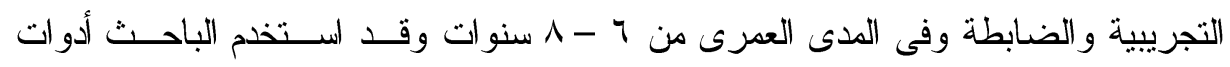

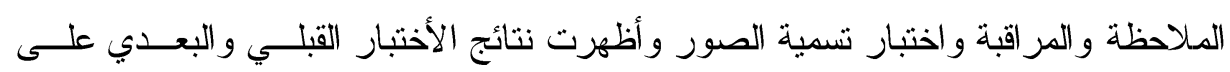

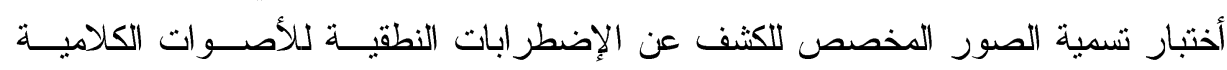

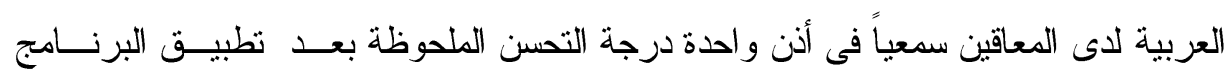

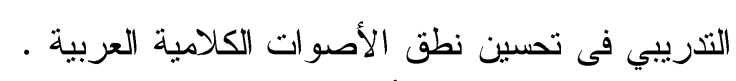

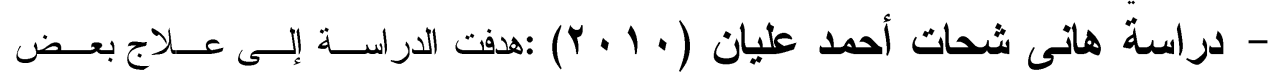

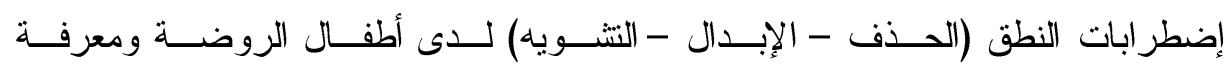

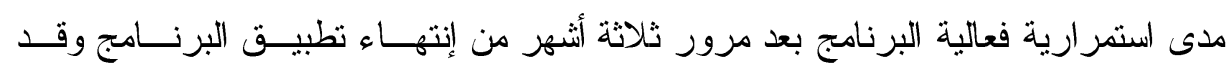

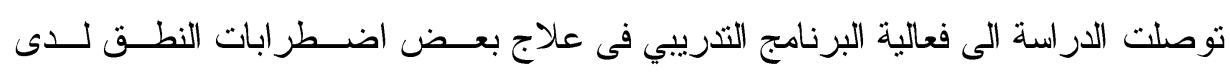
أطفال الروضة 


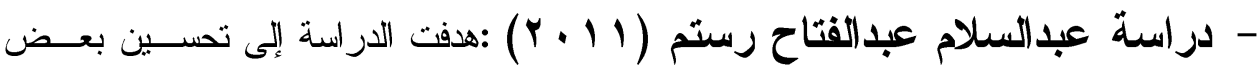

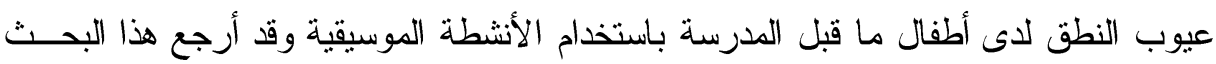

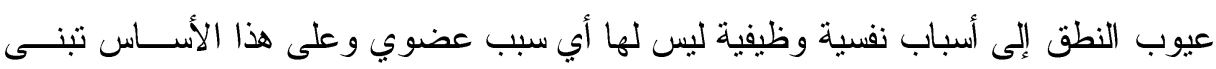

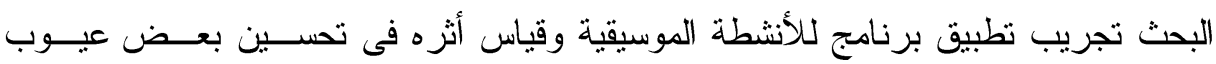

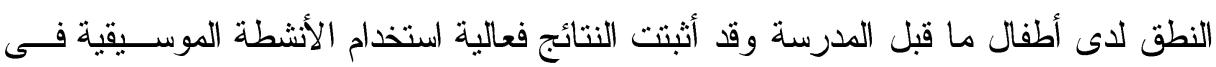

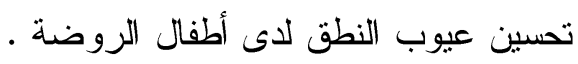

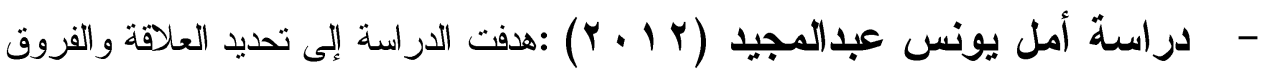

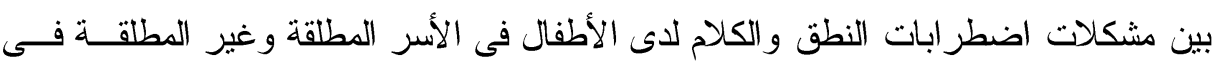

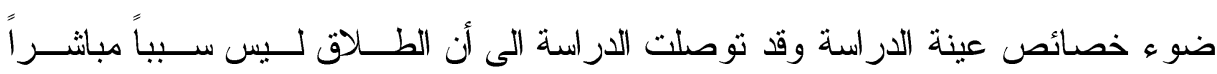

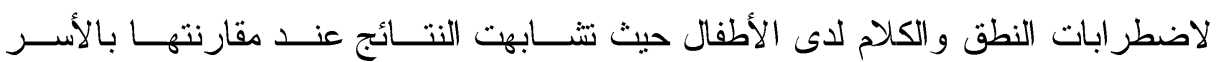
غير المطلقة .

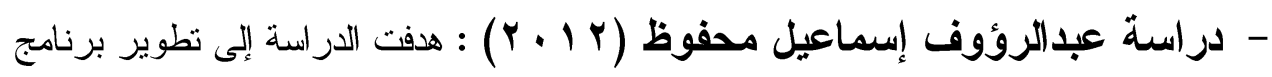

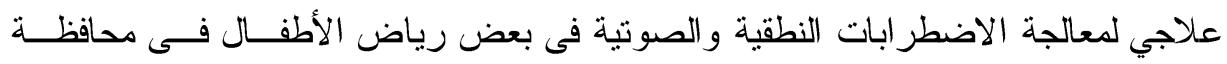

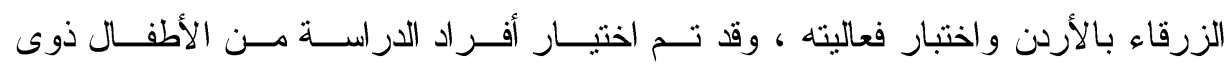

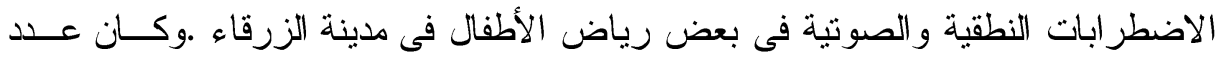

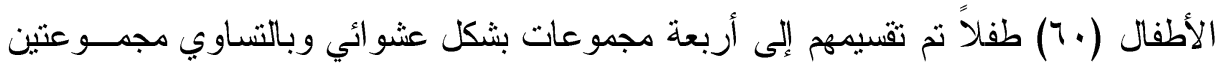

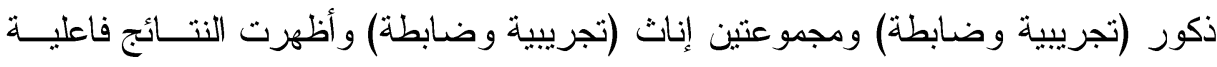

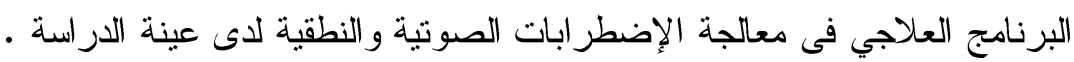

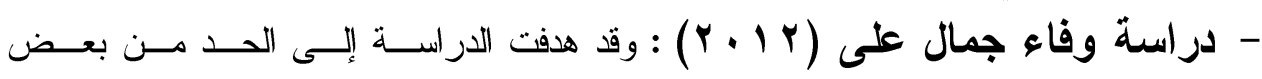

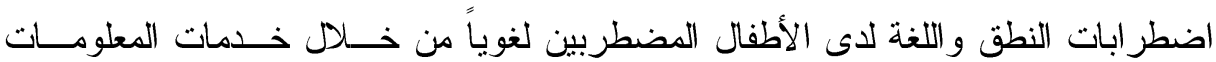

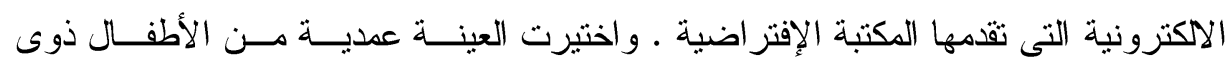
اضطرابات النطق و اللغة وقد اثبت البرنامج فعاليته .

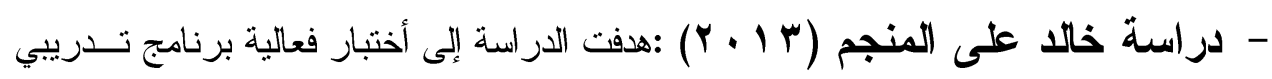

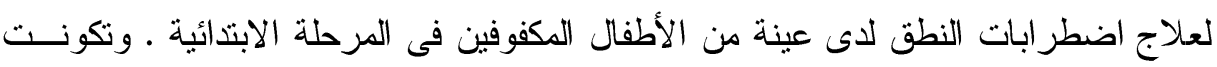

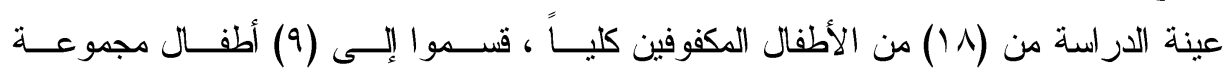

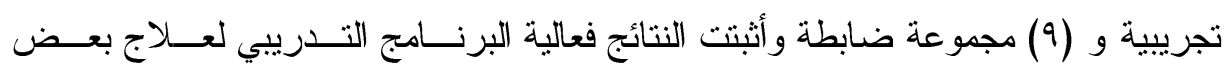
اضطر ابات النطق لدى الأطفال المكفوفين . 


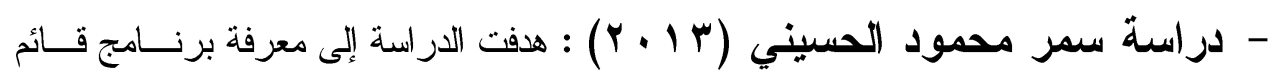

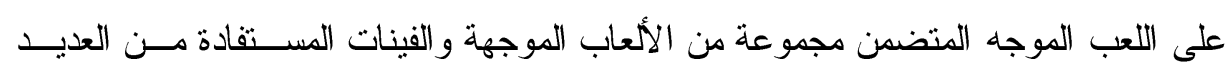

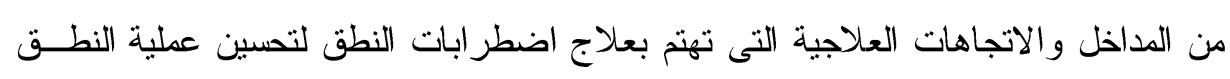

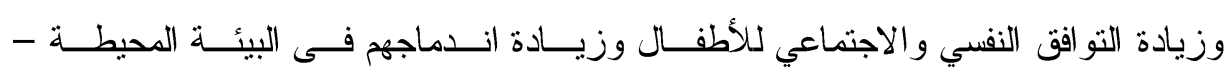

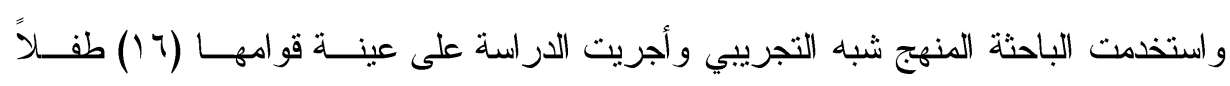

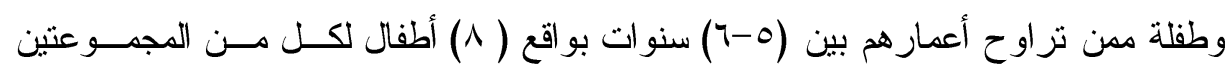
التجريبية والضابطة وقد توصلت الباحثة إلى وجــود فــروق ذات دلالــة إحصــائية بــين

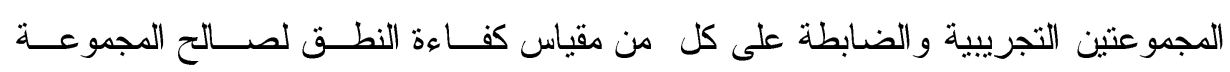

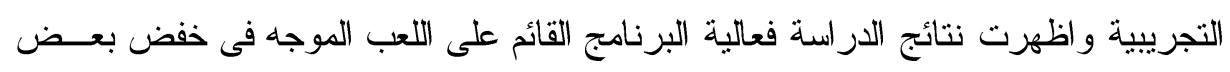
اضطر ابات النطق لدى الأطفال عينة الدراسة.

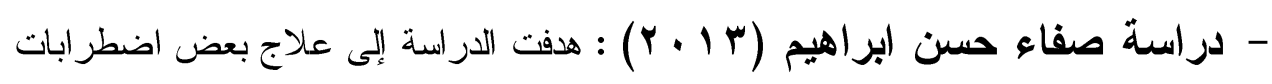

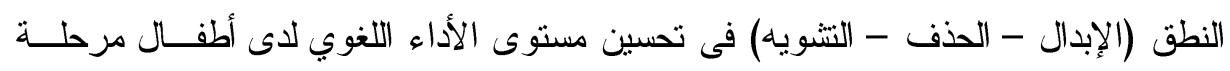

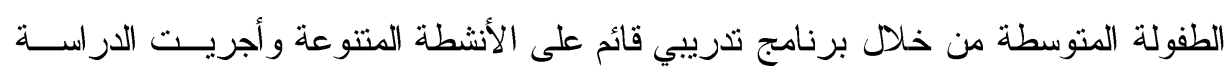

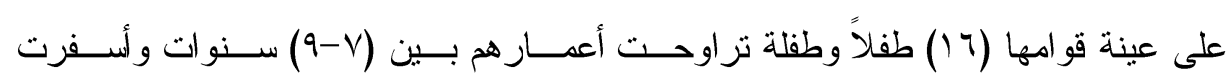

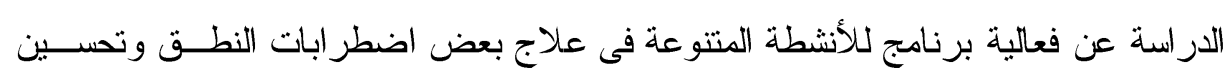

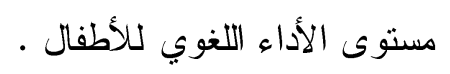

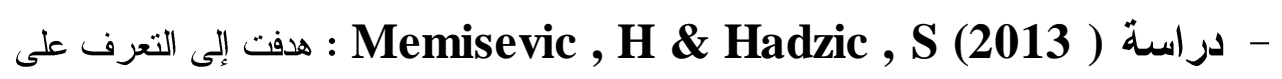

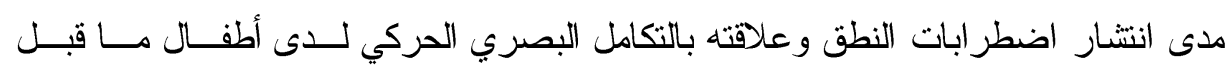

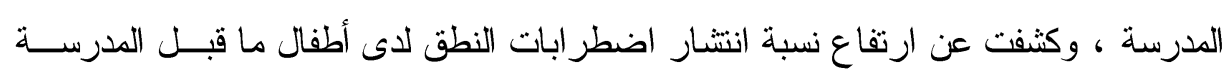

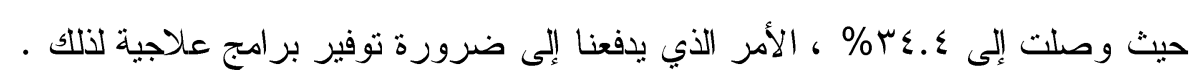




\section{التعقيب على الار اسات السابقة :}

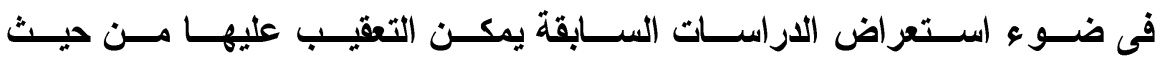
( الهاف ، والمنهج ، والعينة ، والأدوات ، والنتائج التى توصثت إليها الدراسات ) :

1- من حيث الهـف : تعددت الأهداف وتتوعت فى الدراسات السابقة ، حيث جاءت حسـب

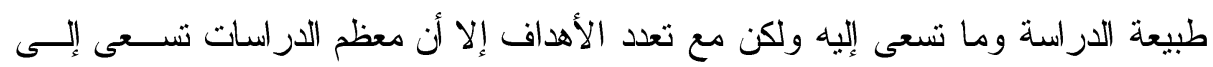

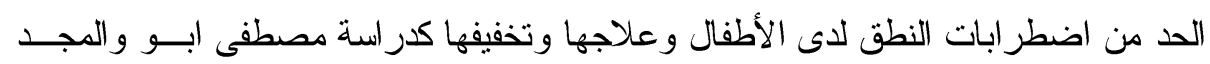

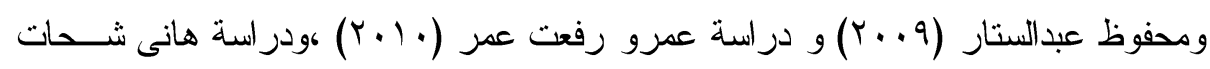

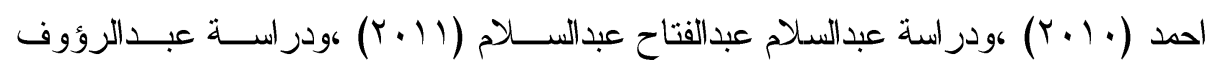

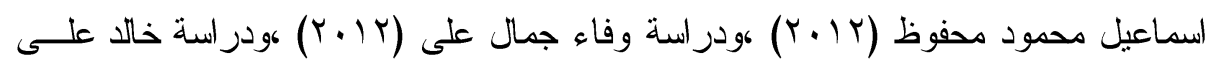

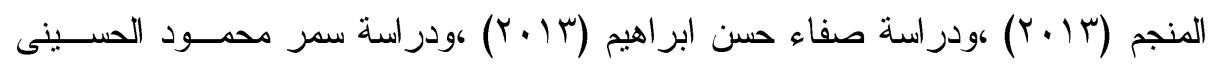

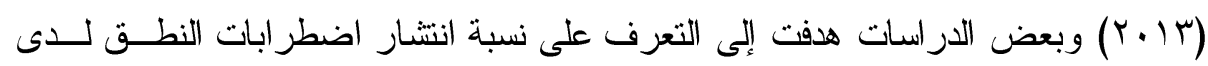

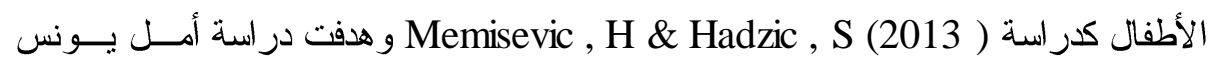

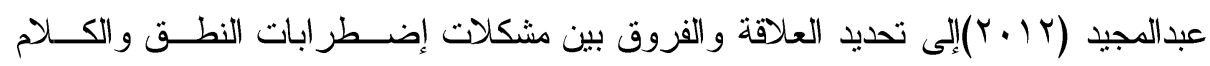
لاى الاطفال فى الأسر المطلقة وغير المطلقة.

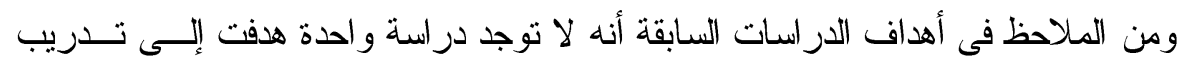

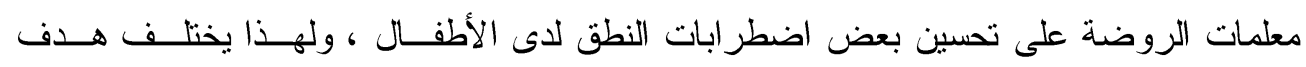
الدراسة الحالية مع الدراسات السابقة فى سعيها لتدريب معلمات رياض الحسن الأطفال.

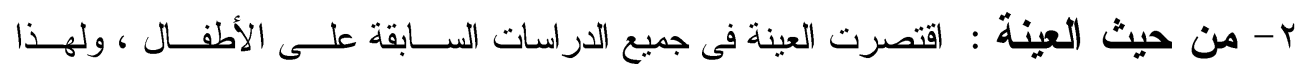
تختلف مع عينة الدراسة الحالية وهى مجموعة من معلمات رياض الأطفال .

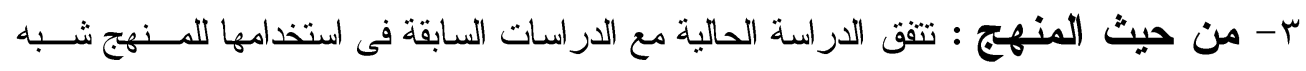

$$
\text { التجريبي من في }
$$

\section{أوجه الاستفادة من الار اسات (لسابقة :}

استفادت الباحثة من الدراسات السابقة فى صياغة مشكلة الدراســة وفروضـــها ، و إعـداد

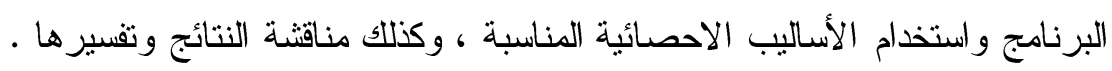




\section{فروض البحث :}

من خلا الإطار النظري والدراســات الســابقة ، فــإن البحــث الحسـالى يختبـر صـــة الفروض التالية :

1- توجد فروق ذات دلالة احصائية بين منوسطات درجات المعلمات ( عينة الدراســة ) فـى النطبيق القبلي لبطاقة الملاحظة ومتوسطات درجاتهن فى النطبيق البعدي لصــالح النطبيـق ترون

$$
\text { البعدي. }
$$

ץ- توجد فروق ذات دلالة احصائية بين متوسطات درجات المعلمات ( عينة الدراســة ) فــى النطبيق القبلي للاختبار المعرفي ومتوسطات درجاتهن فى النطبيق البعدي لصالح التطبيــق

$$
\text { البعدي. }
$$

r - توجد فاعلية للبرنامج المقترح فى تدريب المعلمات على تحسين بعض اضطر ابات النطــق

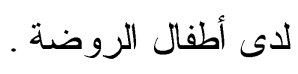

$$
\text { منهج البحث : البهن }
$$

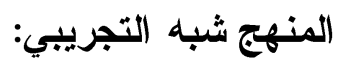

تم استخدام التصميم التجريبي القائم على المجموعة الواحـدة One Group ذات القيــاس

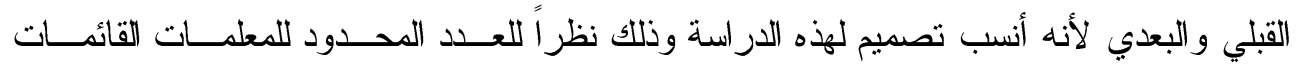

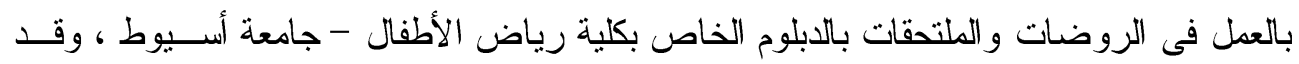

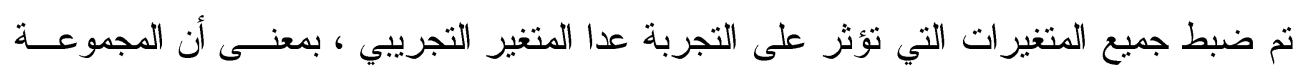

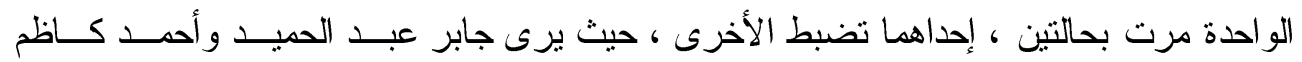

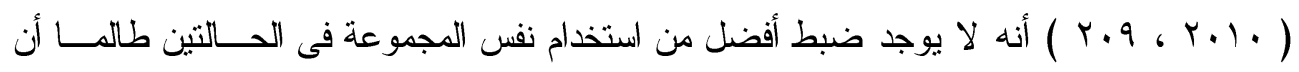

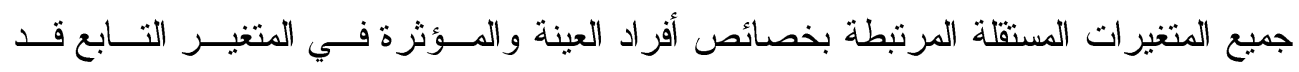

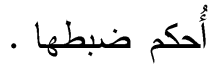




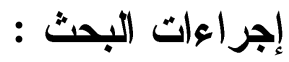 \\ أولاً : تصميم وإعداد مواد وأدوات البحث :}

ا - إعاد بطاقة الملاحظة لتقير المستوى الأدأي والمهاري لمعلمات الروضة فى تحسـين

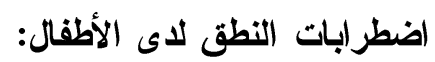

وفيما يلى عرض للخطوات التي اتبعت أثناء إعداد بطاقة الملاحظة لأداء المعلمات .

أ- الهدف من بطاقة الملاحظة .

ب- مصادر تصميم بطاقة الملاحظة .

جـ- محتويات بطاقة الملاحظة .

د- دعليمات بطاقة الملاحظة .

ه- النقدير الكمي لأداء المعلمات على بطاقة الملاحظة .

و - التجربة الاستطلاعية لبطاقة الملاحظة وحساب صدقها وثباتها.

وفيما يلى عرض تفصيلي لهذه الخطوات .

أ- الههف من إعداد بطاقة الملاحظة :

هدفت بطاقة الملاحظة إلى قياس أداء المعلمات مع الأطفــال ذوي إضــطر ابات النطــق

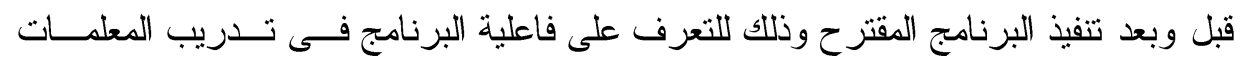
على تحسين بعض اضطر ابات النطق لدى أطفال الروضة .

ب - مصادر تصميم بطاقة الملاحظة :

تم الرجوع أثناء تصميم بطاقة الملاحظة إلى المصادر الآتية :

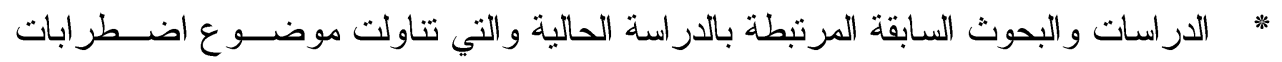

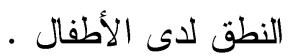

* الكتب و المر اجع المتخصصة فى اضطر ابات النطــق و المتخصصــة فــى مجــال تـدريب .

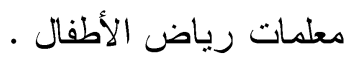




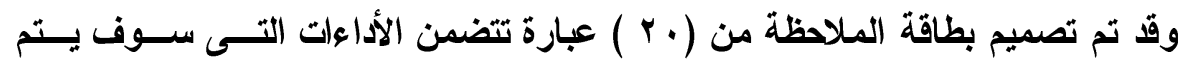

ملاحظتها.

\section{جـ- محتويات بطاقة الملاحظة :}

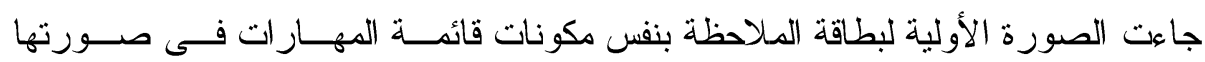

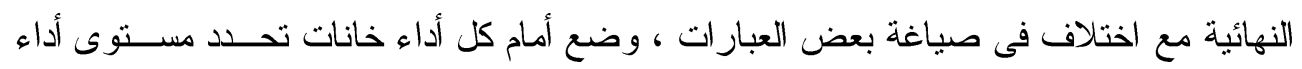

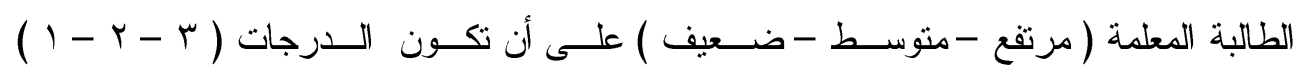

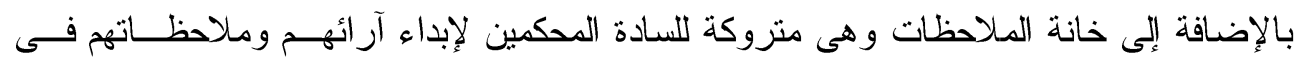

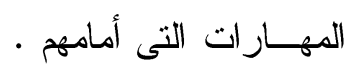

\section{د - تعليمات استخدام بطاقة الملاحظة :}

لإجر اء الملاحظة بصورة جيدة كان لابد من صياغة تعليمات و اضحة للملاحظين الـــين

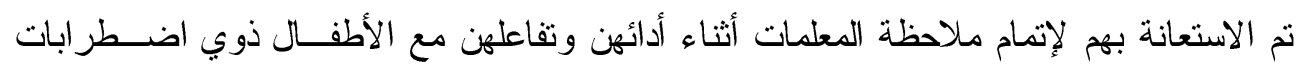

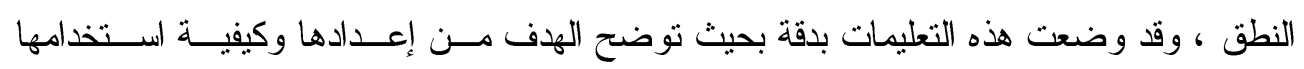
وكيفية وضع وتسجيل العلامات .

وتثتمل التعليمات التى وجهت لمن يقوم مع الباحثة بملاحظة المعلمة على ما يلى :-

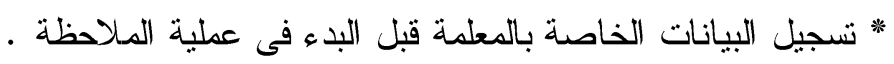

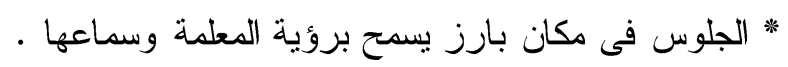

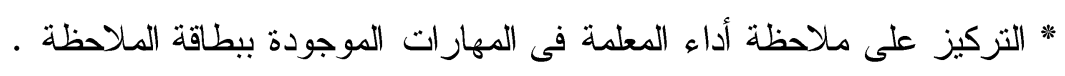

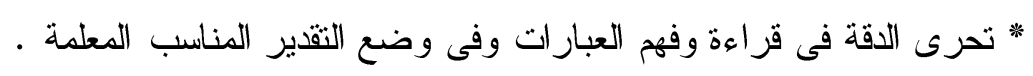

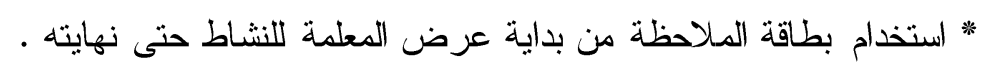

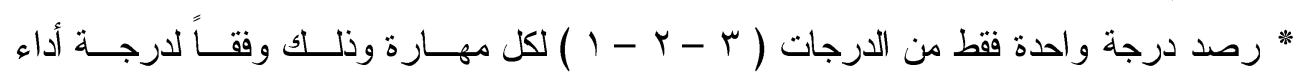

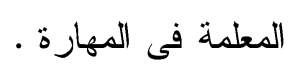

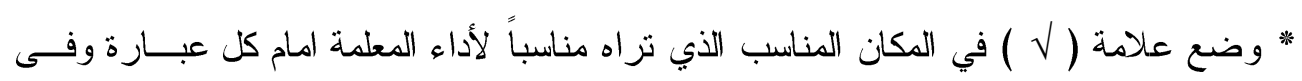

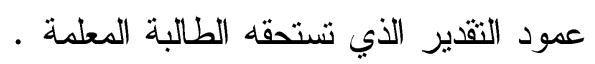

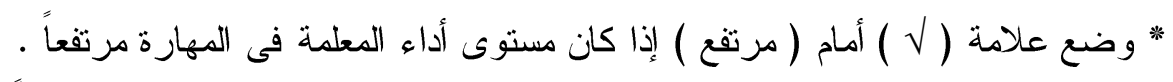
" "وضع علامة ( ل ) أمام ( متوسط ) إذا كان مستوى أداء المعلمة فى المهارة متوسطاً.

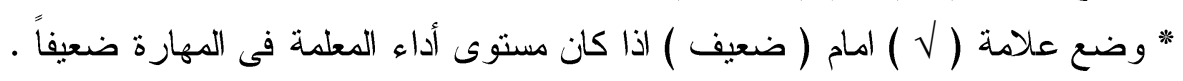

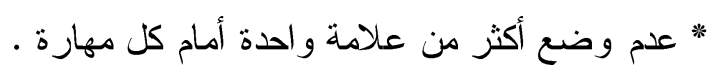




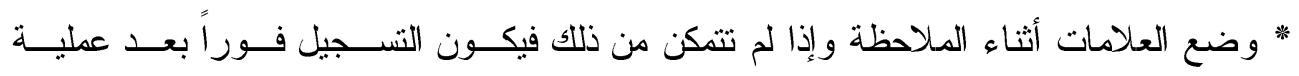

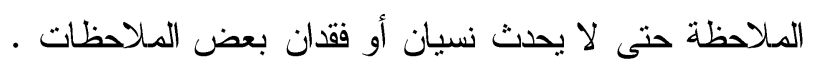

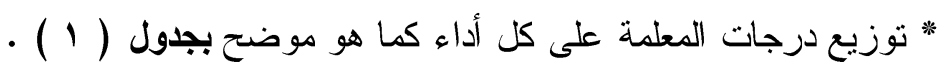

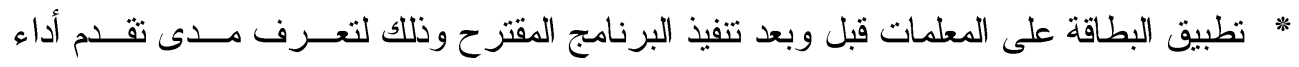

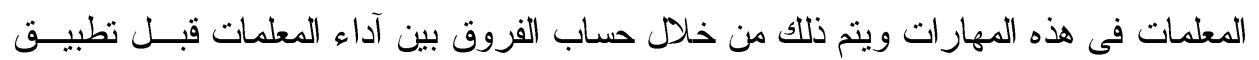

$$
\text { البرنامج وبعده - (البره }
$$

\section{ه- التقدير الكمي لأداء المعلمات فى بطاقة الملاحظة :}

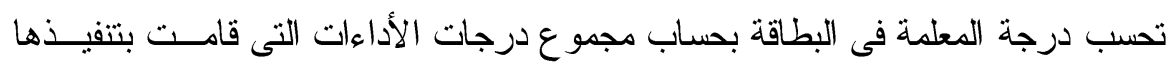

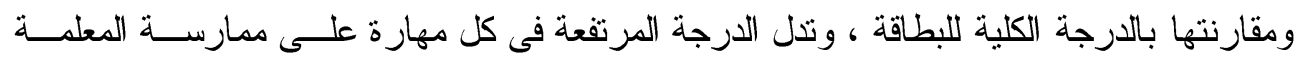

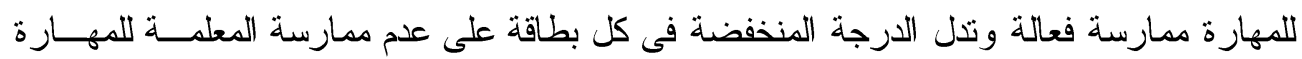

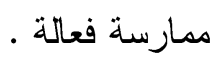

والجدول التالي يوضح توزيع الدرجات حسب مستويات أداء الطالبات المعلمات :

جدول (1)

توزيع الدرجات حسب مستويات أداء المعلمات على بطاقة الملاحظة

\begin{tabular}{|c|c|}
\hline الارجة & توزيع الارجات حسب المستويات \\
\hline ناتث درجات & قامت بالأداء بمستوى مرتفع \\
\hline درجتان & قامت بالآداء بمستوى منوسط \\
\hline درجة و احدة & قامت بالآداء بمستوى ضعيف \\
\hline
\end{tabular}

و - التجربة الاستطلاعية لبطاقة الملاحظة :

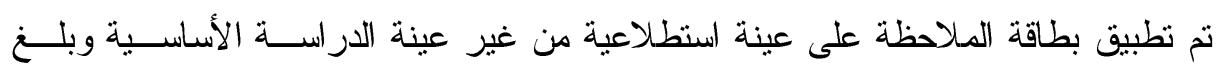

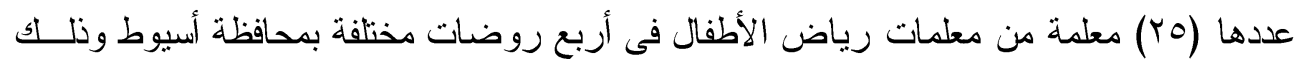
لحساب صدق وثبات بطاقة الملاحظة . - تم حساب صدق وثبات بطاقة الملاحظة كما يلى :

أولاً : صدق بطاقة الملاحظة :

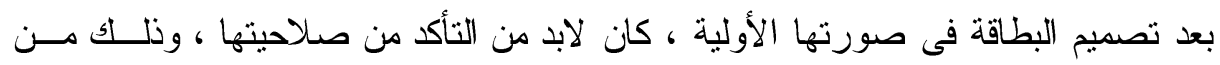
خلال حساب الصدق وقد استخدت الباحثة نوعين من الصدق . 


\section{Logical Validity الصدق المنطقي ( صدق المحكمين )}

لكى تتحقق الباحثة من صدق بطاقة الملاحظة قامت بعرضها على مجموعة من المحكمـين

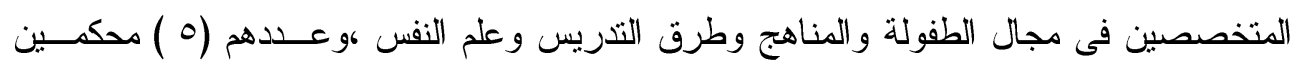

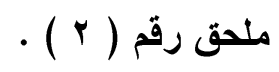

وقد أثنار السادة المحكمون أن المهارات الأدائية لهذه البطاقة تمنل تماماً ما وُضعت لقياسـهـ

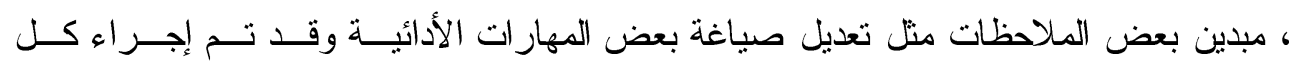

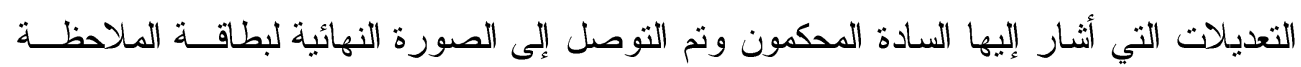

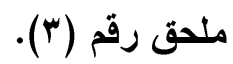

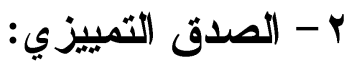
ويتم حساب الصدق التمييزي عن طريق حساب دلالة الفروق بـين الإربــاعي الأعلـى

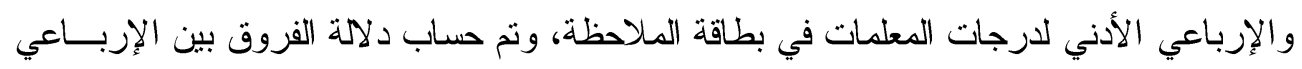

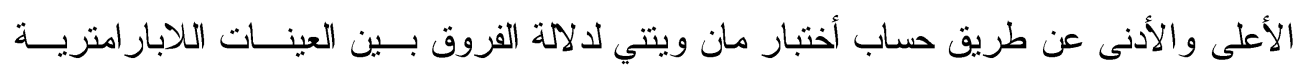
المستقلة، وجدول (r) يوضح ذلك.

جدول(r)

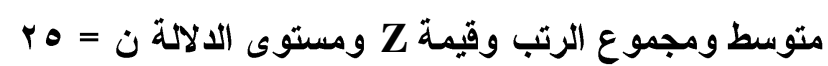

\begin{tabular}{|c|c|c|c|c|c|}
\hline الالالة & قيمة Z & مجموع الرتب & متوسط & العدد & المجموعة \\
\hline \multirow[t]{2}{*}{ دال عند ا... } & \multirow[t]{2}{*}{$\varepsilon .0 \mathrm{~V}$} & or & 7.0 & $\wedge$ & دنيا \\
\hline & & $1 \leqslant \varepsilon$ & 11 & $\wedge$ & عليا \\
\hline
\end{tabular}

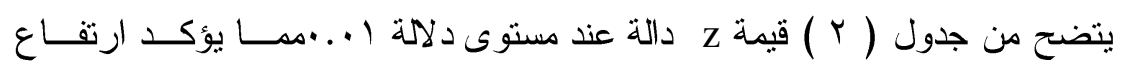

الصدق التمييزي للبطاقة . 


\section{ثانياً : ثبات بطاقة الملاحظة :}

تم حساب ثبات بطاقة الملاحظة بطريقتين هما :

\section{أ- طريقة ألفا كرونباك Alpha Cronbach Method}

تم حساب ثبات الاختبار عن طريق معادلة ألفا كرونباك ، وبلغت قيمة معامـل ثبــات

الكقياس ( اءي. . ) ) ، وهي قيمة مرتفعة تذل على ثبات المقياس.

$$
\text { ب - التجزئة النصفية لفقرات البطاقة : }
$$

وللتأكد من ثبات البطاقة تم تجزئة فقر اتها إلى أسئلة فردية وأخرى زوجيــة ثـــ حســاب

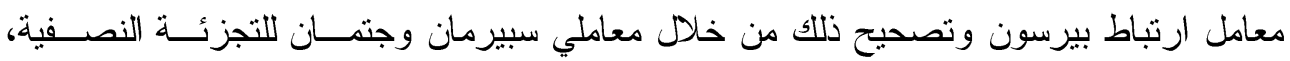

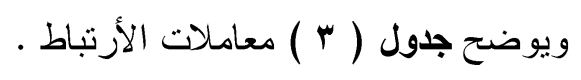

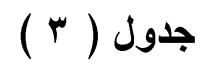

\begin{tabular}{|c|c|c|c|}
\hline اللالاة & معامل جتمان & معامل سبيرمان & الخو اص \\
\hline$\ldots 1$ & . . AYr & . . Ar. & البطاقة \\
\hline
\end{tabular}

معاملات التجزئة النصفية لبطاقة الملاحظة ن

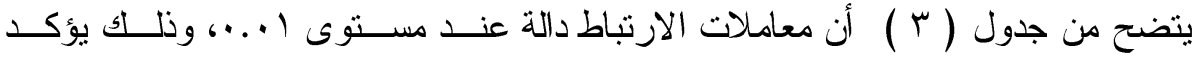

r - إعداد اختبار لقياس الجاتب المعرفى ل لاى معلمات الروضة في تحسين اضطرابات النطق : وفيما يلى عرض للخطوات التى اتُبت أثناء إعداد الاختبار المعرفي :

$$
\begin{aligned}
& \text { أ- الهذف من الاختبار . }
\end{aligned}
$$

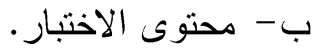

$$
\begin{aligned}
& \text { ج- تقدير درجات الاختبار وطريقة تصديحه . } \\
& \text { د- عرض الصورة الأولية للاختبار على المحكمين . } \\
& \text { م- الصورة النهائية اللاختبار • } \\
& \text { و - التجربة الاسنطلاعية الاختبار. }
\end{aligned}
$$

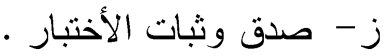

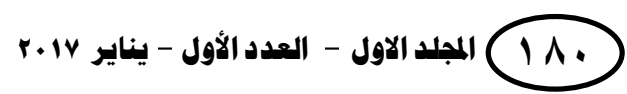




$$
\begin{aligned}
& \text { وسيتم فيما يلى شرح هذه الخطوات بالتفصيل : } \\
& \text { أ- الكهاف من الاختبار : }
\end{aligned}
$$

هدف الأختبار إلى قياس مدى اكتساب المعلمات للجانب المعرفــي لمحتـــوى البرنــامج

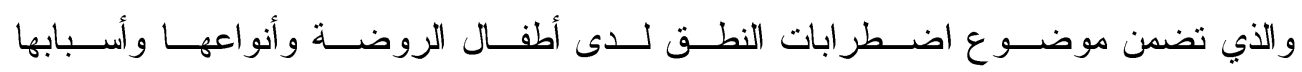
وطرق علاجها.

\section{ب- محتوى الاختبار :}

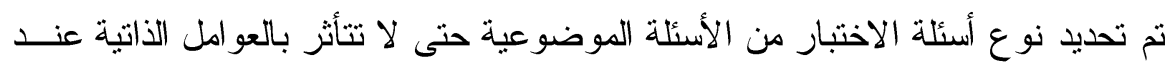

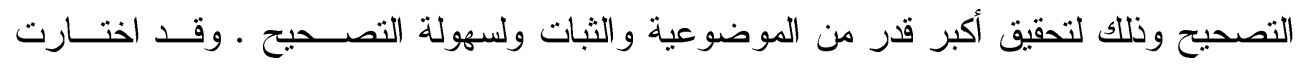

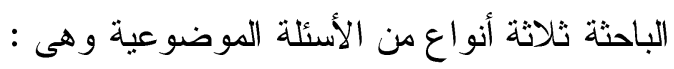

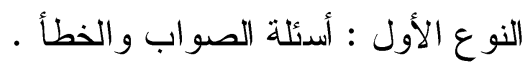

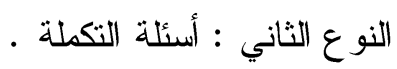

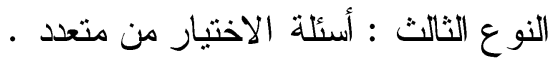
ج- تقدير درجات الاختبار وطريقة تصحيحه :

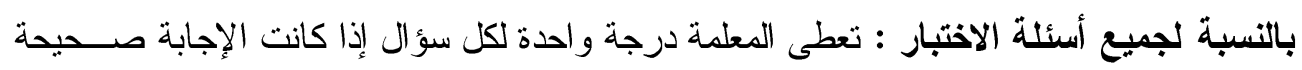

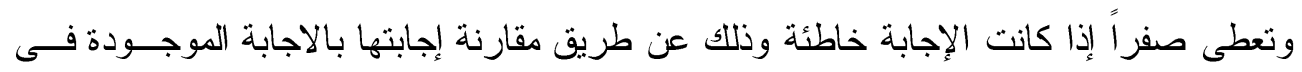

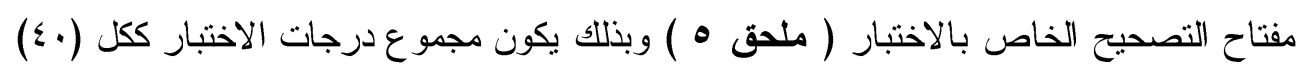

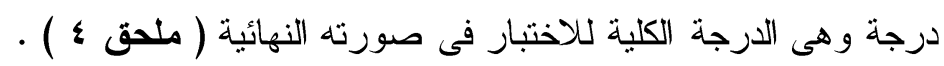
د - عرض الاختبار على المحكمين : بعد الانتهاء من الصورة المبدئية للاختبار نت عرضه

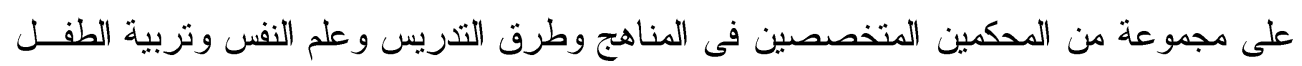

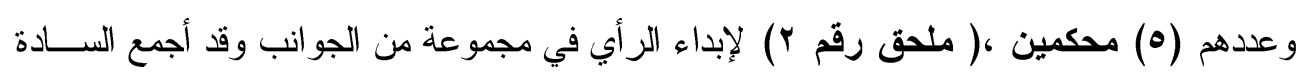

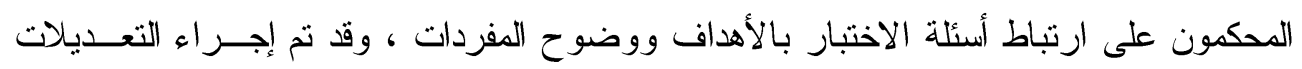

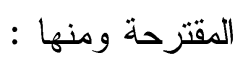

\section{أولاً : بالنسبة لأسئلة الصواب و والخطأ فقد تم الآتي :}

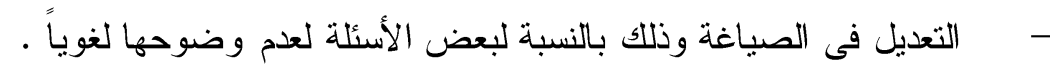

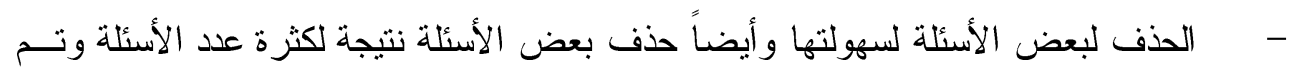

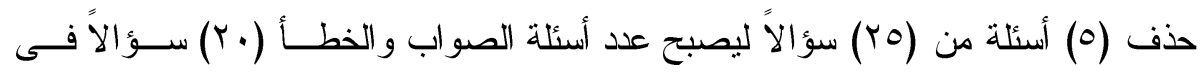

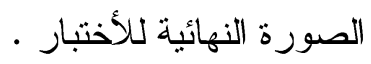


ثانياً : بالنسبة لأسئلة التكملة :

تم إعادة صياغة بعض الأسئلة وحذف بعضها ، ليصبح عدد الأســئلة (• () أســلئة فـى

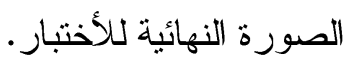

\section{ثالثاً : بالنسبة لأسئلة الاختيار من متعدد :}

تم تعديل صياغة بعض البدائل و أصبح عدد أسئلة الاختيار مـن متعـدـ (• (1) أســـلة فـى

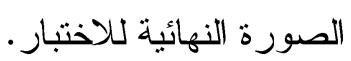
ه - الصورة النهائية للاختبار :

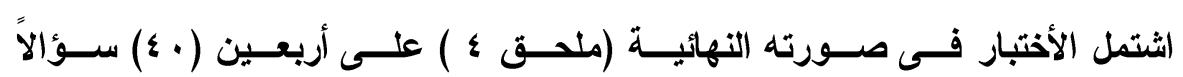

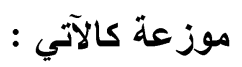

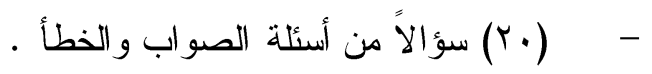

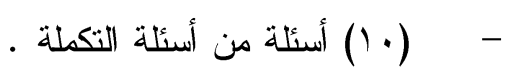

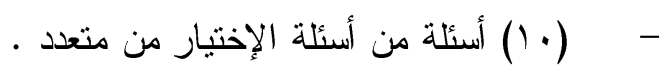
و - التجربة الاستطلاعية للاختبار :

بعد تصميم الأختبار فى صورته النهائية ، تم تطبيقه على عينة استطلاعية من غير العينــة

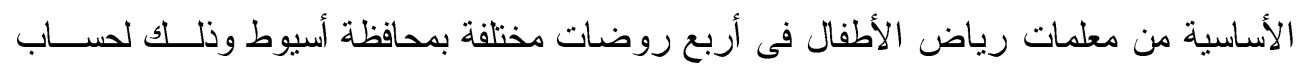
صدق وثبات الأختبار.

وقا هدفت التجربة الاستطلاعية إلى حساب كل من :

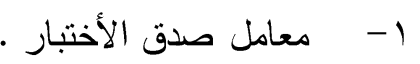

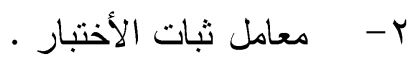

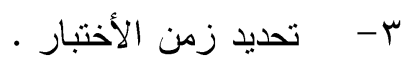

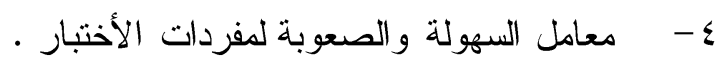




\section{أولاًا : صدق الأختبار : م}

اعتمدت الباحثة في حساب صدق الأختبار على ما يلي :

أ- - الصدق المنطقي ( صدق المحكمين ) Logical Validity

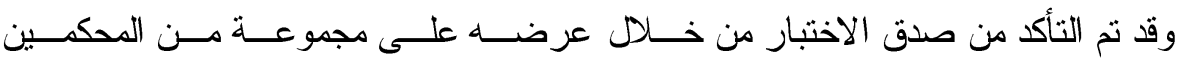

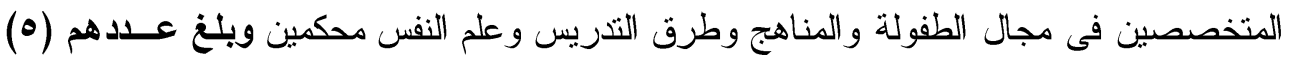

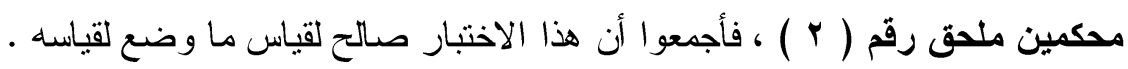

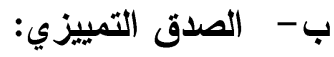

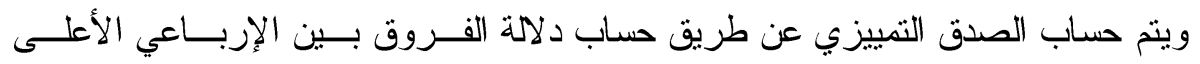

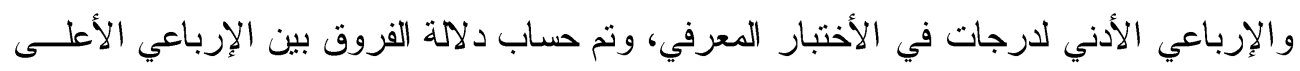

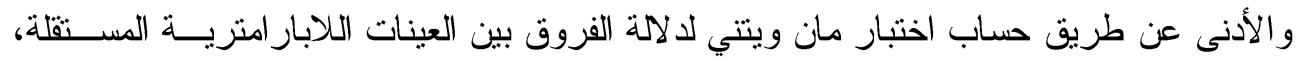
وجدول ( ع ) يوضح ذللك.

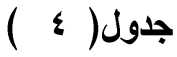

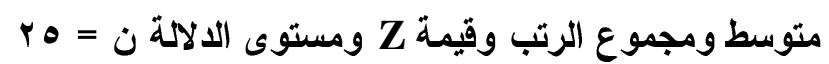

\begin{tabular}{|c|c|c|c|c|c|}
\hline الالامة & قيمة & ملجموع الرثب & متوسط الرتب & العلد & المجموعة \\
\hline \multirow{2}{*}{ دال عند ا +.. } & \multirow[t]{2}{*}{$0 .\{\wedge$} & 71 & $\Lambda .0$ & $\wedge$ & دنيا \\
\hline & & rVY & r & $\Lambda$ & عليا \\
\hline
\end{tabular}

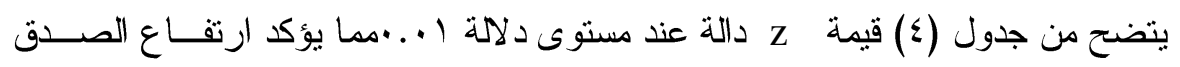
التمييزي للأختبار التحصيلي. ثنانياً : ثبات الاختبار : تم حساب ثبات الاختبار بطريقتين هما :

أ - طريقة ألفا كرونباك Alpha Cronbach Method

نم حساب ثبات الاختبار عن طريق معادلة ألفا كرونباك ، وبلغت قيمة معامـل ثبـــات

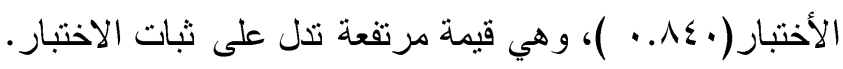




\section{ب - التجزئة النصفية لفقرات الاختبار:}

وللتأكد من ثبات الاختبار تم تجزئة فقراته إلى أسئلة فردية وأخرى زوجية ثـم حسـاب

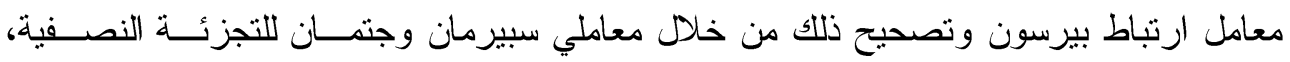

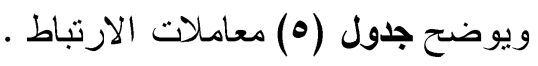

(ن) جدول (ن)

معاملات التجزئة النصفية للأختبار

\begin{tabular}{|c|c|c|c|}
\hline الالالة & معامل جتمان & معامل سبيرمان & الخواص \\
\hline$\ldots 1$ &. .9 .1 & .9 .4 & الاختبار \\
\hline
\end{tabular}

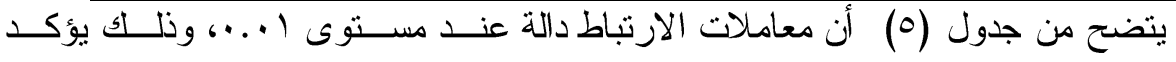

ثبات الاختبار .

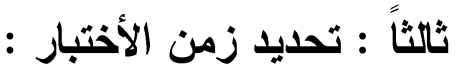

تم حساب زمن تطبيق الاختبار عن طريق رصد الوقت الذي استغرقته أول معلمة والـــي

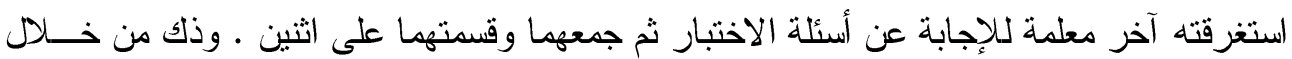
المعادلة الثالية : زمن انتهاء أول معلمة + زمن انتهاء آخر معلمة

متوسط زمن الأختبار

متوسط زمن الأختبار =

رابعاً : معامل السهولة والصعوبة لمفردات الاختبار :

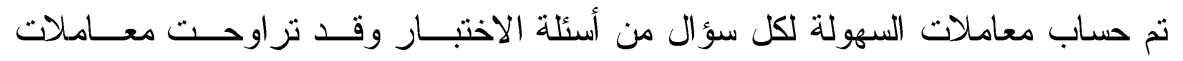

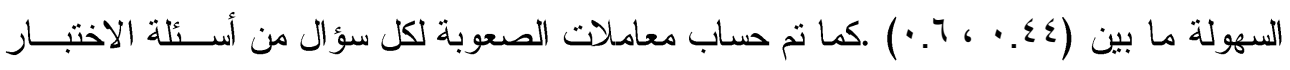

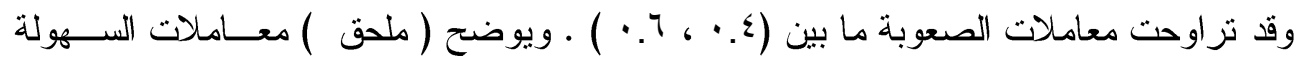

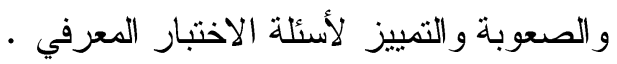




\section{r- إعداد البرنامـج التدريبي المقترح :}

الخطوات المتبعة لإعداد البرنامج المقترح :

$$
\begin{aligned}
& \text { أ- أسس بناء البرنامج . }
\end{aligned}
$$

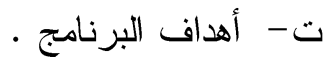

جـ- - خطوات إعداد محتوى البرنامج •

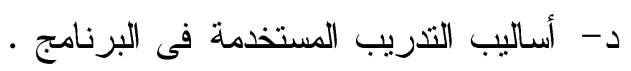

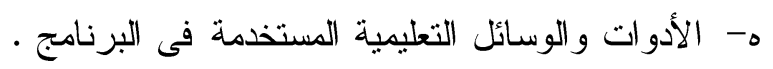

$$
\begin{aligned}
& \text { و - نقويم البرنامج . الادول }
\end{aligned}
$$

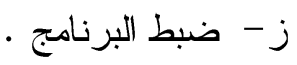

وسيتم فيما يلي شرح الخطوات السابقة بالتفصيل :

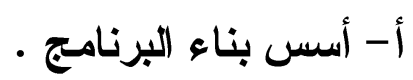

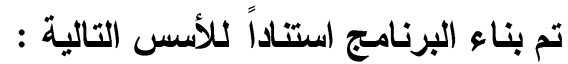

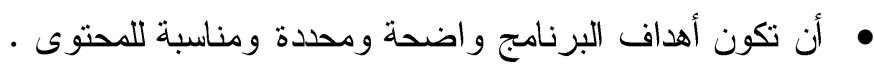

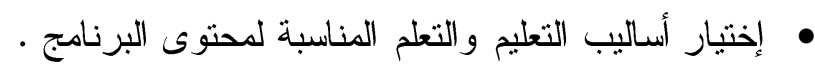

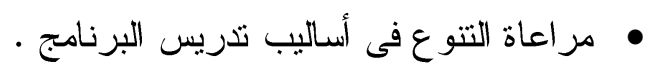

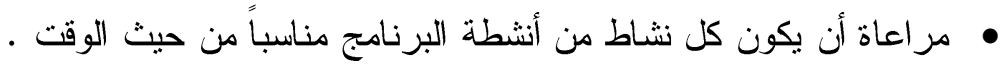

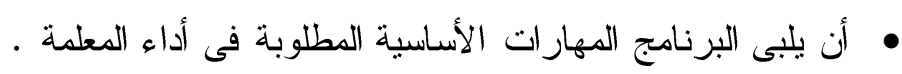

• مراعاة مبدأ الو اقعية بحيث تكون الخطة الموضوعة للبرنامج فى حدود الإمكانات الفعلية .

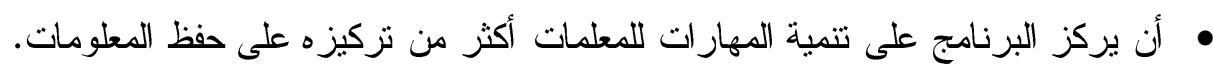

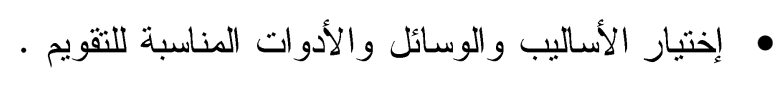

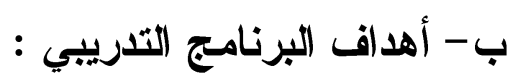

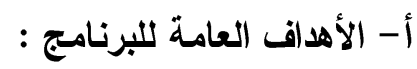

1 - تعريف المعلمات بمفهوم اضطرابات النطق وأسبابها ومظاهر ها والتمبيز بينها .

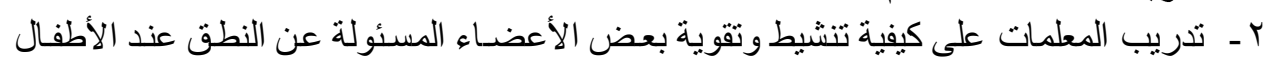

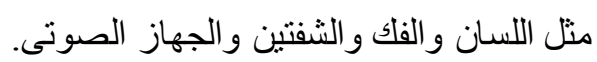

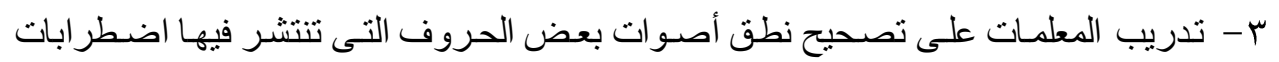
النطق بين أطفال الروضة. 


\section{ب - صياغة الأهداف العامة فى صورة أهداف سلوكية :}

تم ترجمة كل هدف عام الى مجموعة من الأهداف الســلوكية (الإجرائيــة )التــي تمثـلـل

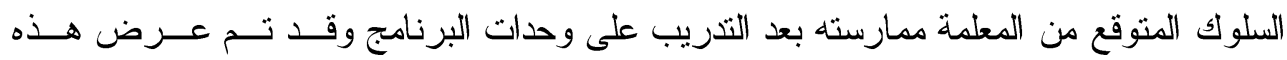

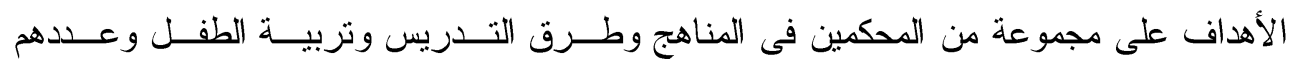

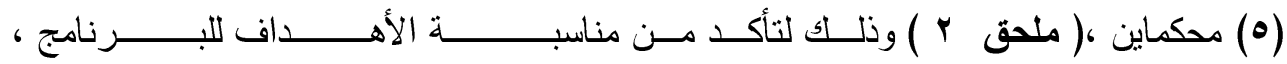

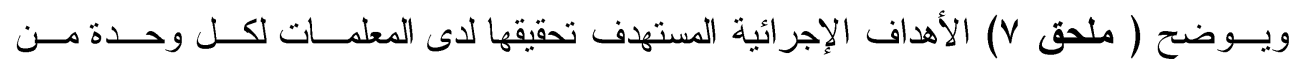

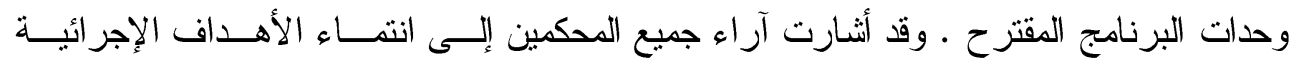

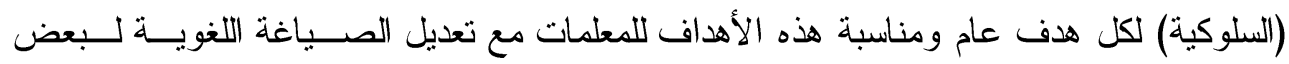

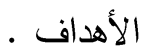

ج- خطوات إعداد محتوى البرنامج :

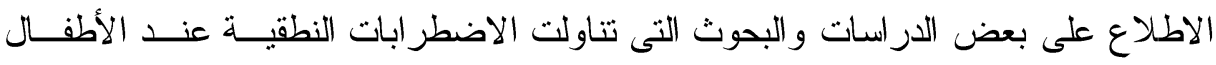

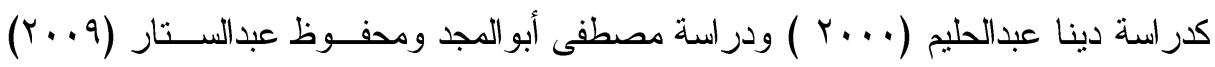

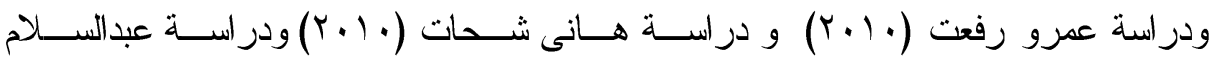

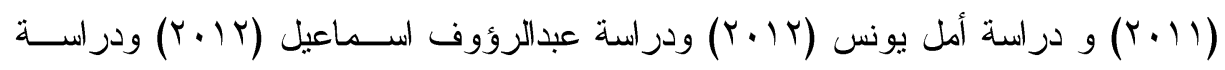

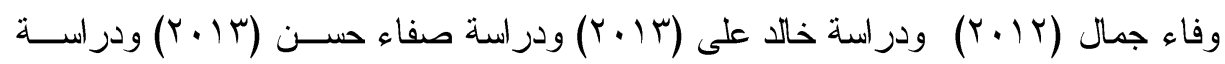

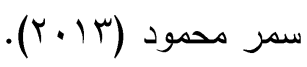

الاطلاع على بعض الدراسات التي اهتمت بتدريب معلمات رياض أطفال علـى مهــارات

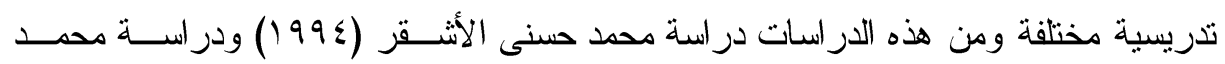

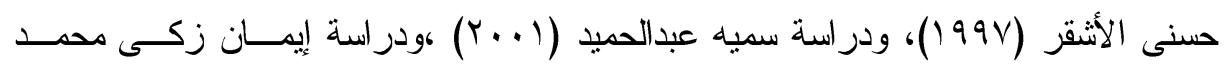

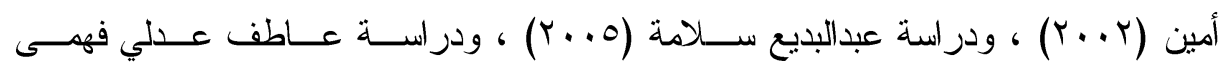

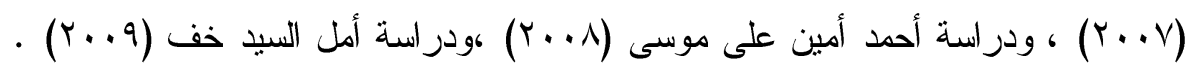

وقد تم تحديد محتوى البرنامج وفقاً للمعاير التالية : ارتباط المحتوى بأهداف البرنامج التى يسعى إلى تحقيقها . دقة المحتوى وسلامته اللغوية . دقة المحتوى وسلامته العلمية . مناسبة أساليب التقويم المستخدمة لقياس الأهداف السلوكية للبرنامج .

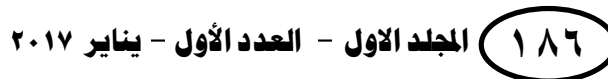


وقد تم تحديد محتوى البرنامج بحيث تضمن البرنامج ثلاث وحدات :

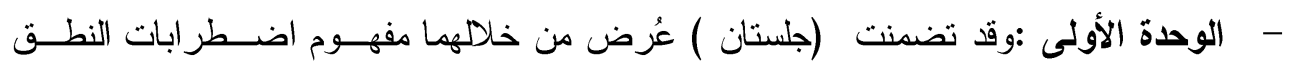

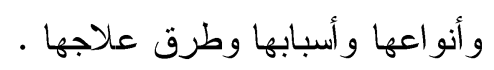

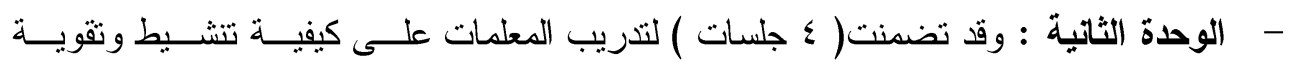
بعض الأعضاء المسئولة عن النطق عند الأطفال وهى اللسان والفلك و الثــفتبن والجهــاز • الصوتى الاعنى

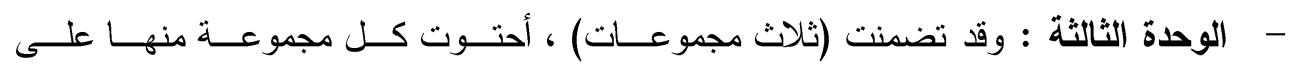
(0 جلسات) لتدريب المعلمات على تصحيح نطق أصوات بعض الحروف التى تنتشر فيها

اضطر ابات النطق بين أطفال الروضة .

د - أساليب التّريس المستخدمة فى البرنامج :

تم استخدام بعض الأساليب المتتوعة للندريب على البرنامج ومنها :-

ا

وتستخدم لتزويد المعلمات المندربات بالمعلومات اللازمة حول موضوعات البرنامج •

r-|لمناقشة :

وقد أجريت مناقتشات حول موضوعات البرنامج وأهيتها ، قبل البدء فى تتفيـــ الأنثــــة

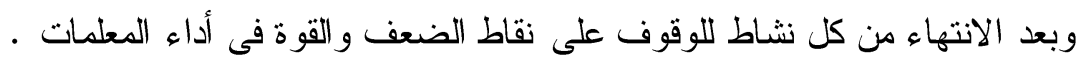
r- (التعلم الأتى : n

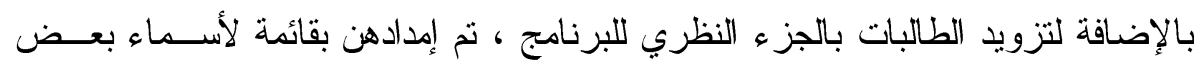

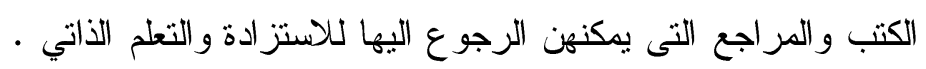

ع - التدريس المصغر :

تم استخدام التذريس المصغر لتدريب المعلمات وفيه تقــوم إحـدى المعلمــات بالتــدريس

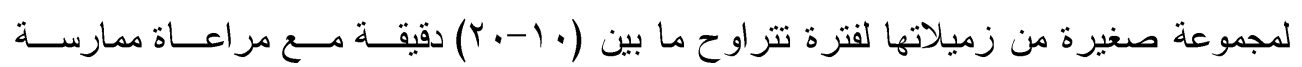
المهار ات المقصود التذريب عليها. 
ويساعد أسلوب ورش العمل على توفير فرص التدريب على التعاون الجماعي والاثــنزاك

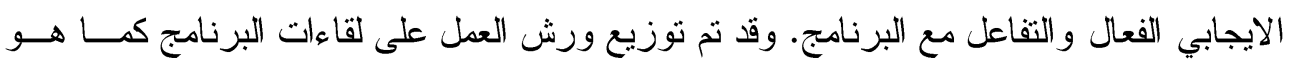

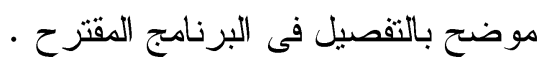

ه- الأدوات والوسائل التعليمية :

- Data Show استخدام الـ-

- كتب ومراجع - CD - صور ورسومات .

- مقاطع فيديو لكيفية نطق بعض الحروف.

- استخدام عروض Power Point.

$$
\text { و - تقويم البرنامج : }
$$

استخدمت الباحثة أساليب التقويم التالية :

$$
\text { - التقويم القبلي : }
$$

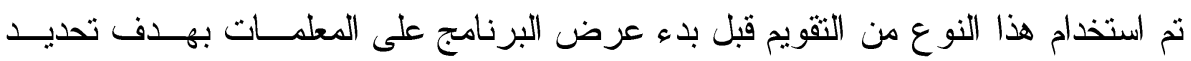

المستوى القبلي لهن وذلك لمعرفة مدى إلمامهن بالمهارات التى يهدف البرنامج الى تتميتها لــديهن

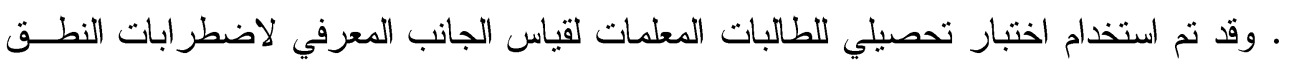

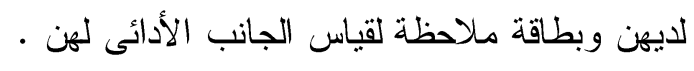
- التقويم التكويني :

وقد تم استخدام هذا النوع من التقويم أثناء عرض البرنامج علــى المعلمـات المتـدربات

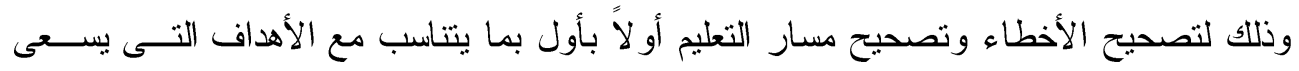

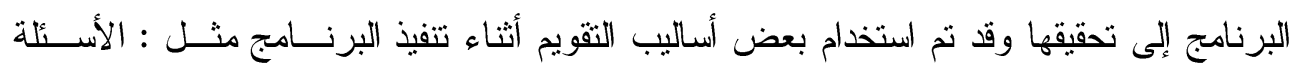

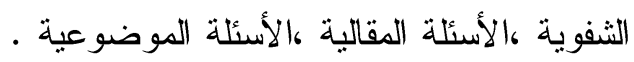


- التقويم النهائي -

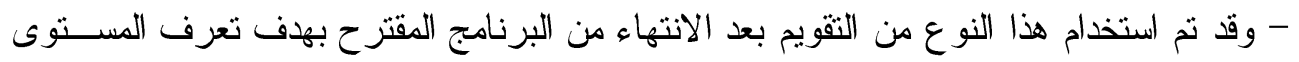

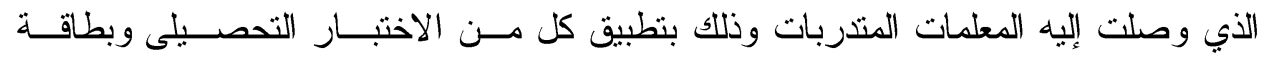

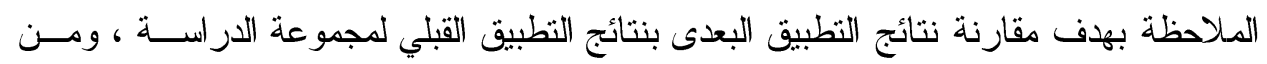

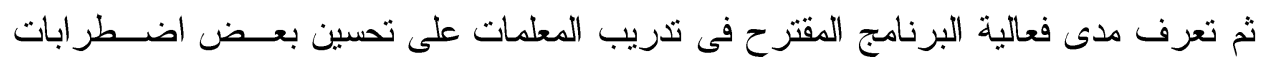
النطق لدى أطفال الروضة فعالية البرنا

- كما كانت تستخدمه الباحثة بعد نهاية كل لقاء من لقاءات البرنامج ويتم تقيـيم المعلمــات بنــاء

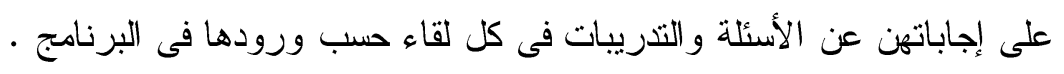

ز - ضبط البرنامج :

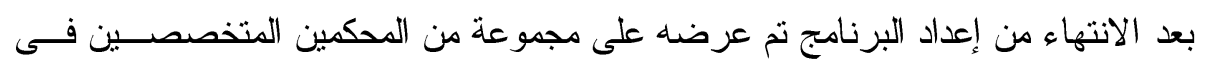

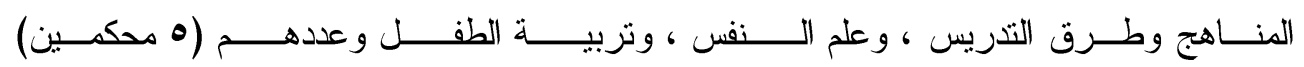

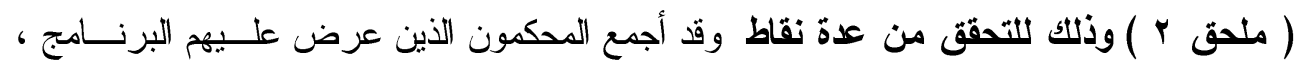

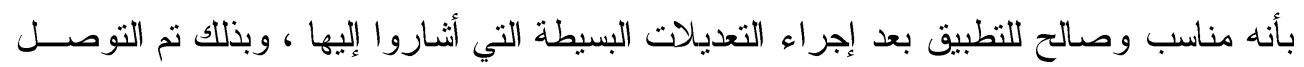

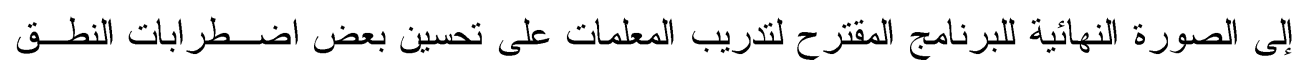

$$
\begin{aligned}
& \text { لاى أطفال الروضة ، (ملحق ^ ^ ) . } \\
& \text { ثانياً : تثفيذ تجربة البحث : }
\end{aligned}
$$

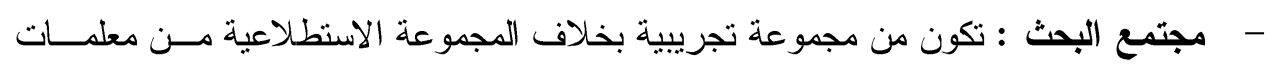

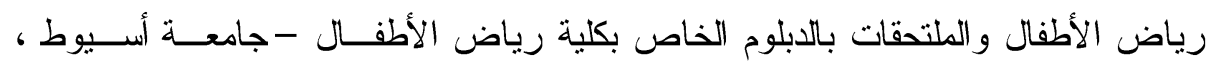

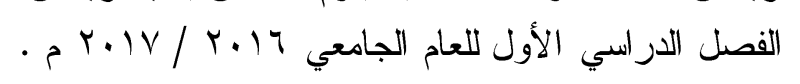

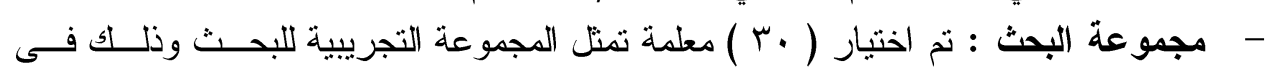

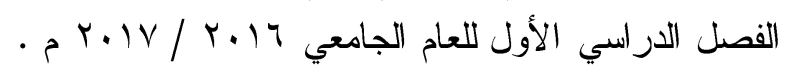

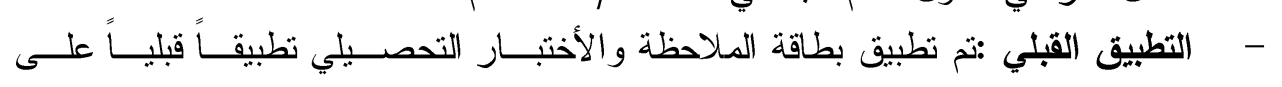

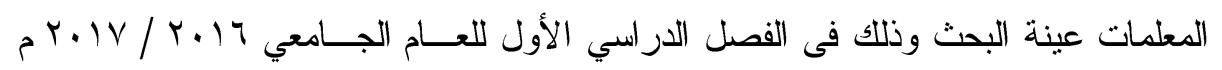
ورصد النتائج. - - تطبيق البرنامج : تم تطبيق البرنامج التذريبي وذلك فــى الفصــل الدراســي الأول للعــام

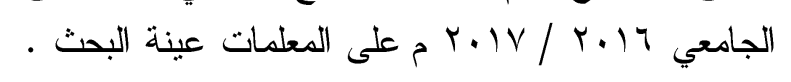

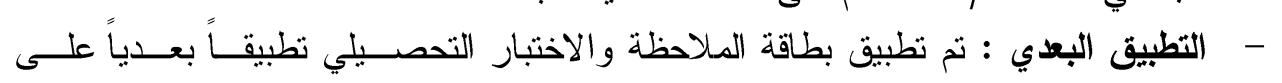

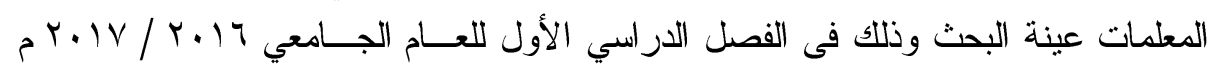
ورصد النتائج · لمعين 


\section{نتائج البحث وتفسيرها :}

للتحقق من صحة الفرض الأول والأى نصه "توجد فــروق ذات دلالـــة إحصــائية بــين

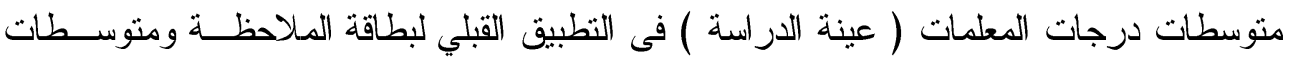

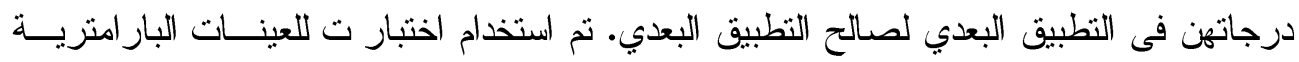

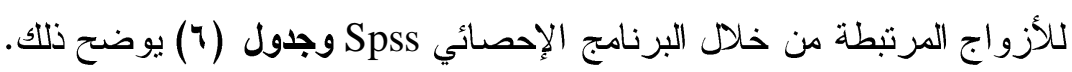

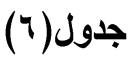

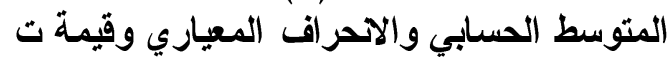

ومستوى الالالة للفروق بين متوسط درجات المعلمات قبل وبعد تطييق بطاقة المـلاحظة

\begin{tabular}{|c|c|c|c|c|c|c|}
\hline مستوى اللالة & قيمة ت & المعياري & الحسابويط & العلد & التطبيق & البطاقة \\
\hline \multirow{2}{*}{ دال عنـــــــ } & \multirow{2}{*}{ 1. } & $1 . V \cdot \Delta T V$ & 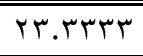 & $r$. & قبلي & \\
\hline & & 1...4r. & ON.VYTV & r. & بعدي & الحلي \\
\hline
\end{tabular}

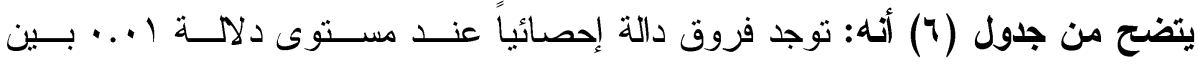

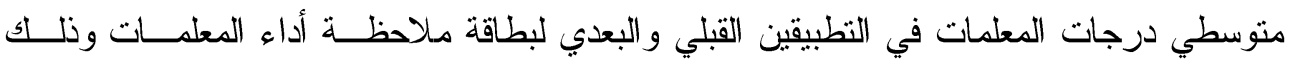
لصالح متوسط درجاتهن في النطبيق البعدي.

ويتضح من نتائج الفرض الأول أن هناك تحسناً ملحوظاً في أداء المعلمات مــع الأطفــال

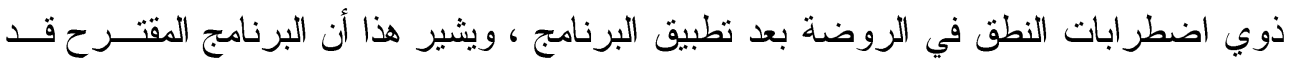

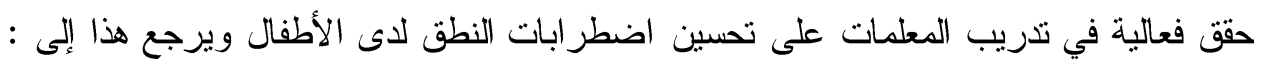
- - - أساليب التنريس و التدريب التي استخدت في البرنامج ·

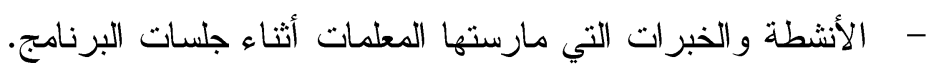

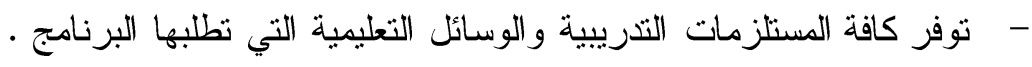
و هذه النتيجة تنفق مع ما توصلت الليه بعض الدراسات السابقة التـى اســتهدفت تـدريب

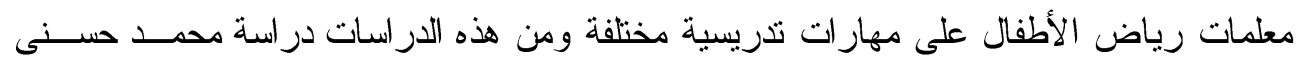

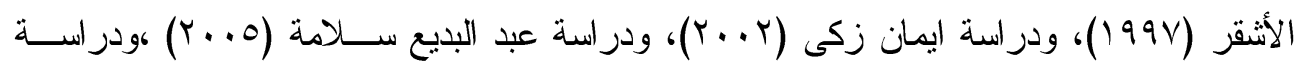

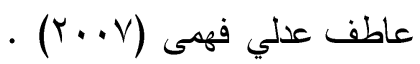




\section{المجلة العلمية لكلية رياض الاطفال - جامعة اسيوط}

للتحقق من صحة الفرض الثاني والذى نصه "'" توجد فروق ذات دلالـــة إحصــائية بــين

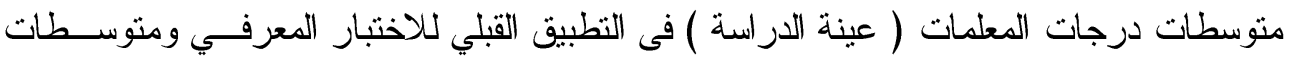

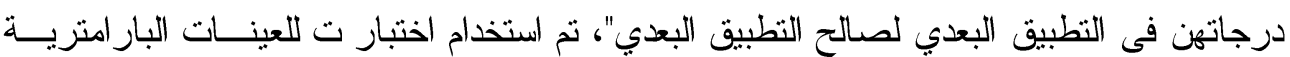

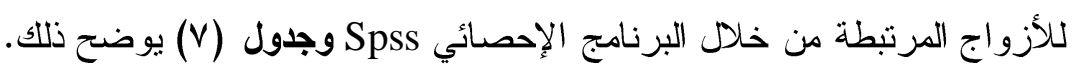

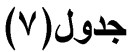

المتوسط الحسابي والاحراف المعياري وقيمة ت ومستوى الالالة للفروق بين

متوسط درجات المعلمات قبل وبعد تطبيق الاختبار

\begin{tabular}{|c|c|c|c|c|c|c|}
\hline الادلاةتوى & قيمة ت & الانعرياري اف & المتوسط إبح & العدد & التطبيق & الأبعاد \\
\hline \multirow{2}{*}{ دال عند } & \multirow[b]{2}{*}{ rV.IT } & $1.7 \cdot V$ & $7.977 \mathrm{~V}$ & r. & قبل & \multirow{2}{*}{ البعد الأول } \\
\hline & & $.9 \cdot V$ & IN.KYTV & $r$ & بعدي & \\
\hline \multirow{2}{*}{ دال عند } & \multirow{2}{*}{$r \leq .9 \mathrm{~V}$} &..$\wedge \wedge 7$ & r.A... & $r$. & قيل & \multirow{2}{*}{ البعد الثاني } \\
\hline & &.$V T$ & $9.0 T r \mu$ & $r$. & بعدى & \\
\hline \multirow{2}{*}{ دال عند } & \multirow{2}{*}{ TY.VI } &. .791 & ח וسזA. & r. & قبل & \multirow[t]{2}{*}{ البعد الثالث } \\
\hline & & $\cdot . \wedge \wedge 7$ & A.r... & $r$. & بعدى & \\
\hline \multirow{2}{*}{ دال عند } & \multirow{2}{*}{ OY.VO } & Y.roV & $1 Y .7 \ldots$ & r. & قبل & \multirow{2}{*}{ الكلبة جة } \\
\hline & & 1.0 .1 & ז..... & $r$. & بعدي & \\
\hline
\end{tabular}

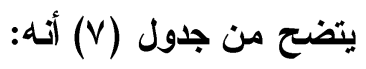

- توجد فروق دالة إحصائياً عند مستوى دلالة ا +.. بين متوســي درجـات المعلمــات فـي

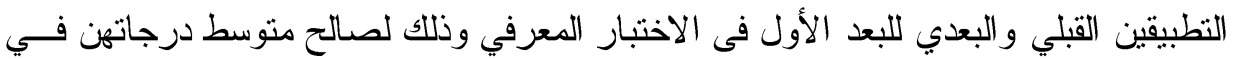

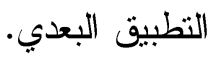

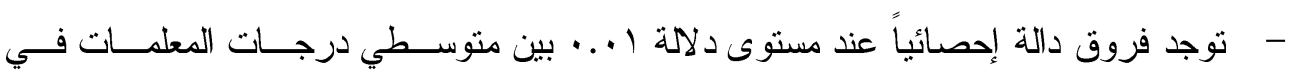

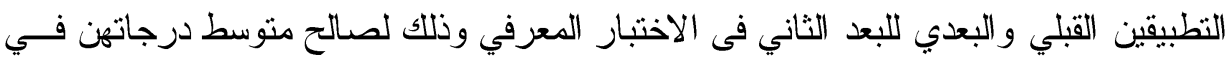

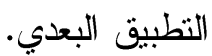

- - توجد فروق دالة إحصائياً عند مستوى دلالة ا ... بين متوسـطي درجـات المعلمـات فـي التطبيقين القبلي و البعدي للبعد الثالث فى الاختبار المعرفي وذلك لصالح متوسط درجاتهن فـي لـي النطبيق البعدي.

- توجد فروق دالة إحصائياً عند مستوى دلالة ا ... بين متوســـي درجــات المعلمــات فـي

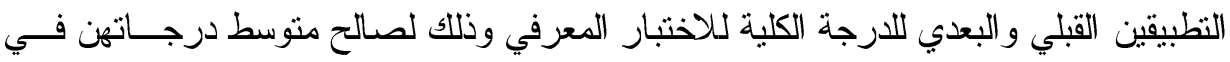

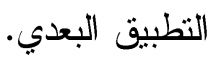


يتضح من نتائج الفرض الثاني إلمام المعلمات بالجانــب المعرفـي المُتضـــن فـي البرنامج ويرجع ذلك إلى : لتصن

- - احتو اء الإطار النظري للبرنامج على قدر كبير مــن المعلومــات والمعــارف المتعلقــة باضطر ابات النطق عند الأطفال . الإطار

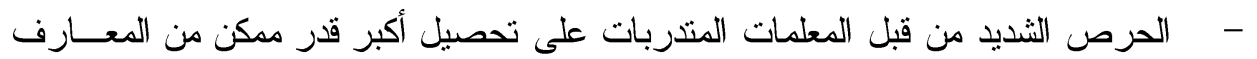

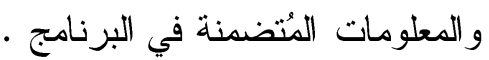

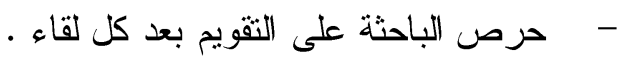

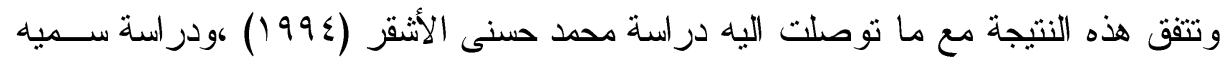

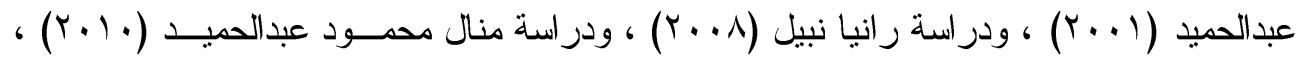
ودر اسة نهى مرتضى ( (r. (r ) ).

للتحقق من صحة الفرض الثالث والأي نصه " توجد فاعلية للبرنامج المقترح في تـدريب

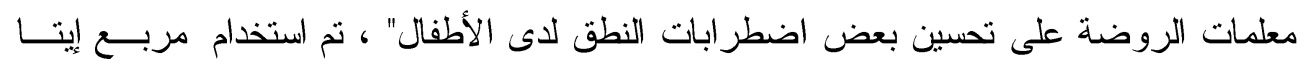

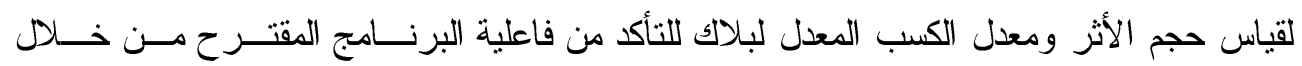
البرنامج الاحصائي Spss وجدول (^) يوضح ذلك.

\section{جلول(^)}

المتوسط الحسابي والاحمراف المعياري وقيمة ت وحجم الأثر ومعدل بلاكو لأدوات البحث

\begin{tabular}{|c|c|c|c|c|c|c|c|c|}
\hline الالامة & معل & مربـــع & قيمة T & 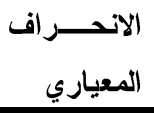 & الأمتوســــ & العدد & التطبيق & الأبعاد \\
\hline \multirow{2}{*}{ كبيز } & \multirow{2}{*}{1.07} & \multirow{2}{*}{.999} & \multirow{2}{*}{ I. } & 1.V.人 V V & rr.rrrr & $r$. & قبلي & \multirow[t]{2}{*}{ بطاقة الملاحظة } \\
\hline & & & & 1...4r. & 01.VTiV & $r$. & بعدي & \\
\hline \multirow{2}{*}{ كبير } & \multirow{2}{*}{$1 . \varepsilon r$} & \multirow{2}{*}{$\because 91$} & \multirow{2}{*}{ rv.Ir } & $1.7 . v$ & 9.9748 & $r$. & قبلي & \multirow{2}{*}{ الاختبار المعرفي } \\
\hline & & & & $\therefore .9 . v$ & 11. & $r$. & بعدي & \\
\hline \multirow{2}{*}{ كبير } & \multirow{2}{*}{1.0} & \multirow{2}{*}{.99} & \multirow{2}{*}{$Y \leqslant .9 V$} & $\because \wedge \wedge \bar{T}$ & r.^... & $r$. & قبلي & \multirow{2}{*}{ الاختبار المعرفي } \\
\hline & & & & $\therefore V r$. & 9.orrr & $r$. & بعدي & \\
\hline \multirow{2}{*}{ كبير } & \multirow{2}{*}{$1 . \varepsilon Y$} & \multirow{2}{*}{$\because 9 \mathrm{~V}$} & \multirow{2}{*}{ HY.VI } & .991 & 1. 1. & $r$ & قبلي & \multirow{2}{*}{ الاختبار المعرفي } \\
\hline & & & & $\because \wedge \wedge \bar{T}$ & $\Lambda . r \ldots$ & $r$. & بعدي & \\
\hline \multirow{2}{*}{ كبير } & \multirow{2}{*}{$1 . \varepsilon \varepsilon$} & \multirow{2}{*}{$\because 99$} & \multirow[t]{2}{*}{ OY.Vo } & r.rov & Ir.7... & $r$. & قبلي & \multirow{2}{*}{ كلاختبار المعرفي } \\
\hline & & & & $1.0 \cdot 1$ & r... & $r$. & بعدي & \\
\hline
\end{tabular}




\section{يتضح من جدول (^) ما يلي:}

- قيمة حجم الأثر كبيرة لكل من بطاقة الملاحظة والاختبار المعرفي، وذلك يؤكســ اسـتمر ارية البرنامج في تأثيره على المعلمات.

- معدل بالاك لكل من بطاقة الملاحظة والاختبار المعرفي أكبر من النسبة التي حسدها بــلاك

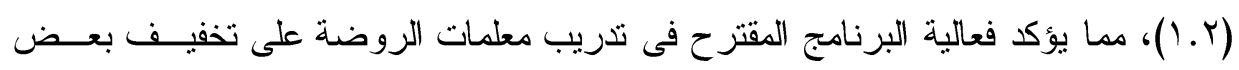

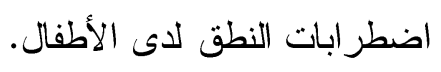

- - و هذه النتيجة تتقق مع ما توصلت اليه بعض الدراسات السابقة والتى أكدت فاعليـــة البــرامج

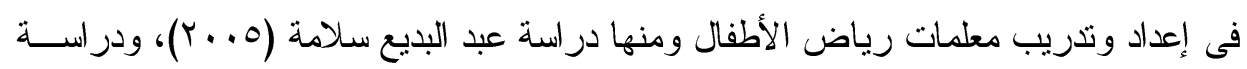

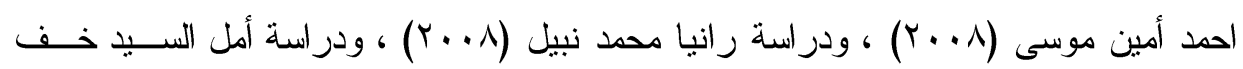

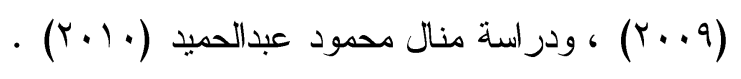

- المعالجة الإحصائية:

للتحقق من كفاءة أدوات البحث السيكومترية، وصحة الفروض، استخدمث الباحثة عدداً مسنـ الأساليب الإحصائية، منها :

1- اختبار " مان ويتني " لحساب دلالة الفروق الإحصائية بــين المجموعـات الــنيا والعليــا بالمقاييس.

r- دعادلات التجزئة النصفية وألفا كرونباك للتحقق من ثبات المقاييس. r- المتوسطات الحسابية والإنحر افات المعيارية.

ع - اختبار " ت " لحساب دلالة الفروق الإحصائية بين أزواج المجموعات المرتبطة. 0- معادلة حجم الأثر، للتأكد من فعالية البرنامج التدريبي. 


\section{توصيات البحث :}

\section{فى ضوء ما سبق يوصي البحث بالآتي :}

* عقد ندوات ومحاضرات وورش عمل للمعلمــات و الموجهــات وأوليــاء الأمــور لتعـريفهم

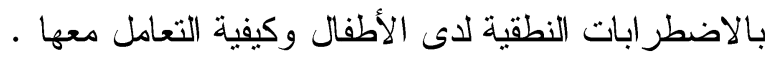
" إجر اء المزيد من الدراسات والبحــوث حـول تــدريب الأمهــات و المعلمــات علـى عـلاج الاضطر ابات النطقية لدى الأطفال .

* إعداد دليل لمعلمات رياض الأطفال يستعن به فى الروضة وذلـــك لتعـريفهن بالاضـــر ابات

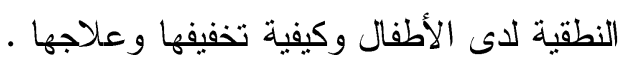

\section{الار اسات والبحوث المقترحة :}

فيما يلى بعض المقترحات والاراسات المستقبلية ذات الصلة بالدراسة الحالية : 1- برنامج مقتر حلندريب الأمهات وأولياء الأمور على علاج اضطر ابات النطق لاى الأطفال. ץ- برنامج مقترح لتدريب معلمات الأطفال المكفوفين على خفض بعـض اضـــر ابات النطـق لديهم

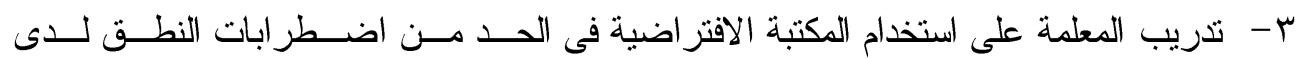

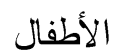




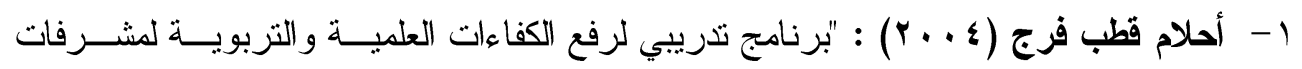

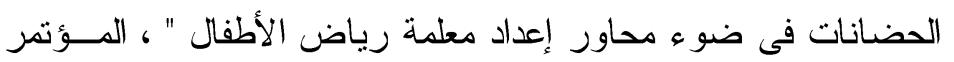

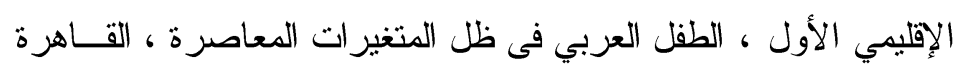

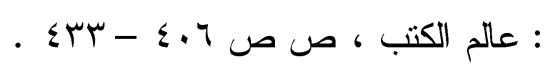

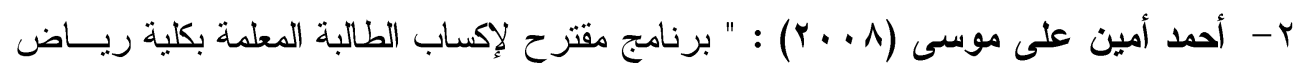

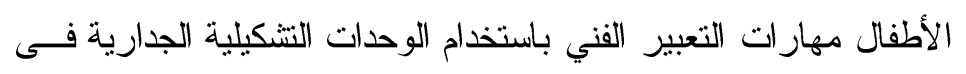
الروضة " ، رسالة دكتور راه ، كلية رياض الأطفال ، جامعة القاهرة . r- أحمد صبري ومحمد صبري (Y 1 • ץ): صعوبات التعلم، القاهرة : دار المعارف الجامعية.

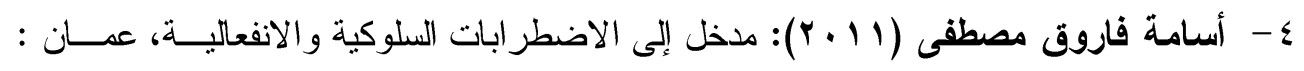

$$
\text { دار المسيرة. }
$$

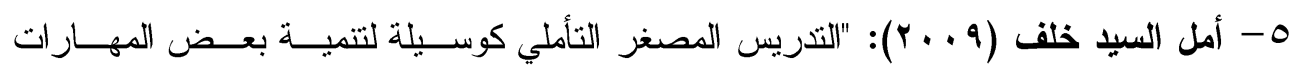

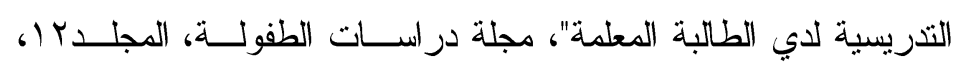

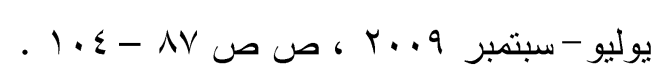

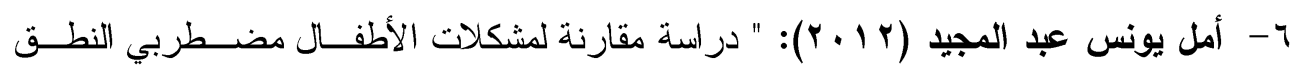

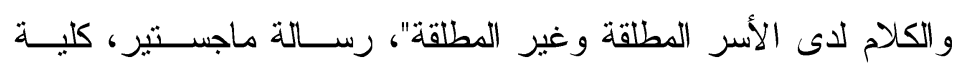
الخدمة الاجتماعية، جامعة حلوان.

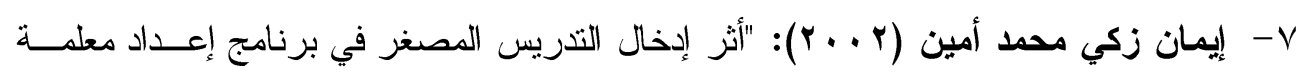

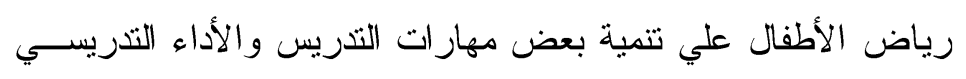

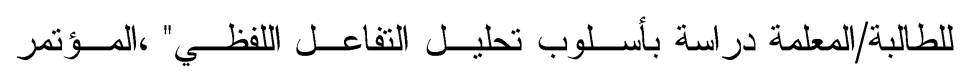

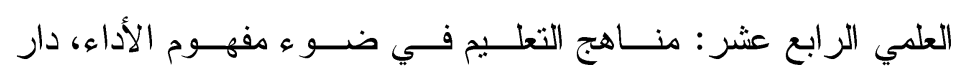

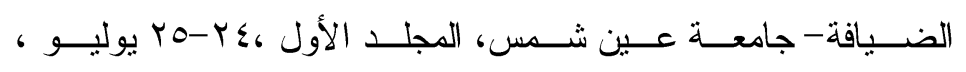

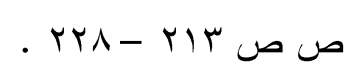

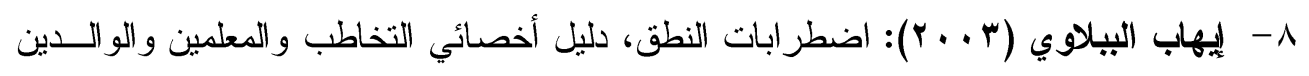
، القاهرة: مكتبه النهضة المصرية. 
9- جابر عبد الحميد و أحمد خيري كاظم ( ) : مناهج البحث في التربية وعلم الـنفس ،

$$
\text { القاهرة : دار النهضة العربية . }
$$

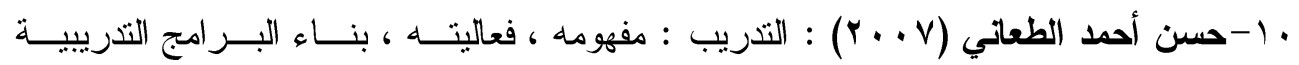

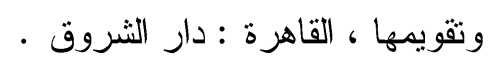

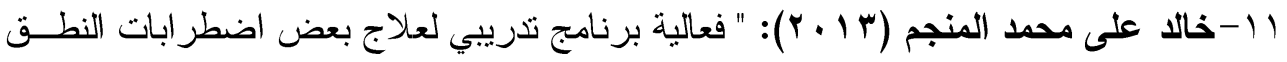

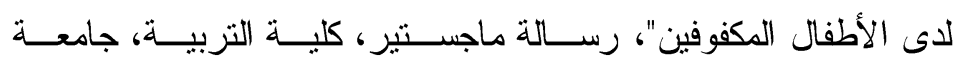

$$
\text { عين شمس. }
$$

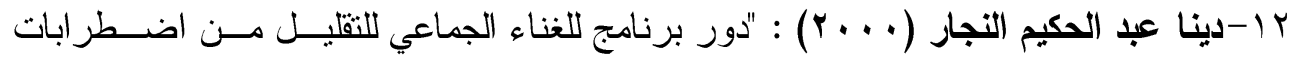
النطق لدى المتخلفـين عقليــا"، رســالة ماجســتير، كليــة التربيــة ،

$$
\text { جامعة حلوان. }
$$

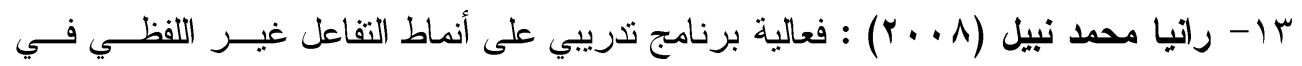
اكتساب معلمات رياض الأطفال لهذه الأنماط واســتخدامهن لهــا فـي لــي

$$
\text { التدريس " ، رسالة ماجستير ، كلية التربية ، جامعة أسيوط. }
$$

ـ ا- زينب رفت زكي (0 + . r) : " برنامج مقترح لترريب معلمات رياض الأطفال على علاج

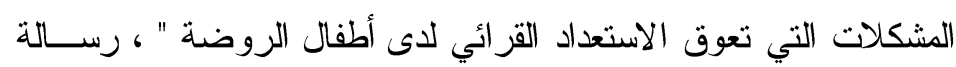

$$
\text { ماجستير ، كلية التربية ، جامعة أسيوط. }
$$

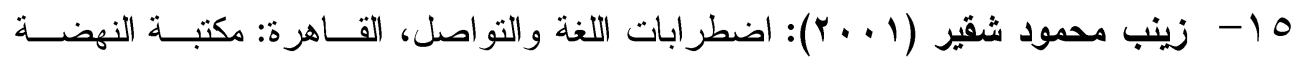

$$
\text { المصرية. }
$$

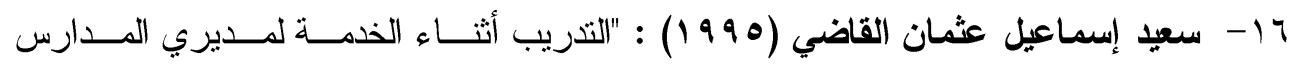

در اسة ميدانية لبعض مشكلات المتدربين بكليــة المعلمــين " ، المملكــة

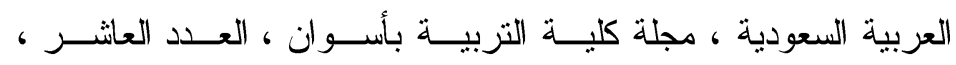

$$
\text { ص ص ص }
$$

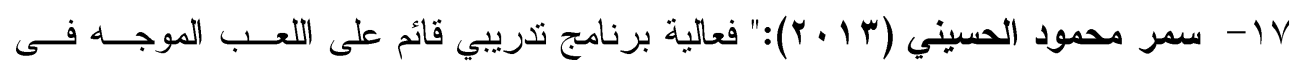
خفض بعض اضطرابات النطق لدى أطفال الروضة"، رسالة ماجستير، كلية التزبية، جامعة الزقازيق. 
11- سميرة أبوزيد عبده وسحر توفيق نسيم (ع . . ץ): دليل المعلمة لأنشطة رياض الأطفــال،

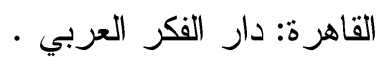

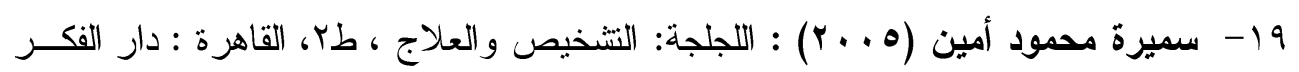
العربي.

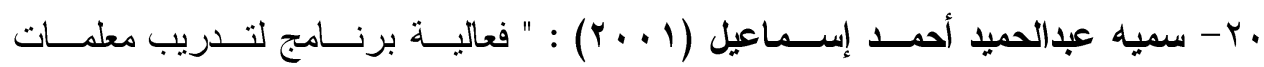

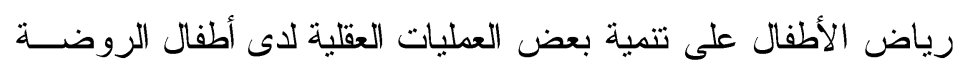

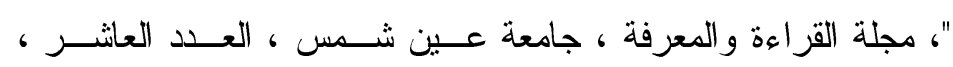

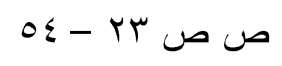

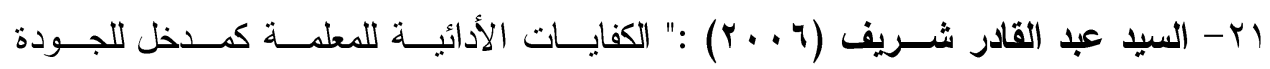

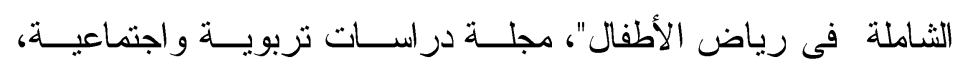

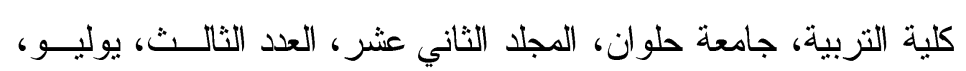

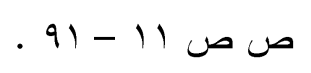

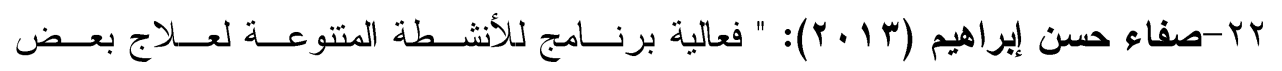

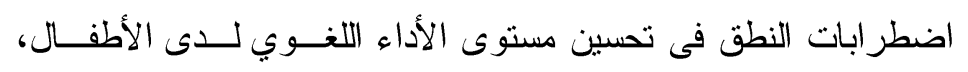

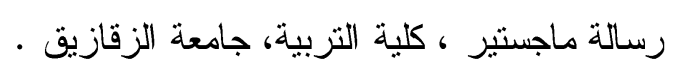

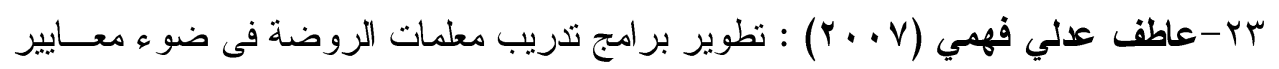

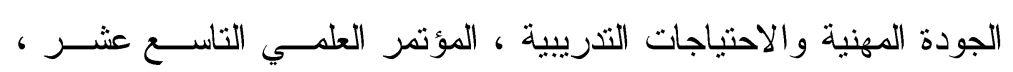

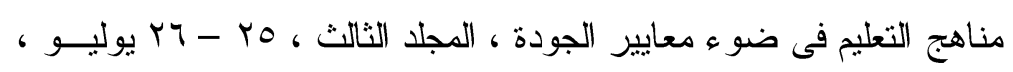

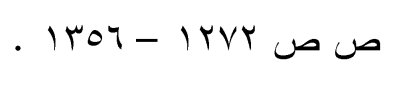

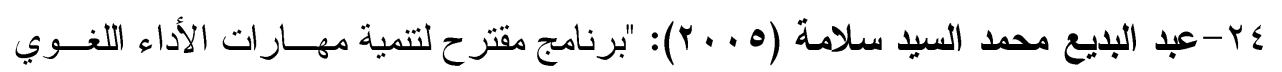

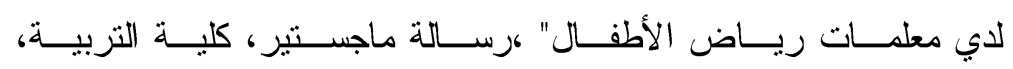
جامعة المنصورة

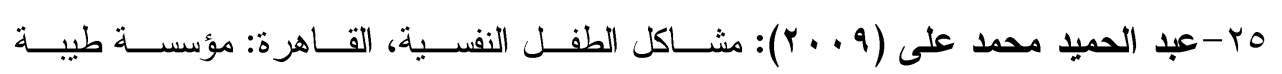

$$
\text { للنشر و التوزيع. }
$$

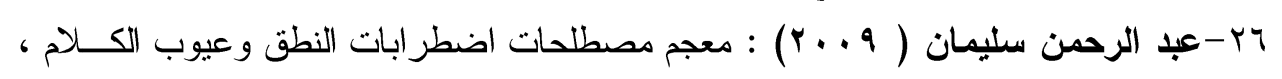
القاهرة: مكتبة الأنجلو المصرية. 


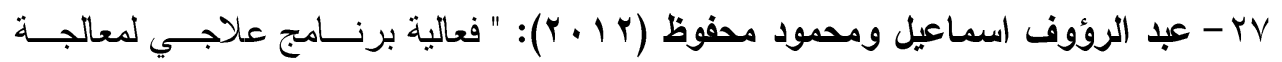

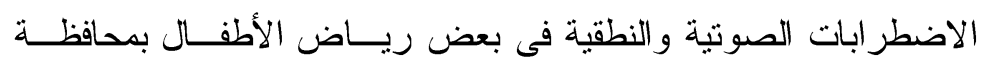

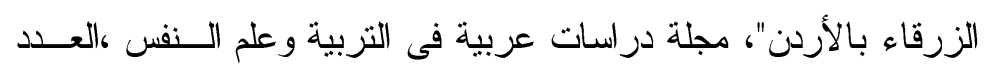

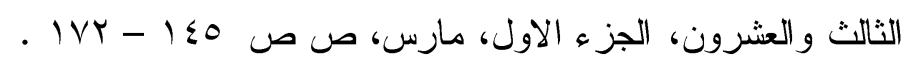

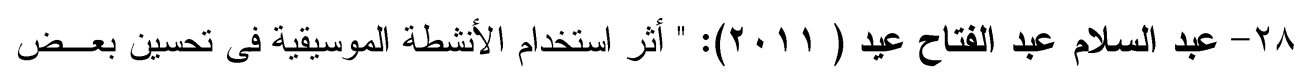

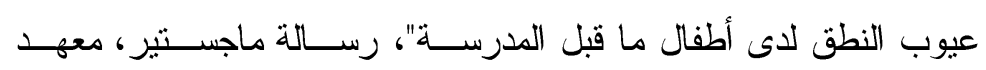

الدارسات و البحوث التربوية، جامعة القاهرة.

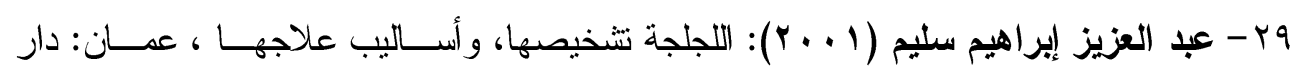

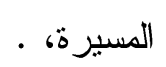

• ب- عبد العزيز السيد الشخص(؟ . . r) : اضطر ابات النطق و الكلام (خلفيتها - تشخيصــها -

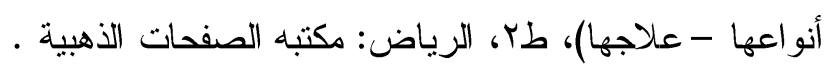

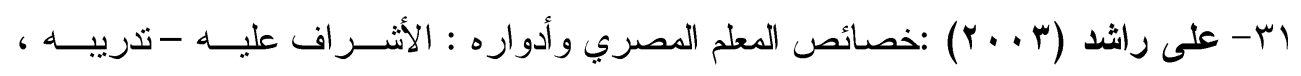

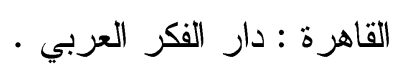

rس- عمرو رفعت عمر ( ( + r) :" فعالية برنامج تدريبي علاجي للحد من اضطر ابات النطــق

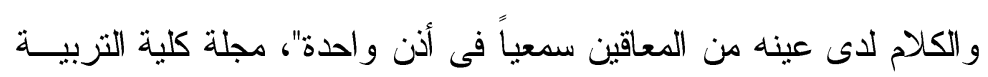

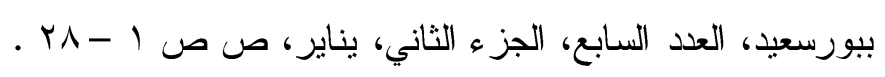

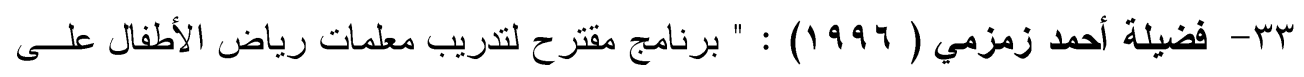

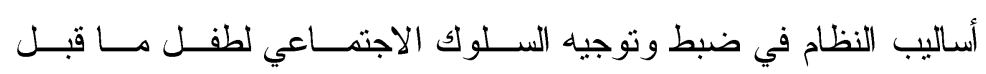

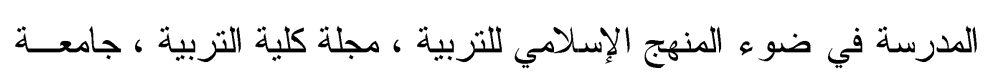

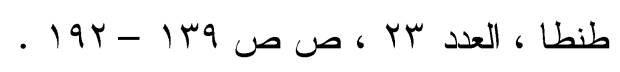

ع - كريمان بلير (ع . r) : استراتيجيات تعليم اللغة برياض الأطفال، القاهرة: عالم الكتب.

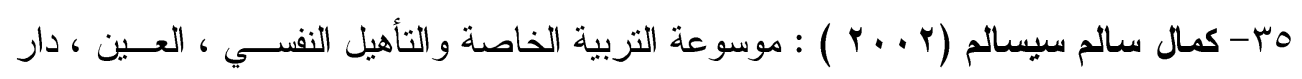

$$
\text { الكتاب الجامعي }
$$

بس- مجدى أحمد محمد عبد الله (ع + . ץ): الاضطر ابات النفسية للأطفال الأغراض والأســباب

$$
\text { و العلاج، القاهرة: دار المعرفة الجامعية. }
$$




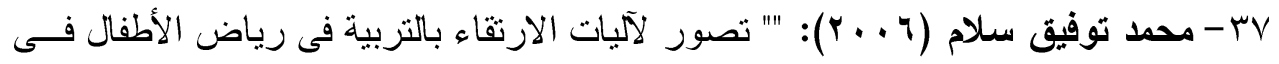

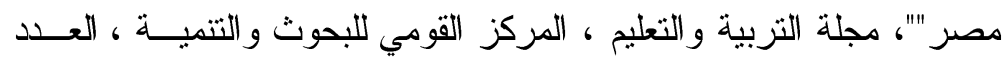

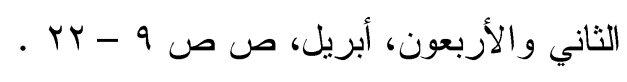

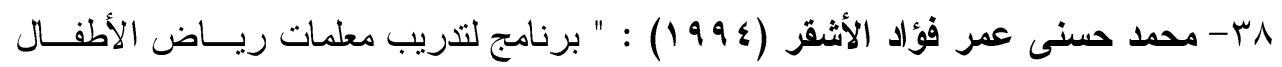

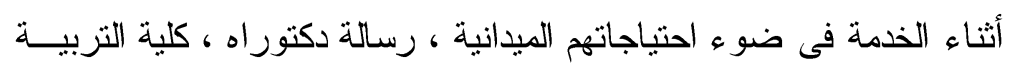

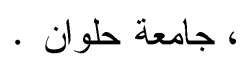

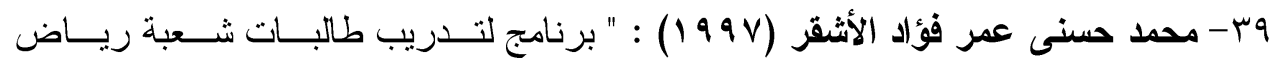
الأطفال على إنتاج الألعاب التربوية واستخدامها " ، التعليم من اجل مستقبل

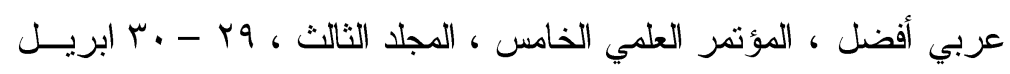

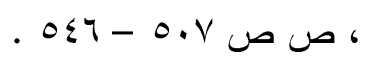

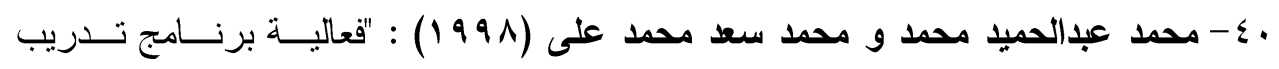

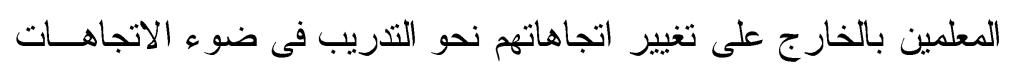

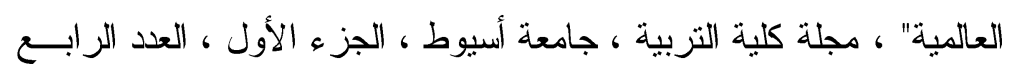

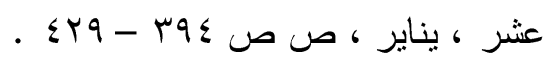

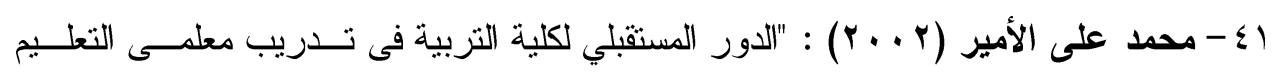

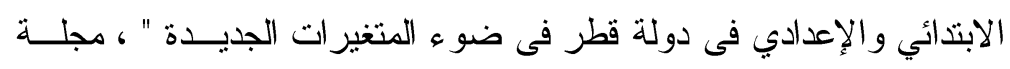

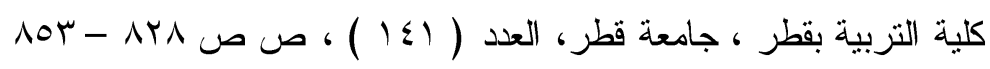

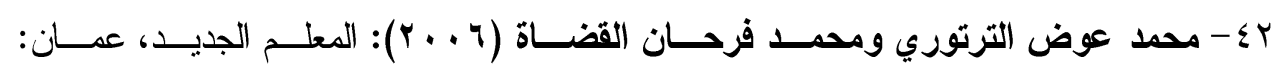
دار الحامد.

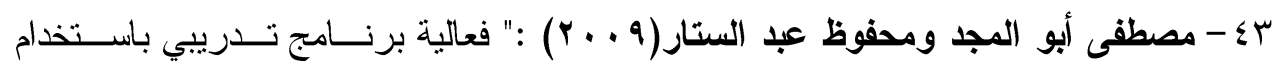

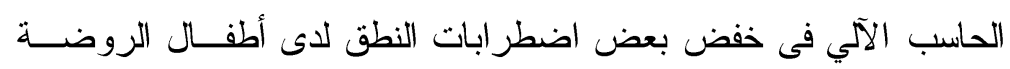

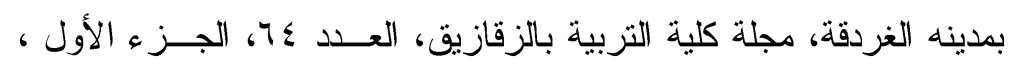

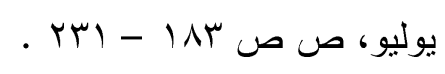

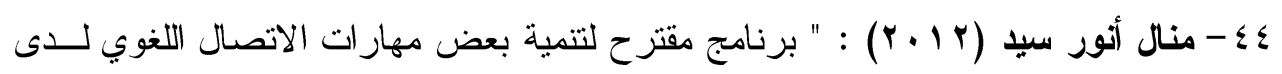

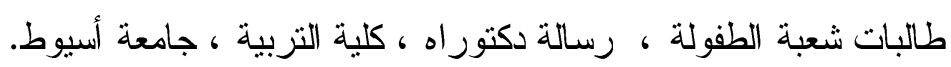

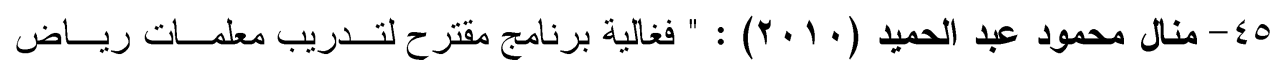
الأطفال على بعض مهارات التخطيط و التنفيذ و التقويم المستخدمة في تقــيم 
الأنشطة القصصية لأطفال الروضة ، رسالة دكتور اه ، كليــة التربيـة ،

$$
\text { جامعة أسيوط. }
$$

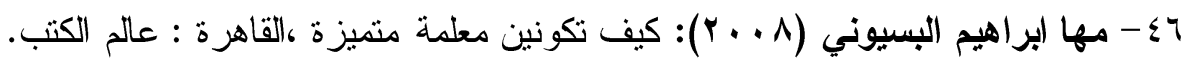

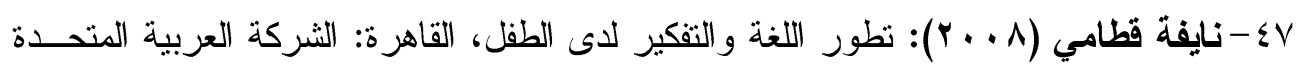

$$
\text { التسويق و التوريدات . }
$$

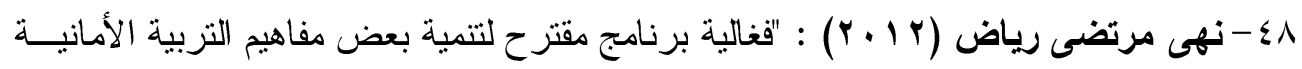

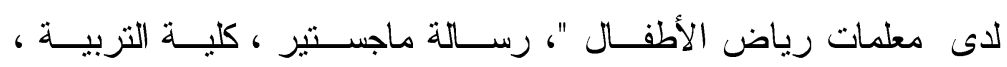

$$
\text { جامعة أسيوط. }
$$

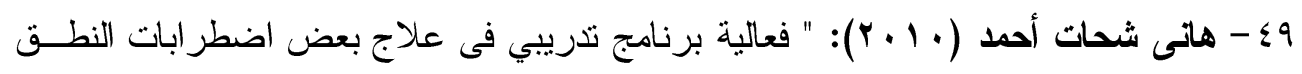

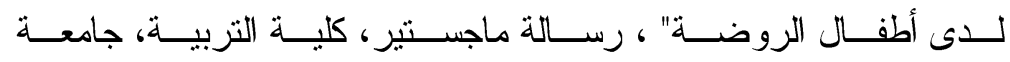

$$
\text { جنوب الوادي. }
$$

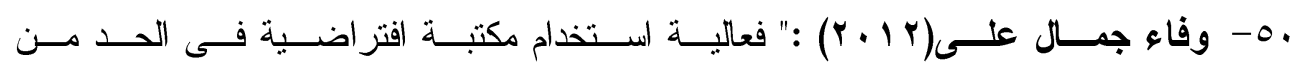

بعض اضطر ابات النطق و اللغـــة لـدى الأطفــال المضــــربين لغويـــا"،

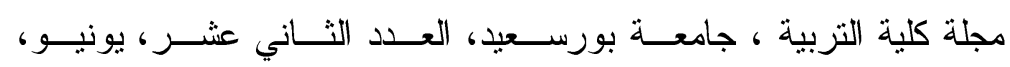

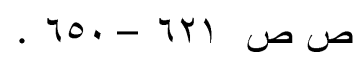

51- Angela .M, Kyriaki .T, Angela .P, Katherine. B, Cristina M (2017):

Who to Refer for Speech Therapy at 4 Years of Age Versus Who to "Watch and Wait"? , The Journal of Pediatrics, In Press, Corrected Proof, Available online 23 March 2017.

52- Bleile, K .M. (2003): Manual of articulation and phonological disorders: infancy through adulthood, (2th ed) Clifton Park, NY: Singular.

53- Dalton , A, Nadel, L, \& Rosenthal, D (2005) : Production of object words and action words, evidence for a relationship between phonology and semantics, Journal of Speech and Hearing Research, (28),323,330.

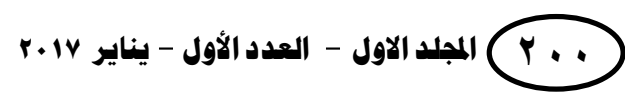




\section{المجلة العلمية لكلية رياض الاطفال - جامعة اسيوط}

54- Dockrell, J, Lindsay,G, Letchfotd,B \&Mackie,C, (2006): Educational Provision for Children with specific and language difficulties, perspectives of speech and language therapy service managers, International Journal of Language Communication Disorders ,41, (4), 423-440.

55-Felder, D, Hodabb,R , \& Elisabeth, M (2006): Co- articulation of lip rounding, Journal of Speech and Hearing Research, (11), $707-721$.

56- Gibson, D, (2003): Effects of grammar Facilitation on the phonological Performance of children with speech and language impairments, Journal of speech Research, (11), 707-721.

57- Gooze , J, Murdoch, B, Ozanne, A, Cheng, Y, Hill, A \& Gibbon, F (2007) : Lingual Kinematics and coordination in speechDisordered Children Exhibiting Differentiated Versus Undifferentiated Lingual Gestures, International Journal of Language \& Communication Disorders , 42(6) 703-724 .

58-Karrass ,J, Walden,T, Conture E, Graham,C, Arnold,H, Hartfield,k , \& Schwenk,k (2006) : Relation of Emotional Reactivity and regulation to childhood stuttering . Journal of communication Disorders, 39 (6), 402-423.

59- Lewis, B, Freebairn, L, Hansen, A, Stein, C, Shriberg, L, Lyngar, S \&Taylor, H (2006): Dimensions of Early speech sound Disorders, A Factor Analytic study. Journal of communication Disorders, (39), 139-157.

60- Memisevic, H \& Hadzic, S (2013): The Relationship between Visual - Motor Integration and Articulation Disorders in Preschool Children, Journal of Occupational Therapy, School, \& Early Intervention, 6 (1) 23 - 30. 
61- Ratul.D, Satish. K, Tijender. K, JaiLal. D ( 2017 ) : Variety of speech and language disorders reporting at a tertiary care hospital in Malwa belt of Punjab, India , Clinical Epidemiology and Global Health, In Press, Corrected Proof, Available online 9 January 2017.

62- Steentratnt, F, (2007): ls misrovasular Compression of the Vestibuleocochrar Nerve a case of unilateral hearing loss? Annals otology , Rhinogy \& Larynqogy,11,(4),248-252.

63- Taylor, A. \& Sandoval, K. (2004): preschoolers with phonological and language Disorders, Different Linguistic Domains, Journal of language Speech and Hearing Services in the Schools, (25), 215-234.

64- Tomic,G. ,Stojanovic,M. Palovic ,A.(2009): Speech and language disorders secondary to diffuse sub cortical vascular lesions, neurolinguistic and acoustic analysis :A case report, Journal of the Neurological Sciences,(283) ,163-169.

65- Uwiera,T\& Dealarcon ,A, (2009): hearing loss progress and contra lateral involvement in children with unilateral sensor neural hearing loss ,annals of otology ,Rhinology and Laryngologist ,118, (11), 781-785.

66- Vanhoudta, I, Thomasb, G, Wellensa, W, (2008): The background biopsysocial status of teachers with voice problem, Journal of psychosomatic Research, 65, 371-380.

67- Wurtele. S. K. (1992): Comparison of teather vs parents as instructors of a personal safety program for preschoolers, child Abuse and Neglect: the international journal, 16 (1), pp. $127-137$.

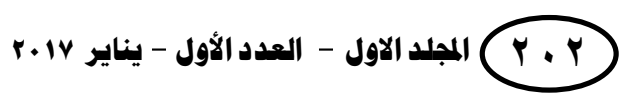

